\title{
Supergene minerals at the Huber stock and Schnöd stock deposits, Krásno ore district, the Slavkovský les area, Czech Republic
}

\author{
Supergení minerály ložisek Huberova a Schnödova pně, rudní revír Krásno, \\ Slavkovský les, Česká republika
}
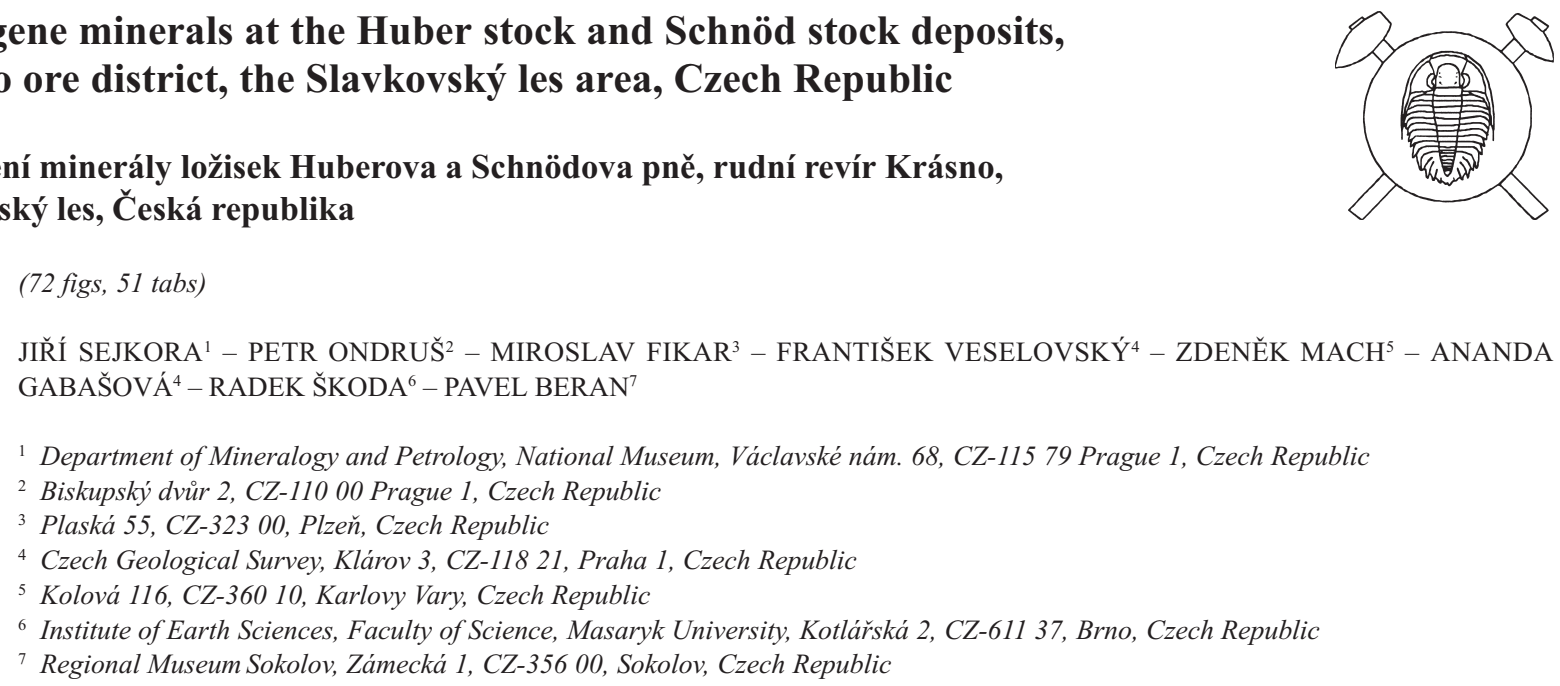

This paper presents results of study of supergene minerals occuring at the Huber stock and Schnöd stock in the Krásno Sn-W ore district near Horní Slavkov (Slavkovský les area, Czech Republic). The mineralogical research is based on X-ray powder diffraction, electron microprobe analyses, optical and electron microscopy. The paper includes encyclopaedia-type presentation of the identified mineral species. The role of late hydrothermal, supergene, sub-recent and recent processes in the formation of minerals and their associations is discussed.

Key words: supergene minerals; mineralogy; greisen; Huber stock; Schnöd stock; Krásno near Horní Slavkov; Slavkovský les area; western Bohemia; Czech Republic

\section{Introduction}

Studies of granite-related mineral deposits, such as greisen and vein types at Krásno near Horní Slavkov ore district were focused in most cases on their geological, structural, bulk mineralogical-geochemical and economic aspects. This approach was dictated by the purpose of a given project, whereas detailed mineral characterization was commonly limited to the mineral associations of practical use only. In our paper attention is drawn to the precise mineralogical investigation of the supergene mineralization, which has been insufficiently explored in this ore district.

Prolonged mineralogical studies taking place from about 1975 to 2005 were focused on supergene mineralization developed in the Huber and Schnöd stocks, their perimeters and the associated vein structures, i.e., the cluster of quartz veins trending NE-SW, corresponding to the Gellnauer vein system. The geological situation of this ore district is characterized in the accompanying paper (Beran - Sejkora 2006), presented in this issue.

The supergene mineralization in quartz veinlets and greisens of the Huber stock is well exposed in the open pit. The Huber open pit was exposed in the period 19731976 at the place of a collapsed medieval underground mining. Later on, the Huber open pit was again operated in 1984 and the exploitation terminated in 1987 (Fig. 1). At present the Huber open pit is gradually filled by material spontaneously released from sliding walls of the pit (Fig. 2). Entrance into the pit is prohibited due to collapse of old (and relatively modern) underground workings and permanent danger of caving-in of the floor and walls.
Additional occurrences of supergene mineralization have been found at the $4^{\text {th }}$ and $5^{\text {th }}$ level of the Huber stock, which were exposed by tunnels from the Stannum mine. This mine also provided access to the Schnöd stock, with occurrences of this mineralization at the VII th and VIII ${ }^{\text {th }}$ levels. After termination of mining in the Stannum mine in 1991, the ore district was flooded. Material bearing supergene mineralization also occurred in collapsed medieval underground mining sites at the Schnöd stock (Fig. 3), but these places are inaccessible due to filling the caved-in structure by refuse material. Some material occurs at relics of old dumps in proximity of the Huber stock, in particular the dump near the former ventilation shaft No. 2 (Fig. 4).

\section{Methods of mineral identification}

The surface morphology of samples was studied with the optical microscope Nikon SMZ1500 in combination with the digital camera Nikon DXM1200F, used for photography in incandescent light. Detailes of surface morphology were studied in secondary electron images using the scanning electron microscopes Jeol JSM T-20 (Z. Mach, Institute of Research of Fine Ceramics, Karlovy Vary), Tesla BS340 (A. Gabašová, Czech Geological Survey, Prague) and Jeol JSM-6380 (J. Sejkora and J. Plášil, Faculty of Science, Charles University, Prague).

The X-ray powder diffraction analysis was used for identification of minerals. To minimize complicated shape of background due to classic glass sample holder, the samples studied were placed on the surface of flat silicon wafer from alcoholic suspension. Step-scanned powder diffraction data were collected using Philips X'Pert 


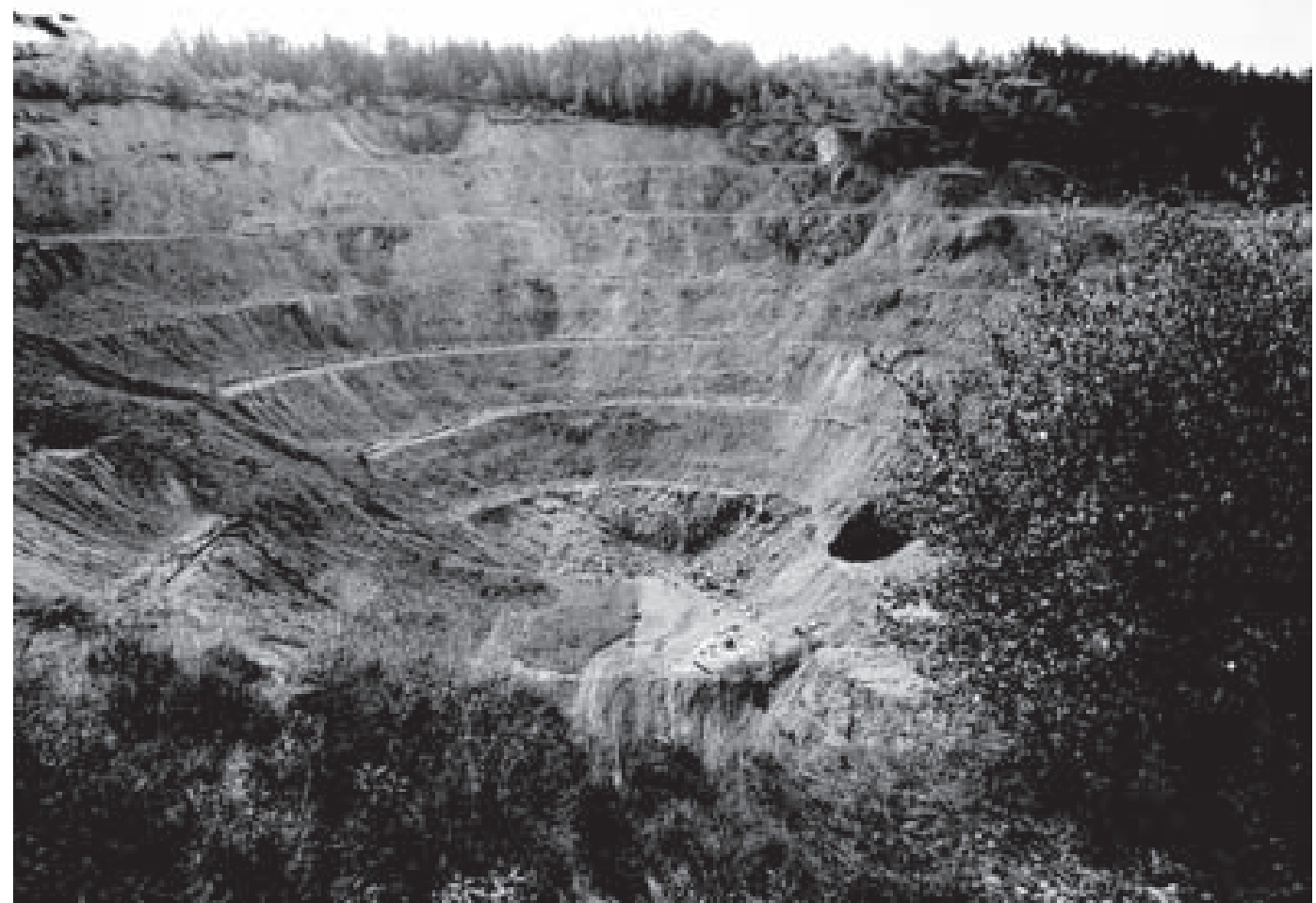

Fig. 1 View of the Huber open pit, Krásno, situation in 1987 (photo by P. Beran)
MPD diffractometer with a metallo-ceramic copper tube operated at high-voltage of $40 \mathrm{kV}$ and tube current of 40 A. A graphite secondary monochromator was used to produce $\mathrm{CuK} \alpha_{1} \alpha_{2}$ radiation; and HZG4-AREM/Seifert diffractometer with a copper tube was operated at highvoltage $50 \mathrm{kV}$ and tube current of $40 \mathrm{~mA}$. The results were processed using X-ray analysis software ZDS for DOS (Ondruš 1993), Bede ZDS Search/Match ver. 4.5 (Ondruš - Skála 1997); unit-cell parameters were refined by the program of Burnham (1962) and by the program FullProf (Rodríguez - Carvajal 2005).

For qualitative chemical analysis we used energy dispersion analyser Tracor-Northern (R. Rybka, Czech Geological Survey, Prague) and emission spectral analysis (E. Mrázová, Czech Geological Survey, Prague). Chemical composition of selected mineral specimens was analyzed using electron microprobe JXA 50A, ZAF correction method by Philibert (1963). The analyzer was operated at $20 \mathrm{KV}$ and $2 \cdot 10^{-8}-3 \cdot 10^{-8} \mathrm{~A}$ and depending on the elements analyzed. Standards included native metals and natural minerals.

Majority of quantitative chemical data were collected with the electron microprobe Cameca SX 100 (J. Sejkora and R. Škoda, Joint laboratory of Masaryk University and Czech Geological Survey, Brno). Studied samples were mounted into the epoxide resin discs and polished. The polished surfaces were coated with carbon layer $250 \AA$ thick. Wavelength dispersion mode and operating voltage of $15 \mathrm{kV}$ were used in all analyses. The beam cur- rent and diameter were adjusted to stability of analyzed phases under the electron beam. Stable phases were analyzed using $20 \mathrm{nA}$ current and $2 \mu \mathrm{m}$ beam diameter. Less stable and highly hydrated minerals were analyzed using 10-4 nA and 10-30 $\mu \mathrm{m}$ beam diameter. For smaller aggregates $(<10 \mu \mathrm{m})$ of unstable minerals the beam diameter was as large as possible and the applied beam current was only $1-2 \mathrm{nA}$. The sequence of analyzed elements was adjusted to particular composition of the analyzed mineral. Volatile and major elements were analyzed first, followed by stable, minor and trace elements. Elevated analytic totals of minerals containing a large amount of hydroxyl group or molecular water are generally caused by two factors: a) water evaporation under high vacuum conditions, well documented by collapsed crystals; b) water evaporation due to heating of the analyzed spot by electron beam. The dehydrated domain is seen as a notably brighter spot in backscattered electron images. Lower analytical totals for some samples are primarily caused by their porous nature or by poorly polished surface of soft or cryptocrystalline minerals.

In order to minimize peak overlapping the following analytic lines and crystals were selected: K $\alpha$ lines: F (PC1, fluorapatite/topaz), Mg (TAP, forsterite), Na (TAP, albite), Al (TAP, sanidine), As (TAP, InAs), $\mathrm{Si}$ (TAP, sanidine), $\mathrm{Cu}$ (TAP, dioptase), K (PET, sanidine), P (PET, fluorapatite) Ca (PET, andradite), S (PET, barite), Ti (PET, TiO), $\mathrm{Cl}$ (PET, vanadinite), Fe (LIF, andradite), Mn (LIF, rhodonite), Ni (LIF, NiO), Zn (LIF, 
$\mathrm{ZnO})$; L $\alpha$ lines: Y (TAP, YAG), Sr (PET, $\mathrm{SrSO}_{4}$ ), $\mathrm{La}\left(\mathrm{PET}, \mathrm{LaB}_{6}\right), \mathrm{Ce}\left(\mathrm{PET}, \mathrm{CeAl}_{2}\right), \mathrm{Sm}\left(\mathrm{LIF}, \mathrm{SmF}_{3}\right)$; LB lines: $\mathrm{Ba}$ (PET, benitoite), $\mathrm{Pr}$ (LIF, $\mathrm{PrF}_{3}$ ), $\mathrm{Nd}$ (LIF, $\left.\mathrm{NdF}_{3}\right) ; \mathrm{M} \alpha$ lines: Th (PET, $\left.\mathrm{ThO}_{2}\right), \mathrm{Pb}$ (PET, vanadinite); Mß lines: Bi (PET, metallic Bi), U (PET, metallic U).
Peak counting times (CT) were 10 to $20 \mathrm{~s}$ for main elements and 30 to $60 \mathrm{~s}$ for minor and traces elements. CT for each background was 1 of peak time. In case the background was measured only one side of the peak, the counting time was the same as counting on the peak. As

Fig. 2 View of the Huber open pit, Krásno, situation in 2003 (photo by J. Sejkora)

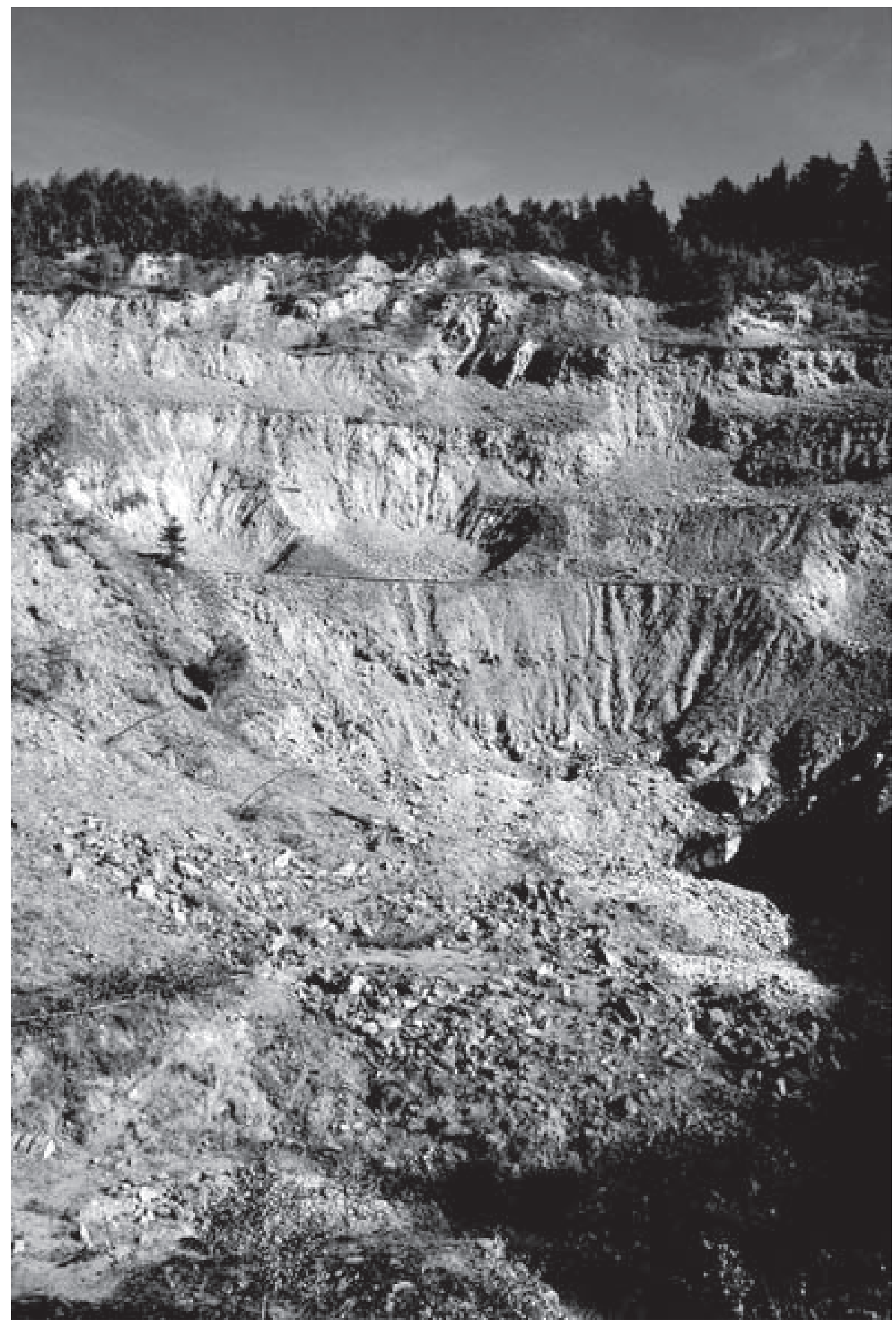




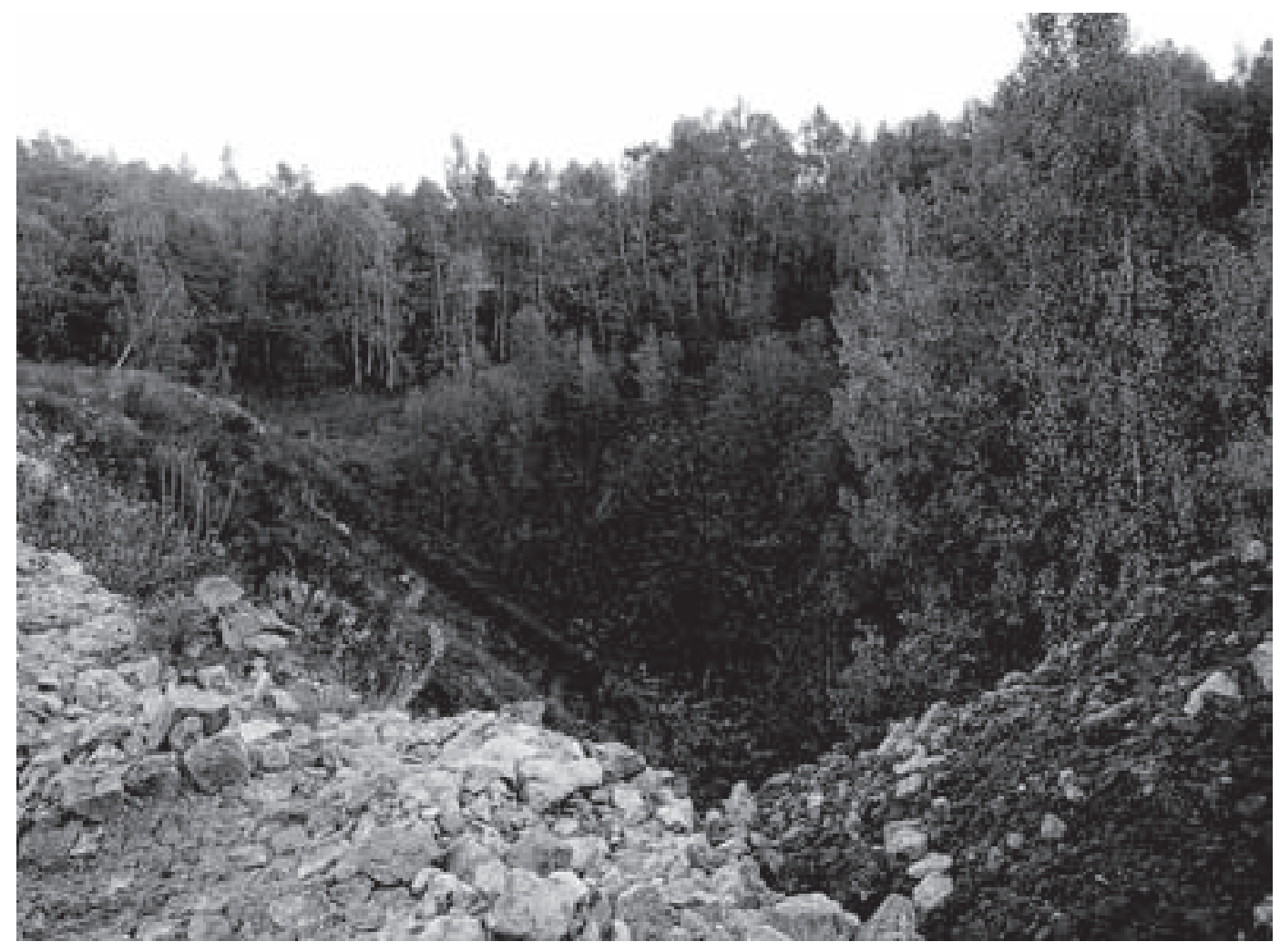

Fig. 3 View of the collapse pit at the Schnöd stock, Krásno. Situation before filling of the pit by refuse material (photo by P. Ondruš).

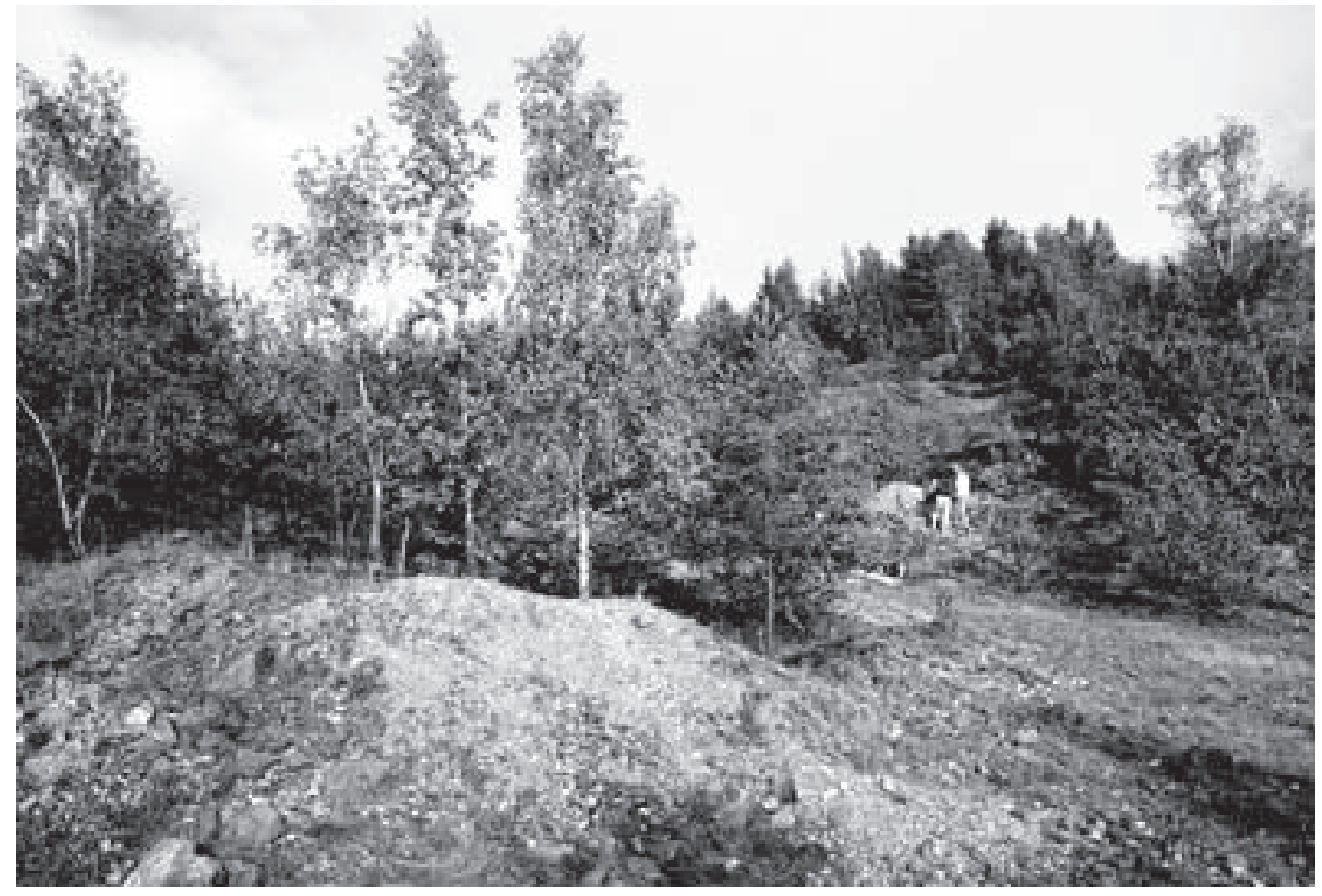

Fig. 4 Dumps from the period of historical mining around the $\mathrm{Hu}-$ ber open pit, Krásno (photo by J. Sejkora, 2002). 
far as possible, elements present in minor and trace abundances were measured with highly sensitive crystals LPET a LLIF. Raw intensities were converted to the concentrations using automatic PAP (Pouchou - Pichoir 1985) matrix correction software package.

\section{Review of identified mineral species}

\section{Adamite $\mathrm{Zn}_{2}\left(\mathrm{AsO}_{4}\right)(\mathrm{OH})$}

Adamite has been identified in samples from the $5^{\text {th }}$ level of the Huber shaft and also from the floor of the open pit in the Huber stock. It is bound to proximity of weathered primary sulphides (sphalerite, chalcopyrite etc.) as aggregates of minute bipyramidal to acicular crystals, up to $2 \mathrm{~mm}$ long. Crystals of the olivenite-adamite series occur in association with libethenite, chalcanthite, limonite and fluorapatite. Adamite aggregates show a vitreous lustre and light yellow green colour. The mineral was identified by X-ray powder diffraction and semiquantitative microprobe analyses, which show that the $\mathrm{Zn} / \mathrm{Cu}$ ratio in studied samples is variable with regard to the substitution series olivenite - adamite (Braithwaite 1983).

\section{Alunite $\mathrm{KAl}_{3}\left(\mathrm{SO}_{4}\right)_{2}(\mathrm{OH})_{6}$}

Alunite has been found as coating in vugs of quartz gangue in association with hübnerite, in samples from medieval dumps behind the ventilation shaft No. 2. It forms tiny crystals up to $0.2 \mathrm{~mm}$ long, of a deep brown colour and vitreous lustre. Alunite was identified by $\mathrm{X}$-ray powder diffraction.

\section{Antlerite $\mathrm{Cu}_{3}\left(\mathrm{SO}_{4}\right)(\mathrm{OH})_{4}$}

Rare antlerite occurs as light green earthy and finely crystalline coatings or a fill of cavities in quartz with decomposed chalcopyrite, cassiterite and arsenopyrite at the Huber open pit. The weathered portions of the vein are up to 2 by $5 \mathrm{~cm}$ in size. Antlerite is intergrown with unidentified yellow brown Fe oxy-hydroxides and encloses relics of weathered cassiterite. The mineral was identified by X-ray powder diffraction. The refined unit-cell parameters (Table 1) are in good agreement with the data published for this mineral.

Table 1 Unit-cell parameters of antlerite (for orthorhombic space group Pnma)

\begin{tabular}{|l|ccc|}
\hline & this paper & Hawthorne et al. (1989) & Vilminot et al. $(2003)$ \\
\hline $\mathrm{a}[\AA]$ & $8.2598(8)$ & $8.244(2)$ & $8.289(1)$ \\
$\mathrm{b}[\AA]$ & $6.0536(5)$ & $6.043(1)$ & $6.079(1)$ \\
$\mathrm{c}[\AA]$ & $12.019(1)$ & $11.987(3)$ & $12.057(1)$ \\
$\mathrm{V}\left[\AA^{3}\right]$ & 600.97 & 597.17 & 607.54 \\
\hline
\end{tabular}

\section{Arseniosiderite $\mathrm{Ca}_{3} \mathrm{Fe}^{3+}{ }_{4}\left(\mathrm{AsO}_{4}\right)_{4}(\mathrm{OH})_{6} \cdot 3 \mathrm{H}_{2} \mathrm{O}$}

Arseniosiderite occurs as red brown hard crusts with velvety surface in cavities in quartz at the Huber open pit. It has a poorly defined radiating structure of aggregates. Arseniosiderite formed as a late product of weathering of arsenopyrite and by decomposition of older iron arsenates (scorodite and pharmacosiderite). It has also been found as thin prismatic brown aggregates on old dumps around the ventilation shaft No. 2. Arseniosiderite was identified by X-ray powder diffraction method. Its refined unit-cell parameters (Table 2) are in good agreement with the published data.

Table 2 Unit-cell parameters of arseniosiderite (for monoclinic space group $A 2 / a$ )

\begin{tabular}{|l|cc|}
\hline & $\begin{array}{c}\text { Krásno } \\
\text { this paper }\end{array}$ & $\begin{array}{c}\text { Mapimi, Mexico } \\
\text { Moore - Ito (1974) }\end{array}$ \\
\hline $\mathrm{a}[\AA]$ & $17.712(2)$ & $17.76(4)$ \\
$\mathrm{b}[\AA]$ & $19.533(2)$ & $19.53(1)$ \\
$\mathrm{c}[\AA]$ & $11.3270(9)$ & $11.30(1)$ \\
$\mathrm{B}\left[{ }^{\circ}\right]$ & $96.03(1)$ & 96.0 \\
$\mathrm{~V}\left[\AA^{3}\right]$ & 3897.1 & 3897.9 \\
\hline
\end{tabular}

Aurichalcite $(\mathrm{Zn}, \mathrm{Cu})_{5}\left(\mathrm{CO}_{3}\right)_{2}(\mathrm{OH})_{6}$

Aurichalcite has been identified as minute blue green acicular crystals, up to $2 \mathrm{~mm}$ long, on fractures and in vugs in quartz. The samples of quartz gangue with aurichalcite originate from old dumps between the Huber open pit and the ventilation shaft No. 2 .

Aurichalcite was identified by X-ray powder diffraction.

\section{Azurite $\mathrm{Cu}_{3}\left(\mathrm{CO}_{3}\right)_{2}(\mathrm{OH})_{2}$}

Azurite, first mentioned from this locality by Zepharovich (1857) and Glückselig (1862), was recorded later by number of other mineralogists. Korbel (1991) described rare azurite as minute blue crystals and compact aggregates from the Huber open pit. Spectral analysis, powder diffraction data and unit-cell parameters are given in this paper.

Recently, azurite has been found at several places underground, including the $4^{\text {th }}$ and $5^{\text {th }}$ level at the Huber stock and VII ${ }^{\text {th }}$ and VIII ${ }^{\text {th }}$ level at the Schnöd stock as coatings, small compact masses and rare crystals, up to $2 \mathrm{~mm}$ in size. It forms rare powdery coatings and very tiny crystal aggregates on gangue fractures at the Huber open pit. Cassiterite, arsenopyrite, chalcopyrite and bornite were observed in association with azurite. It was identified by X-ray powder diffraction data; its refined unit-cell parameters (Table 3 ) are in good agreement with the published data. 
Table 3 Unit-cell parameters of azurite (for monoclinic space group $P 2 / c)$

\begin{tabular}{|l|ccc|}
\hline & $\begin{array}{c}\text { Huber stock } \\
\text { this paper }\end{array}$ & $\begin{array}{c}\text { Huber stock } \\
\text { Korbel }(1991)\end{array}$ & $\begin{array}{c}- \\
\text { Zigan }- \text { Schuster }(1972)\end{array}$ \\
\hline $\mathrm{a}[\AA]$ & $5.021(1)$ & $5.010(3)$ & $5.0109(5)$ \\
$\mathrm{b}[\AA]$ & $5.834(4)$ & $5.836(4)$ & $5.8485(6)$ \\
$\mathrm{c}[\AA]$ & $10.358(3)$ & $10.375(1)$ & $10.345(2)$ \\
$ß\left[^{\circ}\right]$ & $92.44(2)$ & $92.22(7)$ & $92.43(3)$ \\
$\mathrm{V}\left[\AA^{3}\right]$ & 303.14 & 303.12 & 302.9 \\
\hline
\end{tabular}

\section{Betpakdalite $\mathrm{Ca}_{2} \mathrm{MgFe}^{3+}{ }_{3} \mathrm{As}^{5+}{ }_{2} \mathrm{Mo}^{6+}{ }_{8} \mathrm{O}_{36}(\mathrm{OH})$. 23H $\mathrm{O}_{2}$}

This mineral has been found only in several samples along fractures in greisen from the Huber stock. It forms striking yellow rims around partly weathered aggregates of molybdenite, in close proximity to corroded arsenopyrite and chalcopyrite. Betpakdalite is typically accompanied by clay minerals and it was identified by X-ray powder diffraction.

\section{Bindheimite $\mathrm{Pb}_{2} \mathrm{Sb}_{2} \mathrm{O}_{6}(\mathrm{O}, \mathrm{OH})$}

Bindheimite was found only rarely as light yellow brown, fine-grained or fibrous mineral filling cavity, about $3 \mathrm{~cm}$ in size, in quartz gangue in the Huber open pit. It was identified by X-ray powder diffraction and its refined unit-cell parameters (Table 4) correspond well to the published data.

Table 4 Unit-cell parameters of bindheimite (for cubic space group $F d-3 m)$

\begin{tabular}{|l|cc|}
\hline & $\begin{array}{c}\text { Huber stock } \\
\text { this paper }\end{array}$ & Natta - Baccaredda (1933) \\
\hline $\mathrm{a}[\AA]$ & $10.416(1)$ & 10.44 \\
$\mathrm{~V}\left[\AA^{3}\right]$ & 1130.1 & 1137.9 \\
\hline
\end{tabular}

\section{Bismite $\mathrm{Bi}_{2} \mathrm{O}_{3}$}

In the old literature the name bismite was used for unadequately identified yellow bismuth ochres (see review by Kratochvíl 1963). Mach - Korbel (1990) described bismite as bright yellow powdery to botryoidal aggregates in cavities of quartz gangue. The mentioned new bismite occurrence at the level of $455 \mathrm{~m}$ a.s.1. in the $\mathrm{Hu}-$ ber shaft, is represented by grey rims around grains of native bismuth or around bismuthinite needles; however, no analytical data were given. Beran (1999) doubted this identification, considering this material to be a mixture of presingerite, bismutite and zavaritskite.

In the course of the present study rare bismite has been identified as a component of grey pseudomorphs after native bismuth grains in quartz gangue from the Huber open pit. Bismite forms irregular aggregates, up to $300 \mu \mathrm{m}$ in size, which enclose abundant relics of native
Bi (Fig. 5), and are intensively replaced by bismutite. The mineral was identified by quantitative microprobe analysis, it corresponds to nearly pure $\mathrm{Bi}_{2} \mathrm{O}_{3}$ with minor F content below 0.3 wt. $\%$.

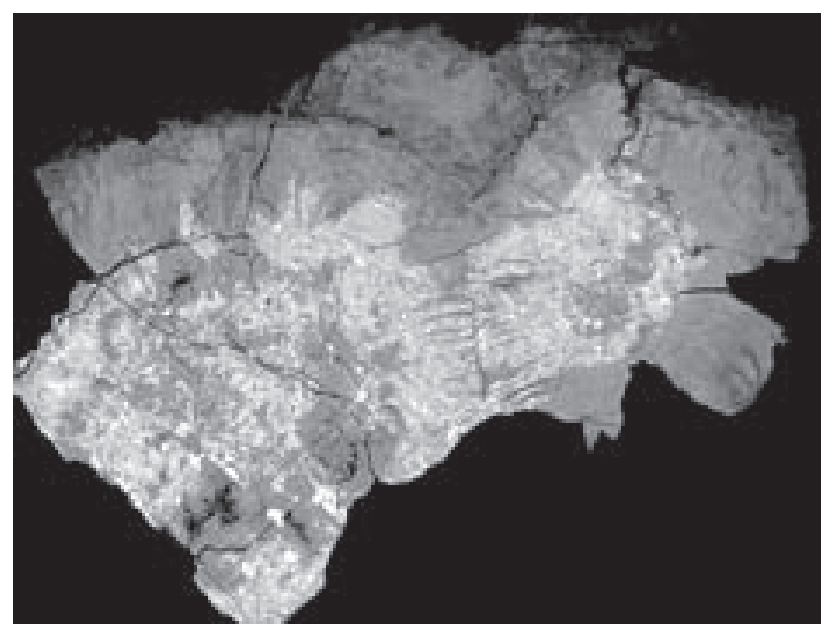

Fig. 5 Bismite aggregates (light) with abundant relics of native $\mathrm{Bi}$ (white), intensively replaced by bismutite (dark grey). Huber open pit, Krásno. Width of the BSE photo $1.5 \mathrm{~mm}$. Cameca SX100 (J. Sejkora, R. Škoda).

\section{Bismutite (BiO) $)_{2} \mathrm{CO}_{3}$}

It has been found at several places through the whole profile of the Huber stock. The most interesting samples come from greisen and from quartz veinlets at the $4^{\text {th }}$ level of the Huber mine; it was also abundant at numerous places in the Huber open pit. Bismutite occurs as a part of grey black aggregates, up to $5 \mathrm{~mm}$ long, with a greasy to semi-metallic lustre, intergrown in white coarse-grained quartz. These aggregates represent pseudomorphs after native $\mathrm{Bi}$, which is locally preserved in central parts of the aggregates. X-ray powder diffraction and microprobe analyses indicate that bismutite is intergrown with zavaritskite, preisingerite and other minerals. The outer portions of these aggregates are often replaced by later (sub-recent) russellite. Owing to this situation, only diffraction maxima free of coincidence were used for refinement of unit-cell parameters. The parameters obtained (Table 5) are in good agreement with the published data.

Table 5 Unit-cell parameters of bismutite (for orthorhombic space group Imm2)

\begin{tabular}{|l|ccr|}
\hline & $\begin{array}{c}\text { Huber stock } \\
\text { this paper }\end{array}$ & $\begin{array}{c}\text { Huber stock } \\
\text { Sejkora }(1992)\end{array}$ & $\begin{array}{c}- \\
\text { Grice }(2002)\end{array}$ \\
\hline $\mathrm{a}[\AA]$ & $3.878(7)$ & $3.876(4)$ & $3.865(2)$ \\
$\mathrm{b}[\AA]$ & $3.878(7)$ & $3.876(4)$ & $3.862(2)$ \\
$\mathrm{c}[\AA]$ & $13.65(3)$ & $13.73(5)$ & $13.675(6)$ \\
$\mathrm{V}\left[\AA^{3}\right]$ & $205.3(5)$ & $206.2(5)$ & 204.12 \\
\hline
\end{tabular}




\section{Bismutoferrite $\mathrm{BiFe}^{3+}{ }_{2}\left(\mathrm{SiO}_{4}\right)_{2}(\mathrm{OH})$}

Very rare bismutoferrite has been observed at the $5^{\text {th }}$ level of the Huber stock. It forms grey yellow-green earthy aggregates, filling small cavities in quartz. The mineral identified by X-ray powder diffraction is associated with cassiterite, fluorite, native bismuth, varlamoffite, clay minerals and zinnwaldite.

\section{Brochantite $\mathrm{Cu}_{4}\left(\mathrm{SO}_{4}\right)(\mathrm{OH})_{6}$}

Korbel (1991) presented the first well-evidenced description of brochantite, as light blue-green crystalline crusts with botryoidal surface on the weathered tennantite and as blue-green clay-like aggregates. He presented spectral analysis, X-ray diffraction pattern and unitcell parameters.

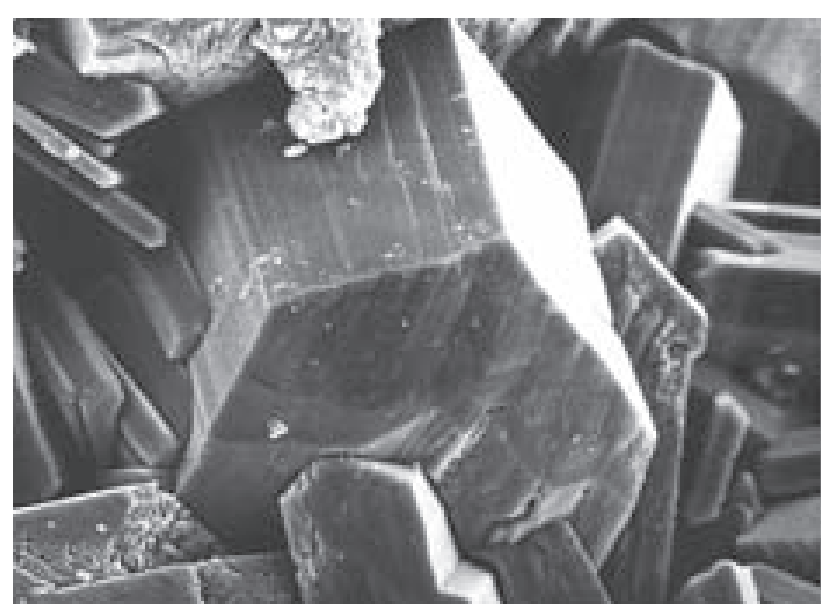

Fig. 6 Prismatic crystals of brochantite. Huber open pit, Krásno. Width of SE photo $50 \mu \mathrm{m}$; SEM Jeol JSM T-20 (Z. Mach).

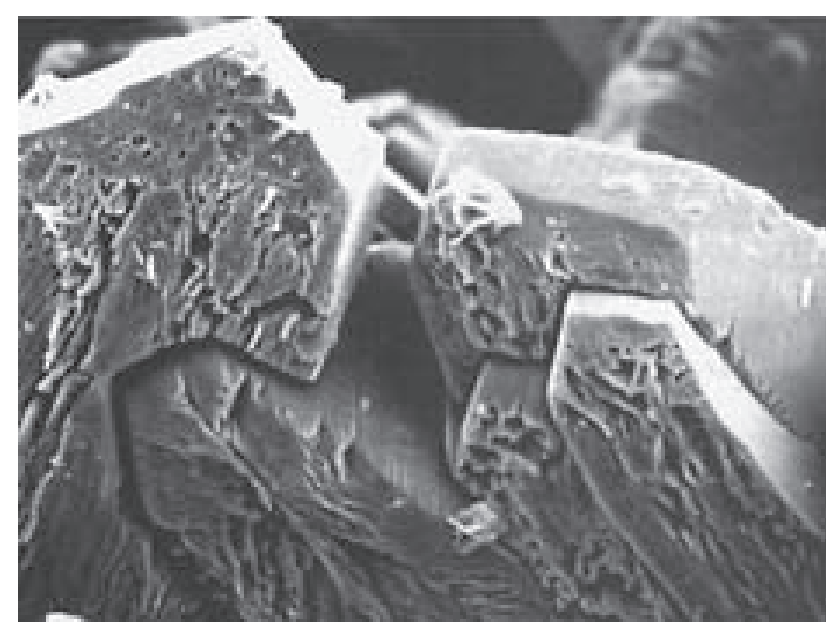

Fig. 7 Brochantite crystals showing recent corrosion features. Huber open pit, Krásno; width of SE photo $125 \mu \mathrm{m}$; SEM Jeol JSM T-20 (Z. Mach).
The studied brochantite originates from the Huber open pit. It is one of the most common supergene minerals together with scorodite and pharmacosiderite. It composes coatings, efflorescence and powdery crusts near weathered sulphides (chalcopyrite, pyrite, arsenopyrite, covellite etc.). Brochantite aggregates are composed of tiny tabular crystals up to $0.2 \mathrm{~mm}$ long, with well-defined (Fig. 6) or corroded (Fig. 7) crystal-faces. It has green to dark green colour, which turns to black if brochantite contains products of decomposition of the primary sulphides. Brochantite formed as one of the youngest minerals under supergene conditions from relatively acid solutions (Povondra - ̌̌ídkošil 1980).

Brochantite was identified by X-ray powder diffraction data. The refined unit-cell parameters correspond to the data published for this mineral (Table 6). The chemical analysis of brochantite (Table 7) yields the formula $\mathrm{Cu}_{3.99}\left(\mathrm{SO}_{4}\right)_{1.01}(\mathrm{OH})_{5.96}$ calculated on the basis of $10(\mathrm{O}, \mathrm{OH})$.

Table 6 Unit-cell parameters of brochantite (for monoclinic space group $P 2 / a)$

\begin{tabular}{|l|cc|}
\hline & $\begin{array}{c}\text { Huber stock } \\
\text { this paper }\end{array}$ & \begin{tabular}{c} 
Merlino et al. $(2003)$ \\
\hline $\mathrm{a}[\AA]$
\end{tabular} \\
$\mathrm{b}[\AA]$ & $13.110(9)$ & $13.140(2)$ \\
$\mathrm{c}[\AA]$ & $9.853(5)$ & $9.863(2)$ \\
$\mathrm{B}\left[{ }^{\circ}\right]$ & $6.015(3)$ & $6.024(1)$ \\
$\mathrm{V}\left[\AA^{3}\right]$ & $103.37(4)$ & $103.16(3)$ \\
\hline
\end{tabular}

Table 7 Chemical composition of brochantite

\begin{tabular}{|l|cc|}
\hline & $* 1$ & $* 2$ \\
\hline $\mathrm{CuO}$ & 69.40 & 70.35 \\
$\mathrm{SO}_{3}$ & 17.70 & 17.70 \\
$\mathrm{H}_{2} \mathrm{O}^{*}$ & 11.87 & 11.95 \\
total & 98.97 & 100.00 \\
\hline
\end{tabular}

* $\mathrm{H}_{2} \mathrm{O}$ content calculated from stoichiometry, using the ideal formula $\mathrm{Cu}_{4}\left(\mathrm{SO}_{4}\right)(\mathrm{OH})_{6}$ and charge balance.

*1 Huber stock, Krásno

*2 composition calculated from ideal formula $\mathrm{Cu}_{4}\left(\mathrm{SO}_{4}\right)(\mathrm{OH})_{6}$

\section{Cannonite $\mathrm{Bi}_{2} \mathrm{O}\left(\mathrm{SO}_{4}\right)$}

Cannonite was identified on several samples from the Huber open pit as pseudomorphs after acicular crystals of bismuthinite and emplectite (Fig. 8). These pseudomorphs are light brown, beige to white in colour, very brittle and soft. Cannonite covers bismuthinite and emplectite aggregates, which are often completely replaced (Fig. 9). The surface of the aggregates shows radiating, parallel or randomly oriented tabular crystals grading to platy acicular crystals $10-20 \mu \mathrm{m}$ long (Figs 10, 11). The cavities carrying cannonite are 1 by $2 \mathrm{~cm}$ in size 


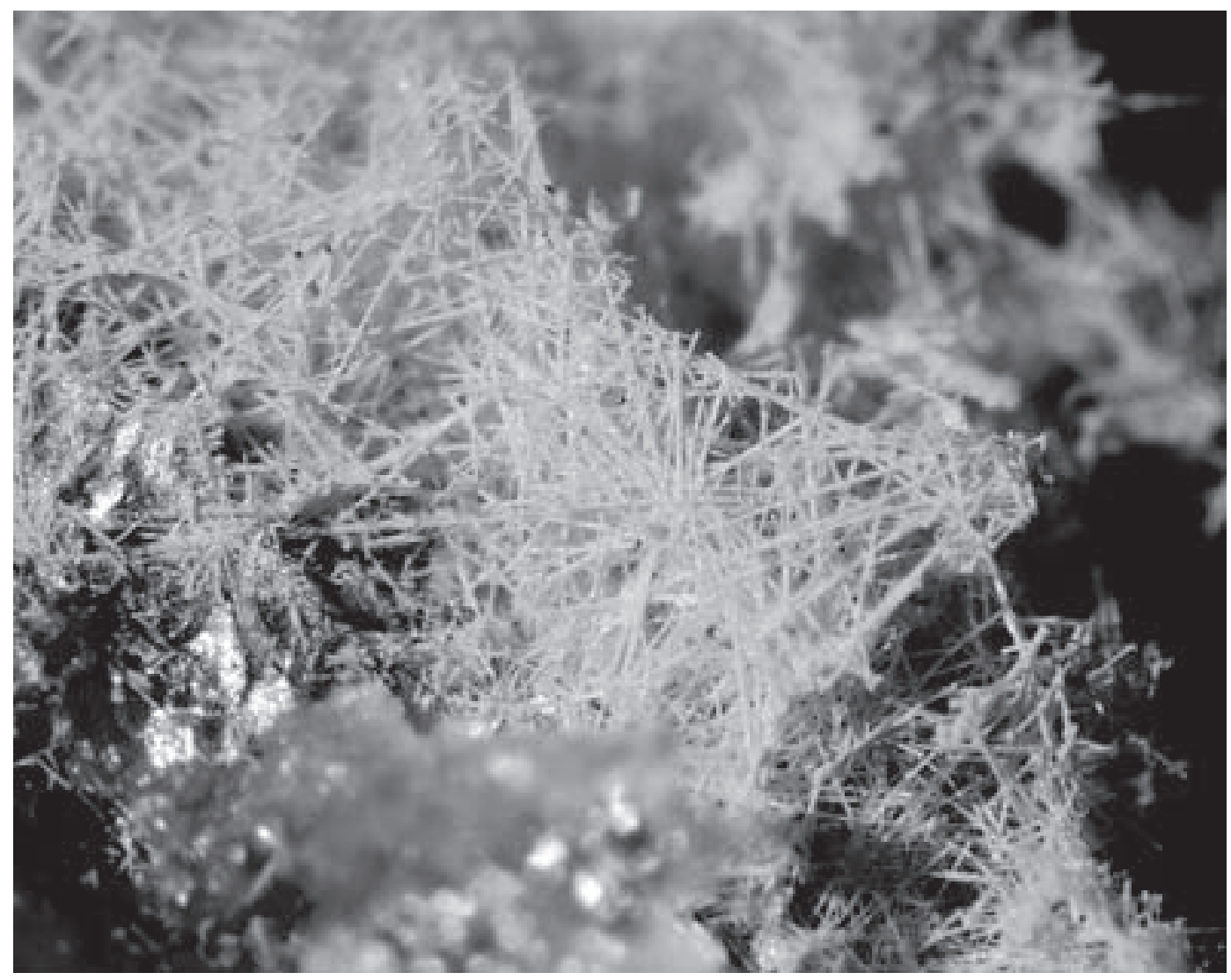

Fig. 8 Cannonite aggregates constituting pseudomorphs after bismuthinite crystals. Huber open pit, Krásno. Width of photo $2 \mathrm{~mm}$; Nicon SMZ 1500 microphotography (J. \& E. Sejkora).

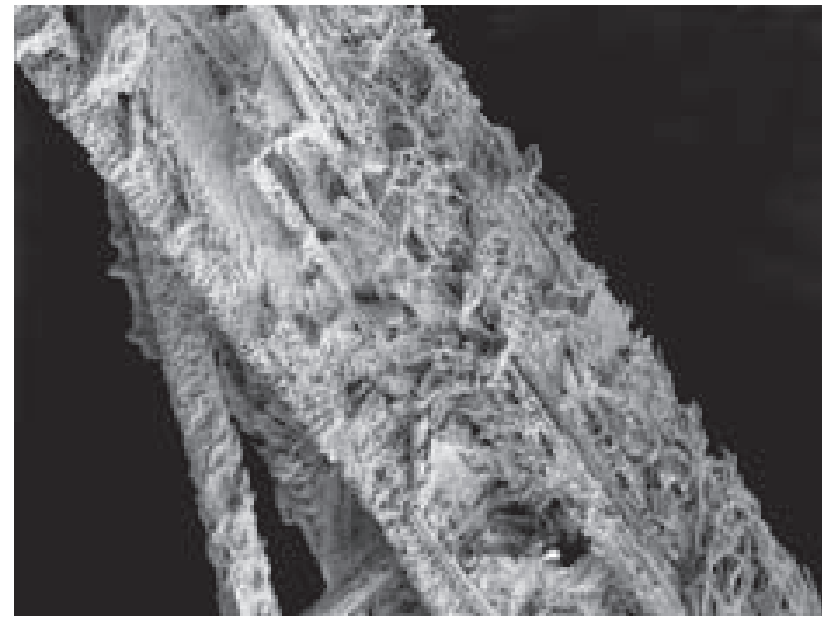

Fig. 9 Acicular bismuthinite crystals replaced by cannonite crystalline aggregate. Huber open pit, Krásno; width of SE photo $400 \mu \mathrm{m}$; SEM Tesla 320 (A. Gabašová).

and no other Bi minerals have been observed in this association.

$\mathrm{X}$-ray powder diffraction pattern of cannonite (Table 8) corresponds to the data published by Stanley et al. (1992), but the measured chart contains numerous diffraction maxima not previously reported for this min-

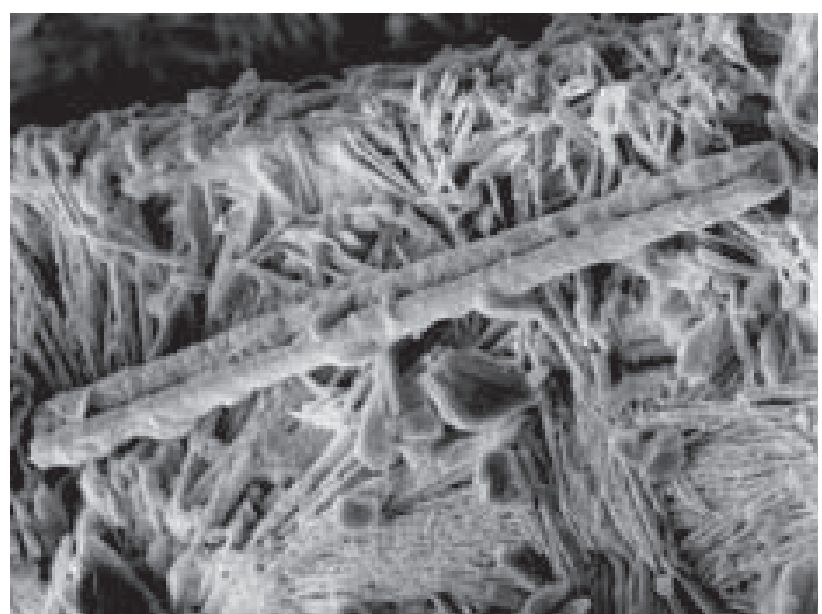

Fig. 10 Elongated tabular crystals of cannonite. Huber open pit, Krásno; width of SE photo $80 \mu \mathrm{m}$; SEM Tesla 320 (A. Gabašová).

eral. The refined unit-cell parameters (Table 9) correspond to the published data. Semiquantitative WD microprobe analysis confirmed $\mathrm{Bi}$ and $\mathrm{S}$ as the major elements. It was not possible to obtain quantitative chemical analysis owing to its instability under the electron beam. 
Table 8 X-ray powder diffraction pattern of cannonite.

\begin{tabular}{|c|c|c|c|c|c|c|c|c|c|c|c|c|c|c|}
\hline$I_{r e l}$ & $d$ & $h$ & $k$ & $l$ & $I$ & $d$ & $h$ & $k$ & $l$ & $I_{r e l}$ & $d$ & $h$ & $k$ & $l$ \\
\hline 18 & 7.282 & 1 & 0 & 0 & 7 & 2.2626 & 1 & 1 & 2 & 3 & 1.6873 & -3 & 2 & 3 \\
\hline 22 & 6.942 & 0 & 2 & 0 & 12 & 2.2377 & 1 & 5 & 1 & 4 & 1.6839 & -4 & 4 & 1 \\
\hline 27 & 6.449 & 1 & 1 & 0 & 12 & 2.2305 & -3 & 3 & 1 & 3 & 1.6749 & 3 & 6 & 0 \\
\hline 8 & 5.025 & 1 & 2 & 0 & 23 & 2.2079 & 2 & 5 & 0 & 2 & 1.6731 & 0 & 3 & 3 \\
\hline 6 & 5.019 & 0 & 1 & 1 & 16 & 2.2053 & 1 & 6 & 0 & 11 & 1.6609 & -1 & 4 & 3 \\
\hline 16 & 4.885 & -1 & 1 & 1 & 2 & 2.2014 & -2 & 5 & 1 & 9 & 1.6597 & 2 & 4 & 2 \\
\hline 12 & 4.254 & 0 & 2 & 1 & 10 & 2.1663 & -3 & 1 & 2 & 5 & 1.6517 & 0 & 8 & 1 \\
\hline 32 & 4.171 & -1 & 2 & 1 & 3 & 2.1270 & 0 & 4 & 2 & 4 & 1.6283 & -3 & 3 & 3 \\
\hline 17 & 3.906 & 1 & 3 & 0 & 4 & 2.1259 & 0 & 6 & 1 & 3 & 1.6269 & -1 & 7 & 2 \\
\hline 37 & 3.647 & 1 & 1 & 1 & 12 & 2.1025 & 2 & 4 & 1 & 2 & 1.6122 & 4 & 4 & 0 \\
\hline 23 & 3.641 & 2 & 0 & 0 & 9 & 2.0913 & -3 & 2 & 2 & 3 & 1.5862 & 2 & 7 & 1 \\
\hline 15 & 3.522 & 2 & 1 & 0 & 29 & 1.9892 & 3 & 4 & 0 & 3 & 1.5656 & 4 & 1 & 1 \\
\hline 14 & 3.509 & 0 & 3 & 1 & 17 & 1.9869 & -1 & 5 & 2 & 6 & 1.5646 & -3 & 7 & 1 \\
\hline 9 & 3.496 & -2 & 1 & 1 & 10 & 1.9819 & -3 & 3 & 2 & 8 & 1.5642 & -2 & 8 & 1 \\
\hline 86 & 3.471 & 0 & 4 & 0 & 3 & 1.9734 & 1 & 6 & 1 & 11 & 1.5633 & -1 & 5 & 3 \\
\hline 9 & 3.462 & -1 & 3 & 1 & 11 & 1.9637 & 3 & 1 & 1 & 8 & 1.5623 & 2 & 5 & 2 \\
\hline 61 & 3.319 & 1 & 2 & 1 & 9 & 1.9529 & 2 & 6 & 0 & 2 & 1.5565 & 3 & 1 & 2 \\
\hline 57 & 3.224 & 2 & 2 & 0 & 12 & 1.9484 & -2 & 6 & 1 & 3 & 1.5551 & -3 & 4 & 3 \\
\hline 73 & 3.204 & -2 & 2 & 1 & 9 & 1.9327 & 0 & 5 & 2 & 6 & 1.5359 & 3 & 7 & 0 \\
\hline 14 & 3.133 & 1 & 4 & 0 & 5 & 1.9142 & 2 & 5 & 1 & 4 & 1.5321 & 1 & 3 & 3 \\
\hline 100 & 2.927 & 1 & 3 & 1 & 7 & 1.9136 & 1 & 7 & 0 & 4 & 1.5225 & 4 & 5 & 0 \\
\hline 4 & 2.917 & 0 & 4 & 1 & 8 & 1.9133 & 1 & 4 & 2 & 5 & 1.5191 & -4 & 2 & 3 \\
\hline 5 & 2.890 & -1 & 4 & 1 & 10 & 1.9074 & -4 & 1 & 1 & 9 & 1.5139 & -4 & 5 & 2 \\
\hline 8 & 2.862 & 2 & 3 & 0 & 10 & 1.9073 & 3 & 2 & 1 & 3 & 1.5060 & 3 & 6 & 1 \\
\hline 20 & 2.847 & -2 & 3 & 1 & 2 & 1.9014 & -2 & 5 & 2 & 2 & 1.5024 & -5 & 0 & 2 \\
\hline 10 & 2.844 & -1 & 0 & 2 & 10 & 1.8898 & 2 & 0 & 2 & 8 & 1.49363 & -5 & 1 & 2 \\
\hline 33 & 2.787 & -1 & 1 & 2 & 11 & 1.8725 & 2 & 1 & 2 & 14 & 1.49157 & 4 & 3 & 1 \\
\hline 17 & 2.643 & 0 & 1 & 2 & 9 & 1.8611 & 0 & 7 & 1 & 8 & 1.48369 & 3 & 3 & 2 \\
\hline 5 & 2.609 & -2 & 0 & 2 & 12 & 1.8556 & -4 & 2 & 1 & 3 & 1.48293 & 0 & 9 & 1 \\
\hline 6 & 2.594 & 1 & 5 & 0 & 22 & 1.8275 & 3 & 5 & 0 & 2 & 1.48147 & -1 & 8 & 2 \\
\hline 6 & 2.564 & -2 & 1 & 2 & 4 & 1.8250 & -1 & 2 & 3 & 3 & 1.48017 & -4 & 6 & 1 \\
\hline 15 & 2.512 & 2 & 4 & 0 & 3 & 1.8234 & 2 & 2 & 2 & 11 & 1.45057 & 2 & 8 & 1 \\
\hline 7 & 2.510 & 0 & 2 & 2 & 3 & 1.8232 & 3 & 3 & 1 & 3 & 1.44847 & 5 & 1 & 0 \\
\hline 7 & 2.504 & -3 & 1 & 1 & 9 & 1.8205 & 4 & 0 & 0 & 2 & 1.43077 & 4 & 6 & 0 \\
\hline 2 & 2.503 & -2 & 4 & 1 & 2 & 1.8051 & 4 & 1 & 0 & 3 & 1.42223 & -2 & 0 & 4 \\
\hline 4 & 2.4696 & 2 & 2 & 1 & 12 & 1.7950 & -1 & 6 & 2 & 2 & 1.42050 & -4 & 4 & 3 \\
\hline 11 & 2.4678 & 0 & 5 & 1 & 19 & 1.7562 & 1 & 7 & 1 & 3 & 1.42039 & 2 & 9 & 0 \\
\hline 4 & 2.4513 & -1 & 5 & 1 & 9 & 1.7547 & 0 & 6 & 2 & 5 & 1.41483 & -2 & 1 & 4 \\
\hline 3 & 2.4424 & -2 & 2 & 2 & 6 & 1.7417 & 2 & 7 & 0 & 3 & 1.40615 & -5 & 4 & 1 \\
\hline 27 & 2.4274 & 3 & 0 & 0 & 8 & 1.7408 & 2 & 6 & 1 & 3 & 1.40502 & 2 & 2 & 3 \\
\hline 12 & 2.3911 & 3 & 1 & 0 & 13 & 1.7385 & -2 & 7 & 1 & 4 & 1.40089 & -1 & 1 & 4 \\
\hline 5 & 2.3901 & -3 & 2 & 1 & 12 & 1.7374 & 0 & 2 & 3 & 2 & 1.38834 & 0 & 10 & 0 \\
\hline 5 & 2.3268 & 0 & 3 & 2 & 7 & 1.7354 & 0 & 8 & 0 & 4 & 1.38395 & -3 & 0 & 4 \\
\hline 27 & 2.3139 & 0 & 6 & 0 & 8 & 1.7334 & -2 & 3 & 3 & 2 & 1.38384 & 1 & 8 & 2 \\
\hline 11 & 2.2947 & 2 & 3 & 1 & 8 & 1.7312 & -2 & 6 & 2 & 2 & 1.36816 & 2 & 7 & 2 \\
\hline 8 & 2.2932 & 1 & 0 & 2 & 4 & 1.7260 & -3 & 1 & 3 & 2 & 1.36391 & -5 & 1 & 3 \\
\hline 7 & 2.2913 & 3 & 2 & 0 & 3 & 1.7123 & -3 & 6 & 1 & 4 & 1.35603 & -1 & 9 & 2 \\
\hline
\end{tabular}

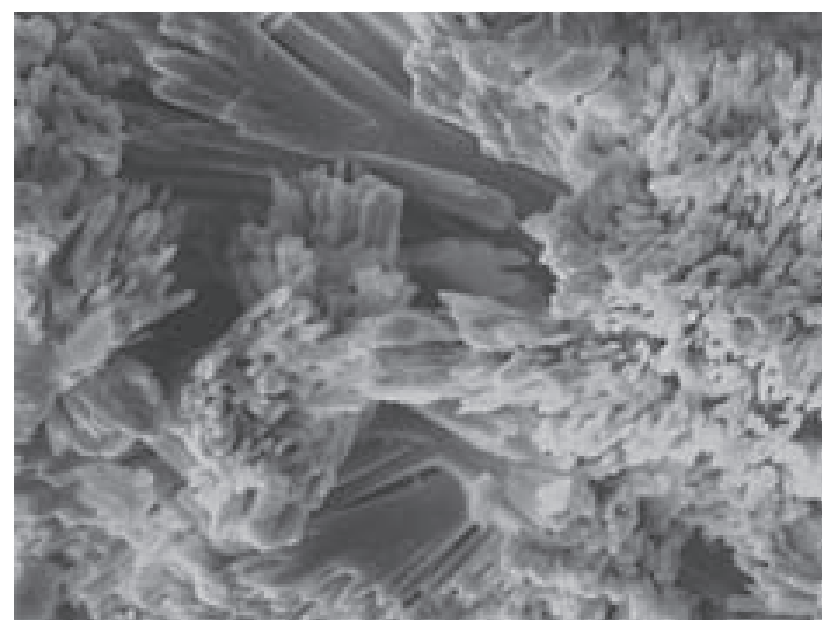

Fig. 11 Aggregate of elongated tabular cannonite crystals. Huber open pit, Krásno; width of SE photo $35 \mu \mathrm{m}$; SEM Tesla 320 (A. Gabašová).
Table 9 Unit-cell parameters of cannonite (for monoclinic space group $P 2_{1} / c$ )

\begin{tabular}{|l|ccc|}
\hline & $\begin{array}{c}\text { Huber stock } \\
\text { this paper }\end{array}$ & $\begin{array}{c}\text { Marysvale } \\
\text { Stanley et al. }(1992)\end{array}$ & $\begin{array}{c}\text { synt. } \\
\text { Golic } \text { et al. }(1982)\end{array}$ \\
\hline $\mathrm{a}[\AA]$ & $7.703(1)$ & $7.700(3)$ & $7.692(3)$ \\
$\mathrm{b}[\AA]$ & $13.883(2)$ & $13.839(6)$ & $13.87(1)$ \\
$\mathrm{c}[\AA]$ & $5.695(1)$ & $5.686(2)$ & $5.688(2)$ \\
$ß\left[{ }^{\circ}\right]$ & $109.04(2)$ & $109.11(3)$ & $109.01(3)$ \\
$\mathrm{V}\left[\AA^{3}\right]$ & 575.7 & $572.5(4)$ & 573.75 \\
\hline
\end{tabular}

\section{Chalcanthite $\mathrm{CuSO}_{4} \cdot 5 \mathrm{H}_{2} \mathrm{O}$}

It was previously described by Slavíček (1984) from surface outcrops at the Huber stock. At present, it is confirmed as a common mineral in the Huber open pit. Blue chalcanthite coatings and stalactitic crusts are 
composed of minute crystals, which formed sub-recently at dry sites in the exposed greisen (Fig. 12). It is often associated with clay minerals, chiefly dickite. As acidity at the particular site is decreasing, chalcanthite alters to other supergene copper minerals, usually brochantite. Chalcanthite was identified by X-ray powder diffraction.

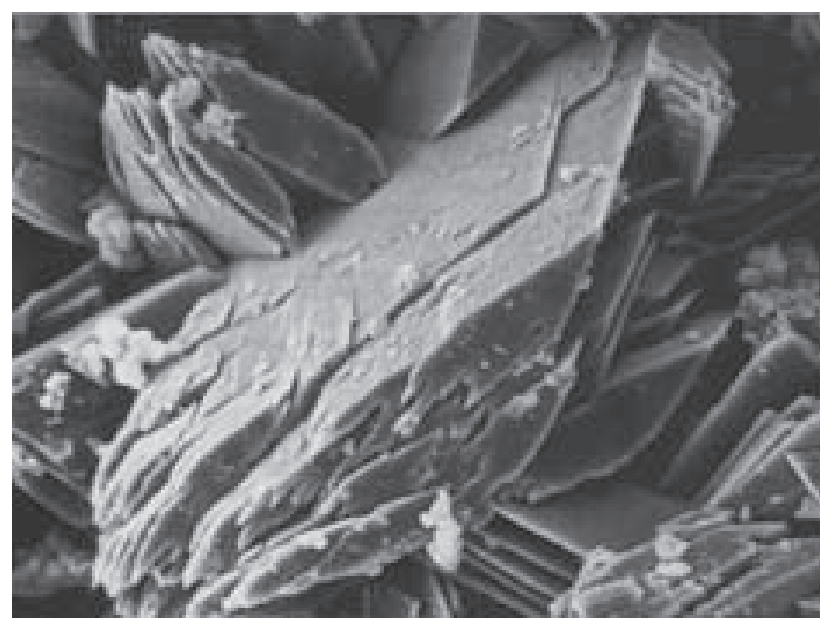

Fig. 12 Crystal of sub-recently formed chalcanthite. Huber open pit; width of SE photo $100 \mu \mathrm{m}$; SEM Jeol JSM T-20 (Z. Mach).

\section{Chalcophyllite $\mathrm{Cu}_{18} \mathrm{Al}_{2}\left(\mathrm{AsO}_{4}\right)_{4}\left(\mathrm{SO}_{4}\right)_{3}(\mathrm{OH})_{24} \cdot 36 \mathrm{H}_{2} \mathrm{O}$}

Chalcophyllite forms tabular crystals of trigonal or pseudo-hexagonal shape (Figs 13, 14), $1 \mathrm{~mm}$ or exceptionally up to $3 \mathrm{~mm}$ in size. The crystals occur individually (Fig. 15) or in rich crystalline coatings (Fig. 16) on quartz or highly weathered relics of sulfides in cavities in greisen. Chalcophyllite crystals are light turquoise blue to dark green, transparent to translucent with a characteristic and very intense vitreous lustre. All studied samples were collected at the Huber open pit. Pharmacosiderite and other supergene minerals occur in the association.

The X-ray powder diffraction pattern and the refined unit-cell parameters (Table 10) for sample from the $\mathrm{Hu}-$ ber open pit fit well with the data given by Sabelli (1980).

The quantitative chemical analysis of chalcophyllite (Table 11) gives the following empirical formula based on $88(\mathrm{O}, \mathrm{OH}): \mathrm{Cu}_{17.85} \mathrm{Al}_{2.09}\left[\left(\mathrm{AsO}_{4}\right)_{3.38}\left(\mathrm{PO}_{4}\right)_{0.23}\right]_{\Sigma 3.61}$ $\left(\mathrm{SO}_{4}\right)_{3.20}(\mathrm{OH})_{24.75} \cdot 36 \mathrm{H}_{2} \mathrm{O}$. Sabelli (1980) determined the structure of an As-rich chalcophyllite from Cornwall and pointed out that up to $25 \%$ of $\mathrm{S}$ in some positions can be substituted by As. This author proposed the crystal-

Table 10 Unit-cell parameters of chalcophyllite (for trigonal space group $R-3 H$ )

\begin{tabular}{|l|cc|}
\hline & $\begin{array}{c}\text { Huber stock } \\
\text { this paper }\end{array}$ & $\begin{array}{c}\text { Cornwall } \\
\text { Sabelli }(1980)\end{array}$ \\
\hline a $[\AA]$ & $10.757(2)$ & $10.756(2)$ \\
c $[\AA]$ & $28.677(6)$ & $28.678(4)$ \\
$\mathrm{V}\left[\AA^{3}\right]$ & 2873.7 & 2873.3 \\
\hline
\end{tabular}

lochemical formula $\mathrm{Cu}_{18} \mathrm{Al}_{2}\left(\mathrm{AsO}_{4}\right)_{4}\left(\mathrm{SO}_{4}\right)_{3}(\mathrm{OH})_{24} \cdot 36 \mathrm{H}_{2} \mathrm{O}$, which is in a good agreement with the data for chalcophyllite from Horní Slavkov.

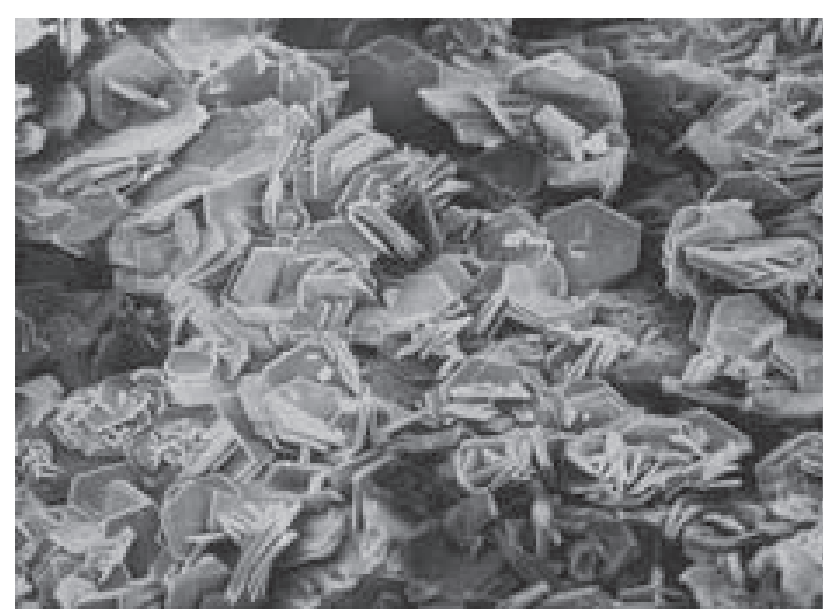

Fig. 13 Typical thin tabular, pseudo-hexagonal crystals of chalcophyllite. Huber open pit, Krásno; width of SE photo $650 \mu \mathrm{m}$; SEM Tesla 320 (A. Gabašová).

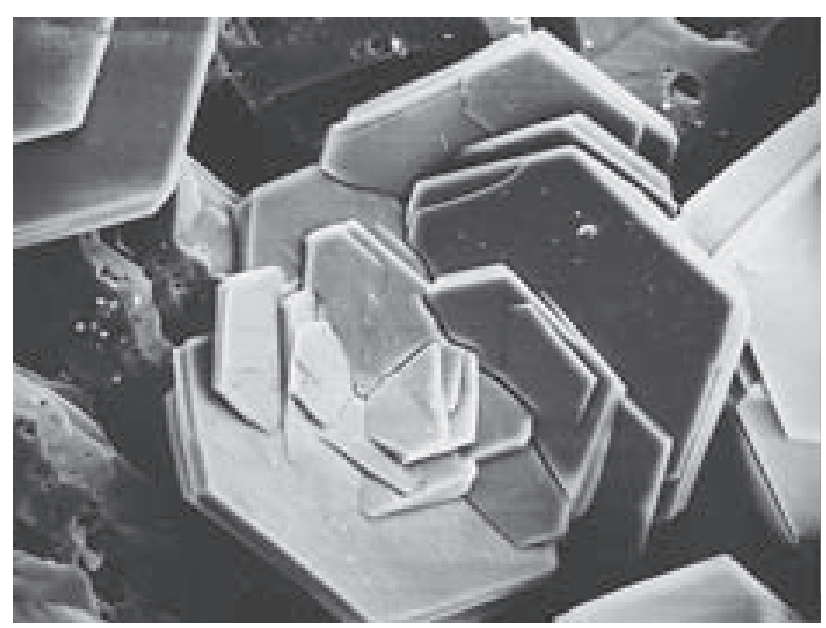

Fig. 14 Detail of pseudo-hexagonal crystals of chalcophyllite. Huber open pit, Krásno, width of SE photo $100 \mu \mathrm{m}$; SEM Jeol JSM T-20 (Z. Mach).

Table 11 Chemical composition of chalcophyllite (in wt. \%)

\begin{tabular}{|l|rr|}
\hline & $* 1$ & $* 2$ \\
\hline $\mathrm{CuO}$ & 46.43 & 46.21 \\
$\mathrm{Al}_{2} \mathrm{O}_{3}$ & 3.49 & 3.29 \\
$\mathrm{As}_{2} \mathrm{O}_{5}$ & 12.70 & 14.84 \\
$\mathrm{P}_{2} \mathrm{O}_{5}$ & 0.53 & \\
$\mathrm{SO}_{3}$ & 8.39 & 7.75 \\
$\mathrm{H}_{2} \mathrm{O}^{*}$ & 28.49 & 27.91 \\
total & 100.03 & 100.00 \\
\hline
\end{tabular}

* $\mathrm{H}_{2} \mathrm{O}$ calculated from soichiometry of the ideal formula $\mathrm{Cu}_{18} \mathrm{Al}_{2}\left(\mathrm{AsO}_{4}\right)_{4}\left(\mathrm{SO}_{4}\right)_{3}(\mathrm{OH})_{24} \cdot 36 \mathrm{H}_{2} \mathrm{O}$ and charge balance.

*1 Huber stock, Krásno

*2 composition calculated from the ideal formula $\mathrm{Cu}_{18} \mathrm{Al}_{2}\left(\mathrm{AsO}_{4}\right)_{4}\left(\mathrm{SO}_{4}\right)_{3}(\mathrm{OH})_{24} \cdot 36 \mathrm{H}_{2} \mathrm{O}$. 
Fig. 15 Individual chalcophyllite crystals deposited on crystals of translucent or white quartz. Huber open pit, Krásno; width of photo $3.2 \mathrm{~mm}$. Nicon SMZ1500 microphotography (J. \& E. Sejkora).

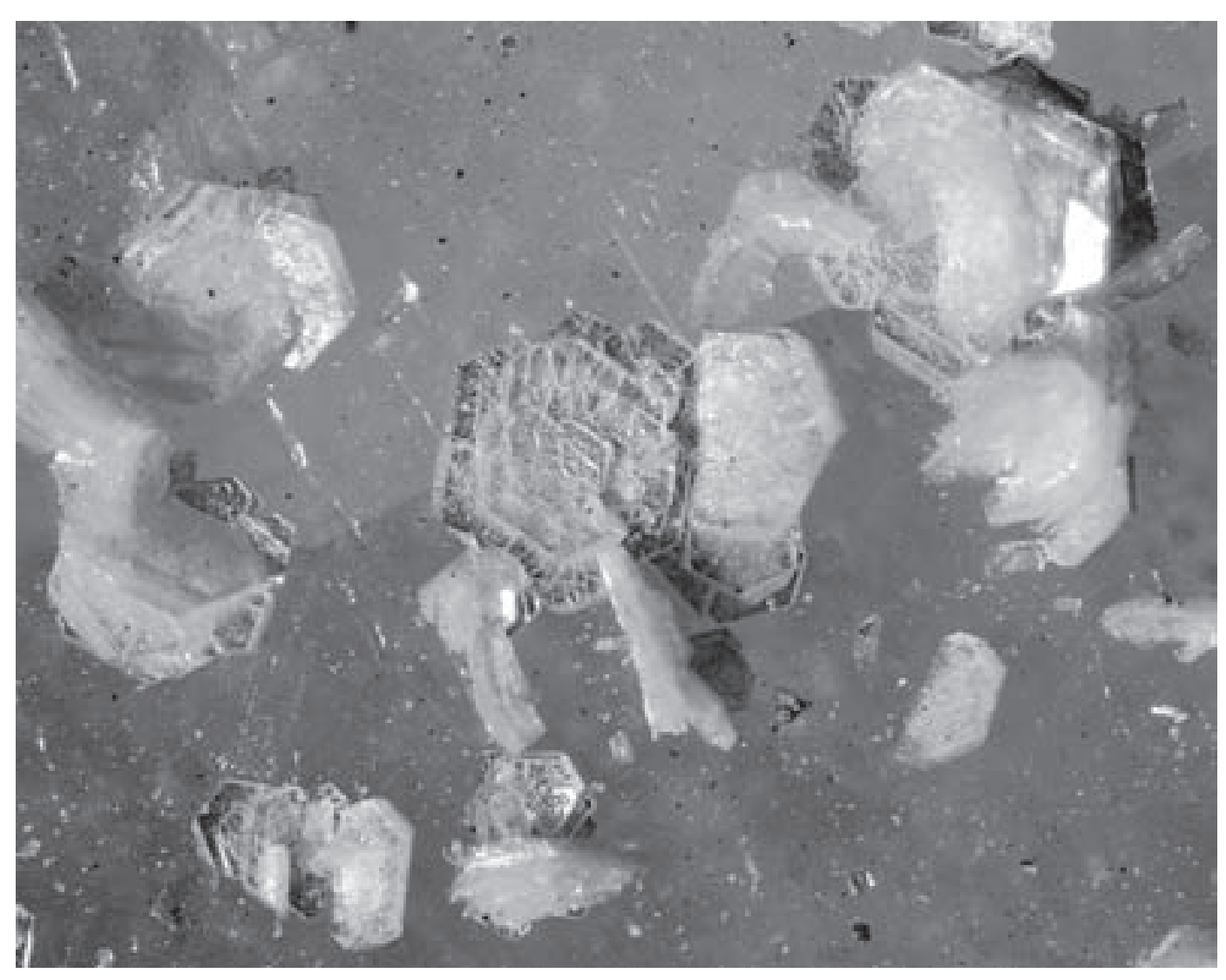

Fig. 16 Crystalline crust of randomly oriented chalcophyllite crystals. Huber open pit, Krásno; width of photo $6 \mathrm{~mm}$. Nicon SMZ1500 microphotography (J. \& E. Sejkora).

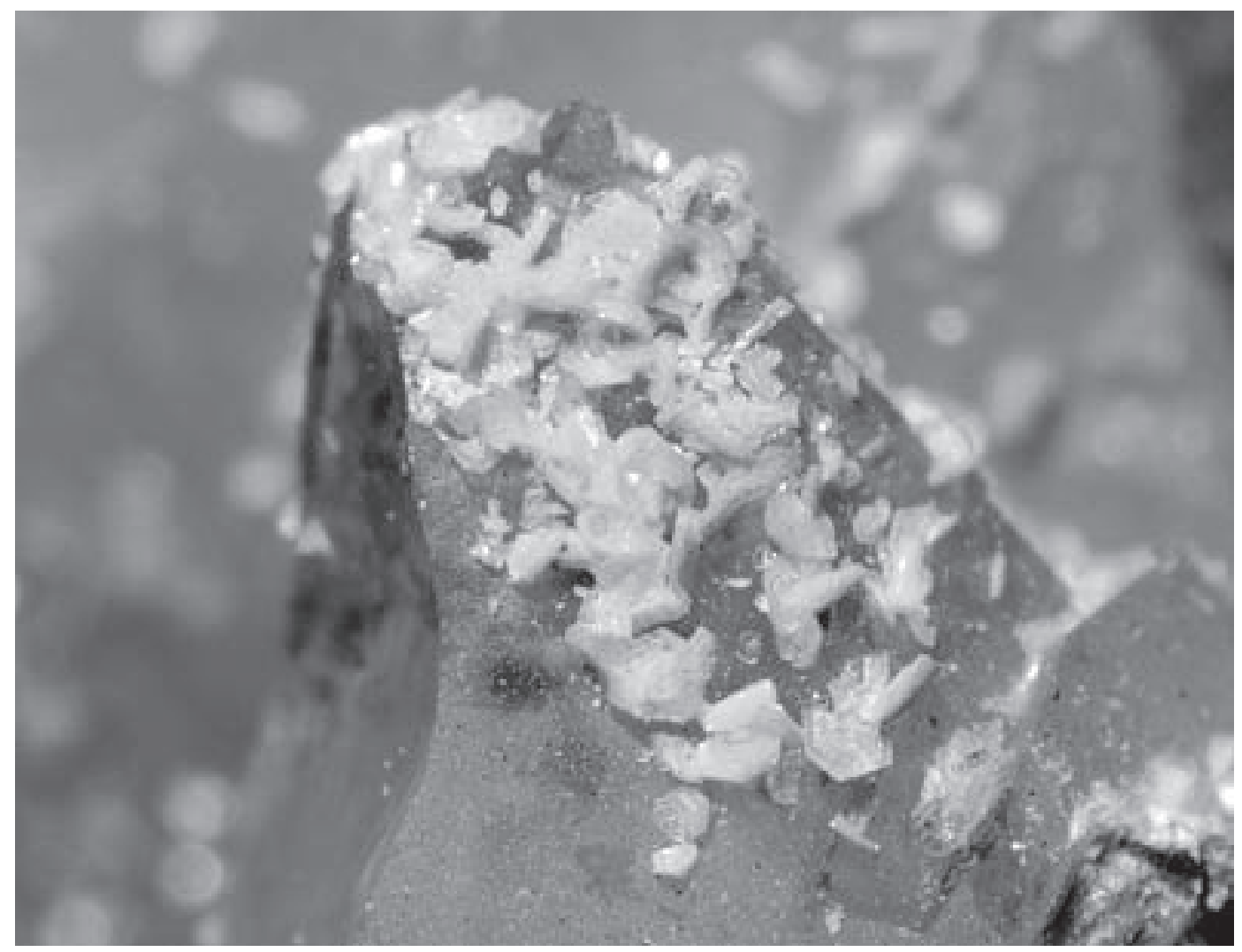




\section{Chalcosiderite $\mathrm{CuFe}_{6}^{3+}{ }_{6} \mathrm{PO}_{4}(\mathrm{OH})_{2} \mathrm{l}_{4} \cdot 4 \mathrm{H}_{2} \mathrm{O}$}

Tacl - Blüml (1974) and Mach (1979) described crystalline chalcosiderite from the Huber open pit. The mineral occurs in quartz gangue and is associated with wolframite and Fe-oxy-hydroxides as fibrous and spheroidal aggregates of emerald green colour. Korbel (1991) reported spectral analysis and X-ray powder data for green, roseshaped aggregates, up to $1.5 \mathrm{~mm}$ in size, of chalcosiderite, consisting of thin slabs, which overgrow wolframite. Beran (1999) described chalcosiderite crystals and aggregates, up to $1 \mathrm{~mm}$ long, from the Huber open pit. They are associated with pharmacosiderite and other supergene minerals in cavities of vein quartz.

In the course of the present study minerals of the turquoise group have been found at the $5^{\text {th }}$ level of the Huber shaft and in the Huber open pit. As these samples were typically associated with altered phosphate accumulation, they are described in detail in another article included in this issue (Sejkora et al. 2006b).

\section{Chenevixite $\mathrm{Cu}_{2} \mathrm{Fe}^{3+}{ }_{2}\left(\mathrm{AsO}_{4}\right)_{2}(\mathrm{OH})_{4} \cdot \mathrm{H}_{2} \mathrm{O}$}

It has been found in several samples of quartz gangue collected near fracture zones in the Huber open pit. Chenevixite occurs in several morphological forms: yellow green to olive green powdery coatings and filling of small vugs, green brown compact aggregates, and dark green compact, and relatively hard aggregates with con- choidal fracture (Fig. 17) and botryoidal surface (Fig. 18a) featuring very tiny (to $2-3 \mu \mathrm{m}$ ) imperfect elongated tabular crystals (Fig. 18b). It occurs in the vicinity of weathered arsenopyrite and chalcopyrite, associated with scorodite, pharmacosiderite and limonite. Some chenevixite aggregates carry fractured angular cassiterite, locally are overgrown by varlamoffite (Fig. 19).

Chenevixite was identified by X-ray powder diffraction (Table 12) and the data are in good agreement with the published data. Unlike the compact varieties, powdery chenevixite shows lower intensities of diffraction maxima and higher values of their FWHM half-widths. The refined unit-cell parameters of chenevixite from Krásno (Table 13) correspond to the published values. All the three morphological types of chenevixite are compositionally nearly identical. No chemical zoning has been observed in BSE images. The high totals of chemical analyses (Table 14) are probably caused by a partial dehydration of the mineral under electron beam in vacuum. The studied chenevixite is notably a $\mathrm{Cu}-, \mathrm{Fe}-$, and Asdominated member. Minor components include $\mathrm{Zn}$ to $0.05 a p f u$, Al to $0.09 a p f u$ and P to $0.12 a p f u$. The obvious deficiency in the anionic group (ca. 1.74 apfu instead of $2.00 \mathrm{apfu}$ ) is probably compensated for by entry of additional $(\mathrm{OH})$ group, as indicated by the empirical formula given below. The role of $(\mathrm{OH}) / \mathrm{H}_{2} \mathrm{O}$ in minerals of the chenevixite-luetheite series is not completely known. In difference to previous publications, Burns et al. (2000) in their study of the crystal structure do not mention the

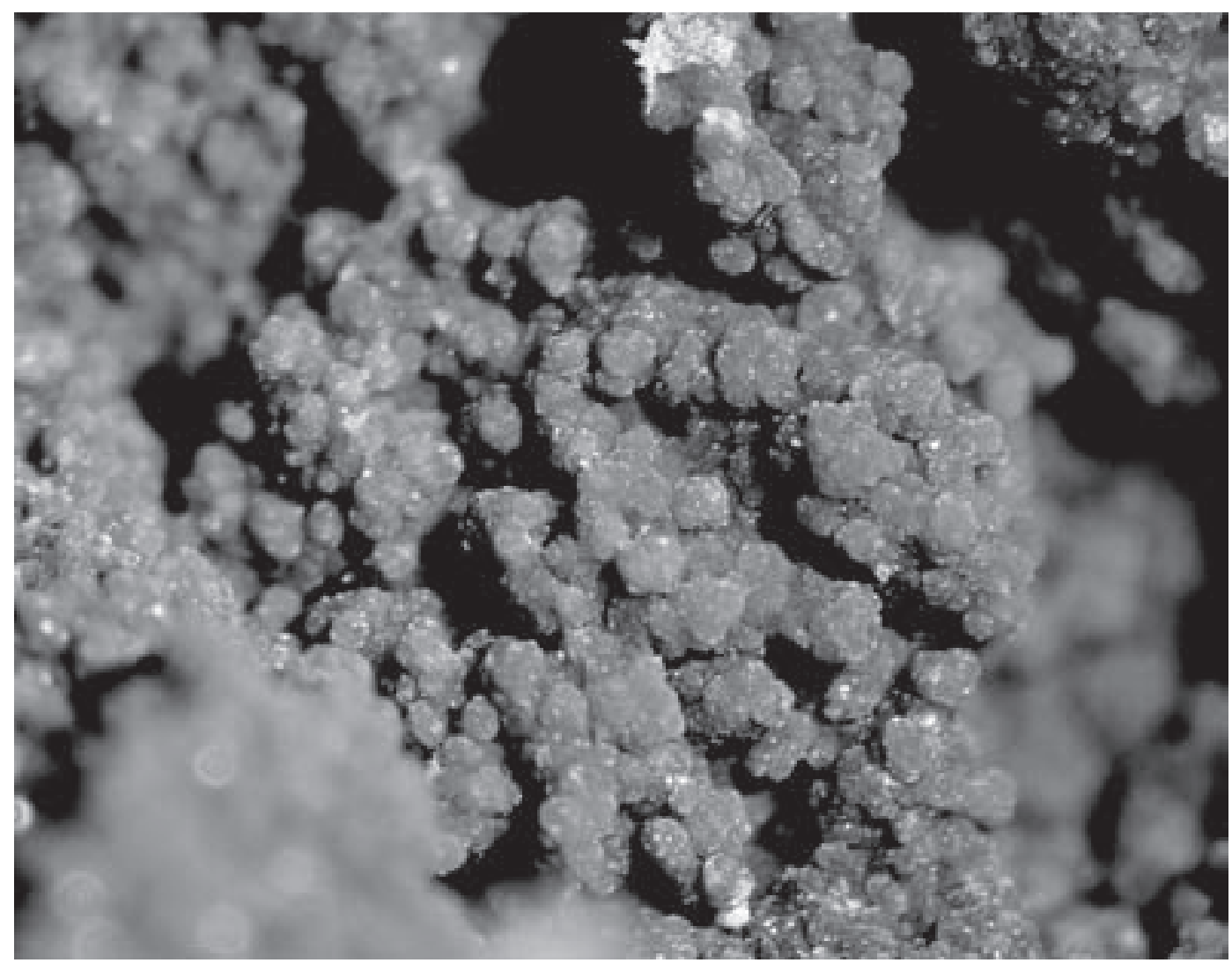

Fig. 17 Chenevixite aggregate with finely crystalline surface. Huber open pit, Krásno; width of photo $2 \mathrm{~mm}$. Nicon SMZ1500 microphotography (J. \& E. Sejkora). 


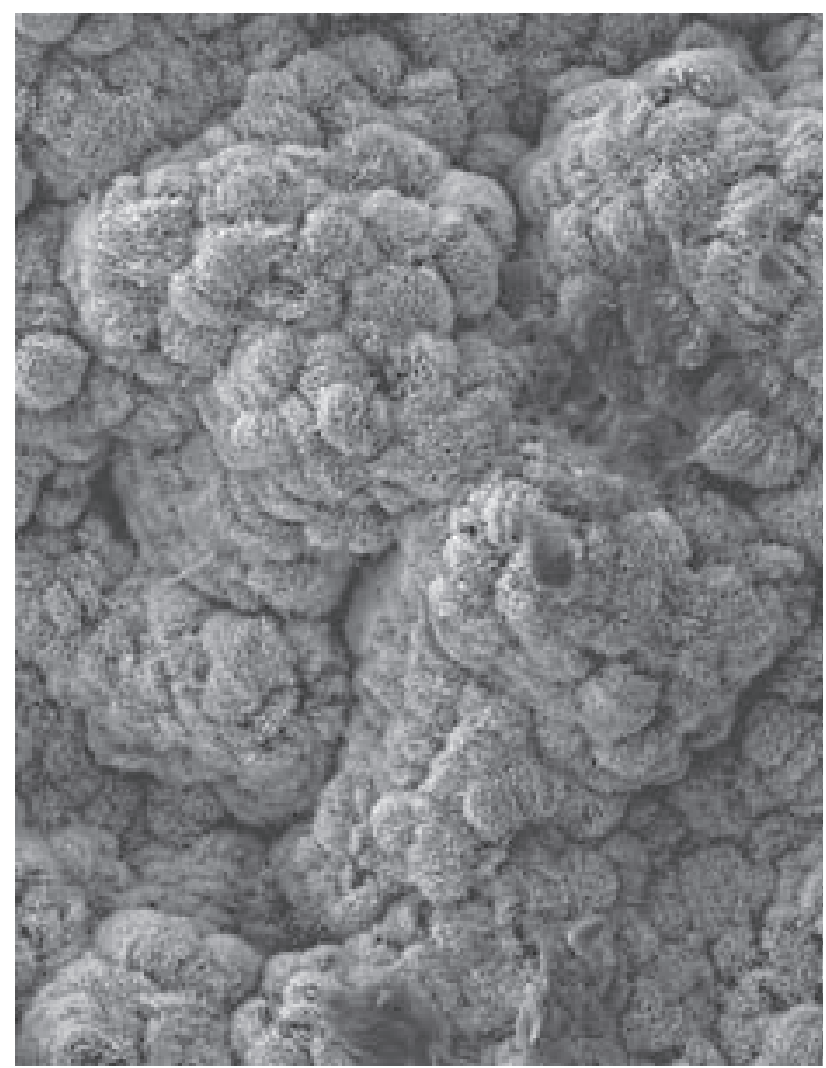

Fig. 18a Minute chenevixite crystals on the surface of the aggregate. Huber open pit; width of SE photo $150 \mu \mathrm{m}$. SEM Jeol JSM-6380 (J. Sejkora and J. Plášil).

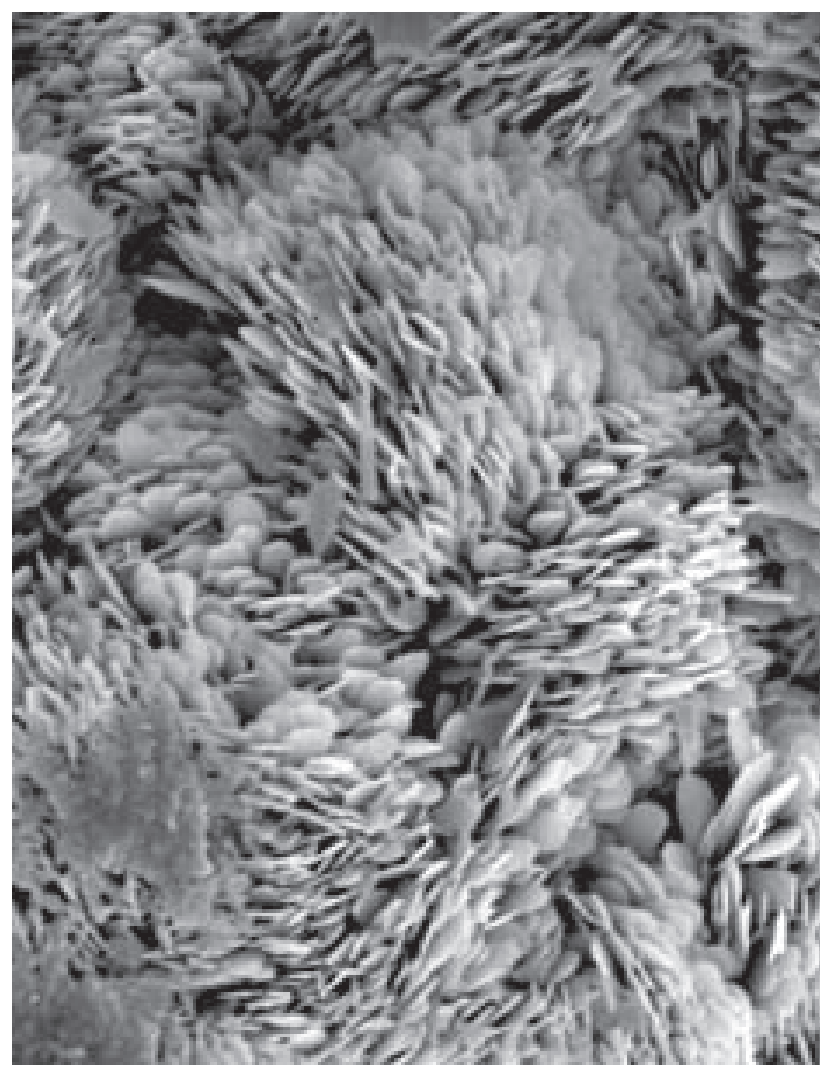

Fig. 18b Detail of the surface of chenevixite crystal aggregate showing imperfect, elongated tabular crystals. Huber open pit; width of SE photo $20 \mu \mathrm{m}$. SEM Jeol JSM-6380 (J. Sejkora and J. Plášil).

Table 12 X-ray powder diffraction data of chenevixite from Krásno

\begin{tabular}{|c|c|c|c|c|c|c|c|c|c|c|c|c|c|c|}
\hline$I_{r e l}$ & $d$ & $h$ & $k$ & $l$ & $I_{r e l}$ & $d$ & $h$ & $k$ & $l$ & $I_{r e l}$ & $d$ & $h$ & $k$ & $l$ \\
\hline 6 & 7.362 & 0 & 0 & 4 & 11 & 2.0576 & 1 & 2 & -7 & 31 & 1.4789 & 2 & 1 & -16 \\
\hline 10 & 4.875 & 0 & 1 & 2 & 3 & 1.9413 & 1 & 1 & -13 & 29 & 1.4766 & 2 & 3 & 0 \\
\hline 22 & 4.227 & 0 & 1 & 4 & 17 & 1.9057 & 1 & 2 & 9 & 33 & 1.4679 & 2 & 3 & -2 \\
\hline 41 & 3.805 & 1 & 1 & 1 & 31 & 1.9003 & 2 & 2 & 2 & 33 & 1.4679 & 2 & 3 & 2 \\
\hline 32 & 3.561 & 1 & 1 & 3 & 31 & 1.9003 & 2 & 2 & -2 & 38 & 1.4298 & 4 & 0 & 0 \\
\hline 100 & 3.553 & 0 & 1 & 6 & 27 & 1.8542 & 2 & 2 & 4 & 11 & 1.4139 & 2 & 3 & -6 \\
\hline 37 & 2.9927 & 0 & 1 & 8 & 2 & 1.8542 & 2 & 2 & -4 & 11 & 1.4139 & 2 & 3 & 6 \\
\hline 11 & 2.5794 & 0 & 2 & 0 & 9 & 1.8352 & 0 & 0 & 16 & 23 & 1.3784 & 0 & 2 & 18 \\
\hline 57 & 2.5521 & 0 & 1 & 10 & 13 & 1.7841 & 2 & 2 & 6 & 28 & 1.3263 & 4 & 1 & 6 \\
\hline 62 & 2.5016 & 2 & 1 & 0 & 13 & 1.7841 & 2 & 2 & -6 & 28 & 1.3263 & 4 & 1 & -6 \\
\hline 89 & 2.4692 & 2 & 0 & 6 & 21 & 1.7630 & 1 & 2 & -11 & 26 & 1.2928 & 0 & 4 & 0 \\
\hline 89 & 2.4692 & 2 & 0 & -6 & 20 & 1.7570 & 3 & 1 & -3 & 11 & 1.2501 & 4 & 2 & 0 \\
\hline 19 & 2.4350 & 0 & 2 & 4 & 23 & 1.7486 & 2 & 1 & 12 & 13 & 1.2487 & 3 & 3 & 5 \\
\hline 8 & 2.3680 & 2 & 1 & 4 & 23 & 1.7486 & 2 & 1 & -12 & 21 & 1.2472 & 4 & 1 & 10 \\
\hline 36 & 2.2839 & 1 & 2 & -3 & 29 & 1.6753 & 0 & 3 & 4 & 7 & 1.2323 & 4 & 2 & -4 \\
\hline 36 & 2.2839 & 0 & 2 & 6 & 53 & 1.6063 & 2 & 2 & 10 & 7 & 1.2323 & 4 & 2 & 4 \\
\hline 34 & 2.2276 & 2 & 1 & 6 & 53 & 1.6063 & 2 & 2 & -10 & 19 & 1.1456 & 2 & 4 & 6 \\
\hline 34 & 2.2276 & 2 & 1 & -6 & 53 & 1.6063 & 2 & 1 & 14 & 19 & 1.1456 & 2 & 4 & - \\
\hline 23 & 2.0688 & 2 & 1 & 8 & 53 & 1.6063 & 2 & 1 & -14 & 8 & 1.1422 & 0 & 4 & 12 \\
\hline 23 & 2.0688 & 2 & 1 & -8 & 40 & 1.4965 & 0 & 2 & 16 & & & & & \\
\hline 11 & 2.0576 & 1 & 2 & 7 & 48 & 1.4789 & 2 & 1 & 16 & & & & & \\
\hline
\end{tabular}




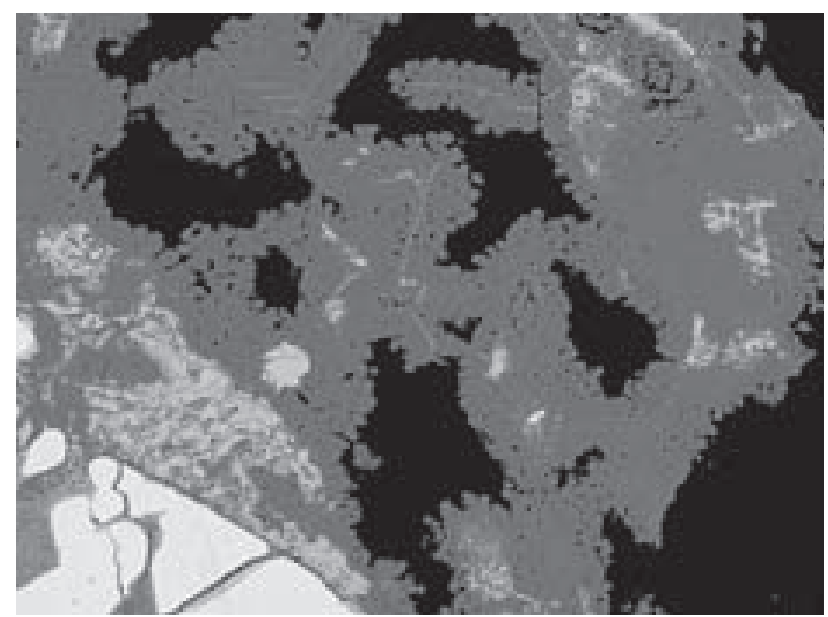

Fig. 19 Chenevixite aggregates, partly with crystal faces (dark grey), enlose irregular "varlamoffite" and fractured cassiterite grains (light grey). Width of BSE photo $300 \mu \mathrm{m}$. Cameca SX100 (J. Sejkora, R. Škoda).

Ta ble 13 Unit-cell parameters of chenevixite (for monoclinic space group $B 2_{1}$ )

\begin{tabular}{|l|cc|}
\hline & $\begin{array}{c}\text { Krásno } \\
\text { this paper }\end{array}$ & $\begin{array}{c}\text { Humboldt mine, Arizona } \\
\text { Burns } \text { et al. }(2000)\end{array}$ \\
\hline $\mathrm{a}[\AA] \mathrm{A}]$ & $5.717(1)$ & $5.7012(8)$ \\
$\mathrm{b}[\AA]$ & $5.169(1)$ & $8.1801(7)$ \\
$\mathrm{c}[\AA]$ & $29.344(9)$ & $29.265(2)$ \\
$ß\left[{ }^{\circ}\right]$ & $89.99(2)$ & $89.99(1)$ \\
$\mathrm{V}\left[\AA^{3}\right]$ & $867.2(2)$ & $864.3(4)$ \\
\hline
\end{tabular}

Table 14 Chemical composition of chenevixite (in wt. \%)

\begin{tabular}{|l|rcr|}
\hline & mean*1 & range*1 & $* 2$ \\
\hline $\mathrm{CaO}$ & 0.05 & $0.00-0.08$ & \\
$\mathrm{CuO}$ & 29.14 & $27.80-30.64$ & 26.40 \\
$\mathrm{ZnO}$ & 0.60 & $0.46-0.75$ & \\
$\mathrm{Al}_{2} \mathrm{O}_{3}$ & 0.73 & $0.63-0.86$ & \\
$\mathrm{Fe}_{2} \mathrm{O}_{3}$ & 29.47 & $28.86-30.75$ & 26.50 \\
$\mathrm{SiO}_{2}$ & 0.08 & $0.00-0.30$ & \\
$\mathrm{As}_{2} \mathrm{O}_{5}$ & 35.17 & $33.91-35.77$ & 38.13 \\
$\mathrm{P}_{2} \mathrm{O}_{5}$ & 1.17 & $1.06-1.48$ & \\
$\mathrm{SO}_{3}$ & 0.03 & $0.00-0.07$ & \\
$\mathrm{H}_{2} \mathrm{O}^{*}$ & 10.88 & & 8.97 \\
total & 107.32 & & 100.00 \\
\hline
\end{tabular}

$* \mathrm{H}_{2} \mathrm{O}$ content calculated from the ideal formula

$\mathrm{Cu}_{2} \mathrm{Fe}_{2}^{3+}\left(\mathrm{AsO}_{4}\right)_{2}(\mathrm{OH})_{4} \cdot \mathrm{H}_{2} \mathrm{O}$ and charge balance.

* 1 mean and range of 8 spot analyses in 3 samples

$* 2$ composition calculated from ideal formula $\mathrm{Cu}_{2} \mathrm{Fe}^{3+}{ }_{2}\left(\mathrm{AsO}_{4}\right)_{2}(\mathrm{OH})_{4} \cdot \mathrm{H}_{2} \mathrm{O}$

formerly proposed content of one $\mathrm{H}_{2} \mathrm{O}$ molecule. Based on $13(\mathrm{O}, \mathrm{OH})$ the chenevixite from Krásno yielded the following empirical formula:

$$
\left(\mathrm{Cu}_{1.98} \mathrm{Zn}_{0.04}\right)_{\Sigma 2.02}\left(\mathrm{Fe}_{1.99} \mathrm{Al}_{0.08}\right)_{\Sigma 2.07}\left[\left(\mathrm{AsO}_{4}\right)_{1.65}\left(\mathrm{PO}_{4}\right)_{0.09}\right]_{\Sigma 1.74}
$$
$(\mathrm{OH})_{5.00} \cdot 1.00 \mathrm{H}_{2} \mathrm{O}$.

\section{Chrysocolla $(\mathrm{Cu}, \mathrm{Al})_{2} \mathrm{H}_{2} \mathrm{Si}_{2} \mathrm{O}_{5}(\mathrm{OH})_{4} \cdot \mathrm{nH}_{2} \mathrm{O}$}

Klvaňa (1886) previously described compact and earthy chrysocolla associated with quartz, limonite and mala- chite. Recently, light blue to green blue chrysocolla as mammilary and stalactitic accumulations has been found in greisen at the VII ${ }^{\text {th }}$ level of the Schnöd stock. It is associated with goyazite, malachite, pseudomalachite and apatite. Chrysocolla has also been found in material of historic dumps around the Huber stock as irregular aggregates up to $4 \mathrm{~cm}$ in size, in cavities and fractures of quartz gangue.

\section{Clinoclase $\mathrm{Cu}_{3}\left(\mathrm{AsO}_{4}\right)(\mathrm{OH})_{3}$}

The mineral was found as a rarity in quartz gangue within old dumps between the Huber open pit and the ventilation shaft No. 2. Clinoclase forms minute black green, highly lustrous crystals, up to $1 \mathrm{~mm}$ long, in part showing radiating aggregates. The mineral was identified by X-ray powder diffraction.

\section{Copper $\mathrm{Cu}$}

Native copper was reported already in mid- $19^{\text {th }}$ century at Horní Slavkov as coatings or dendritic aggregates observed in cavities of ore veins (Krejčí 1855).

During the present study, three genetically distinct types of copper have been distinguished. Red brown, finely dendritic copper occurs in part in form of scales or flakes associated with other supergene minerals. The second type forms up to several $\mathrm{cm}$ long grains of red brown colour in strongly altered granite. The third type of copper is of a sub-recent formation in proximity of iron objects in adits of the Huber mine. This copper is finely crystalline or with a moss-like structure; aggregates are up to several $\mathrm{cm}$ long.

\section{Cornwallite $\mathrm{Cu}_{5}\left(\mathrm{AsO}_{4}\right)_{2}(\mathrm{OH})_{4}$}

Rare cornwallite has been found only in several specimens and several distinct types at the Huber open pit. It typically forms green to dark green botryoidal crusts (Fig. 20), up to several mm thick, with hemispherical to spheroidal shapes on the surface (Fig. 21) and radiating structure on cross fracture (Fig. 22). Grey green acicular olivenite is associated with this type of cornwallite. Cornwallite also occurs as crystalline aggregates of imperfect crystals, to $1 \mathrm{~mm}$ long, filling small cavities in quartz. The third type of cornwallite forms green or light green compact crystalline intergrown aggregate with mixite in quartz gangue from a marginal part of the Huber open pit.

Cornwallite was identified by X-ray powder diffraction. The refined unit-cell parameters (Table 15) (especially the $a$ parameter, Arlt - Armbruster 1999) indicate an elevated $\mathrm{P}$ content in the studied samples of cornwallite. The anomalously low value of the $c$ parameter for cornwallite intergrown with mixite remains unexplained. It is necessary to check possible content of $\mathrm{Zn}$ or $\mathrm{Bi}$ in this cornwallite type. 
Fig. 20 Cornwallite aggregates with botryoidal surface. Huber open pit, Krásno; width of photo $3 \mathrm{~mm}$. Nicon SMZ1500 microphotography (J. \& E. Sejkora).

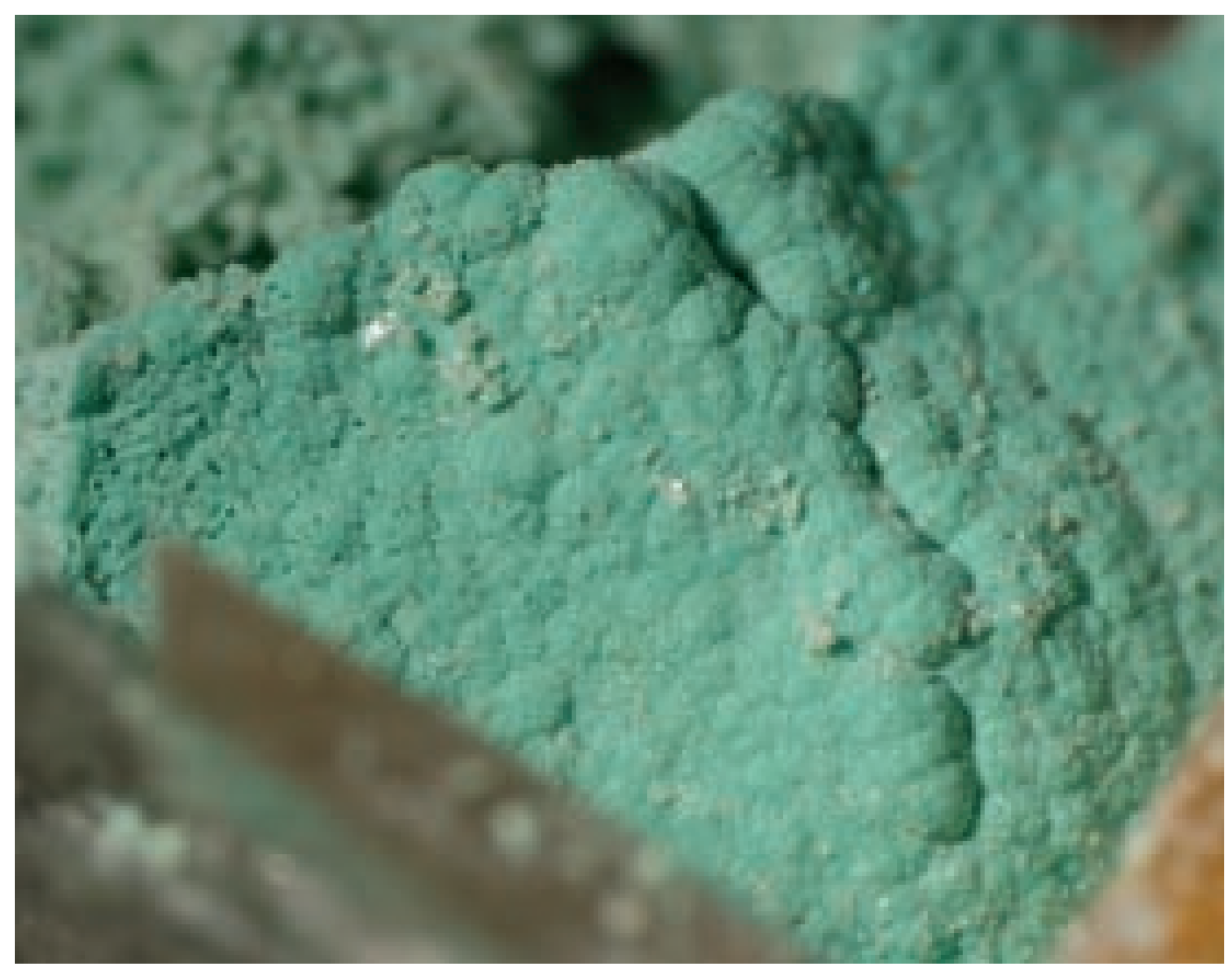

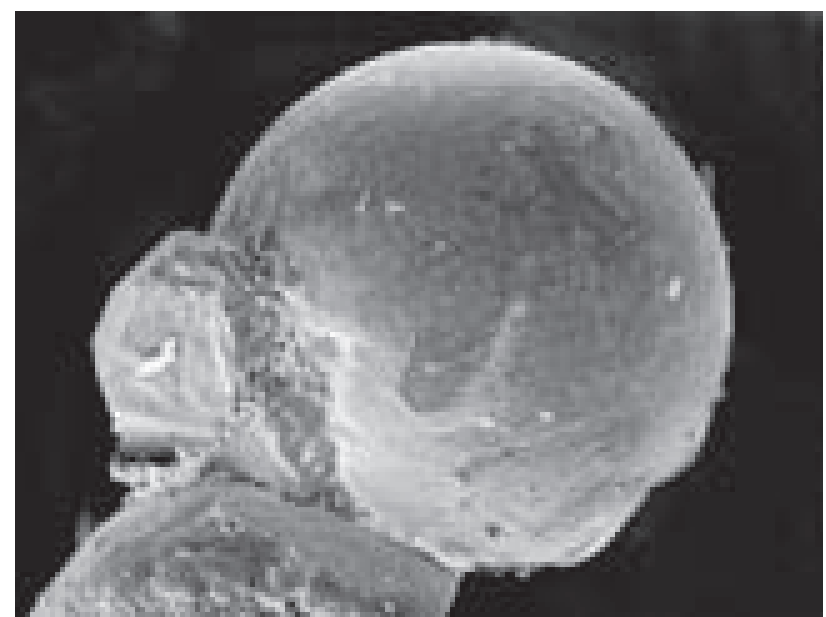

Fig. 21 Semi-spherical to spheroidal cornwallite aggregates. Huber open pit. Width of SE photo $500 \mu \mathrm{m}$; SEM Tesla 320 (A. Gabašová).

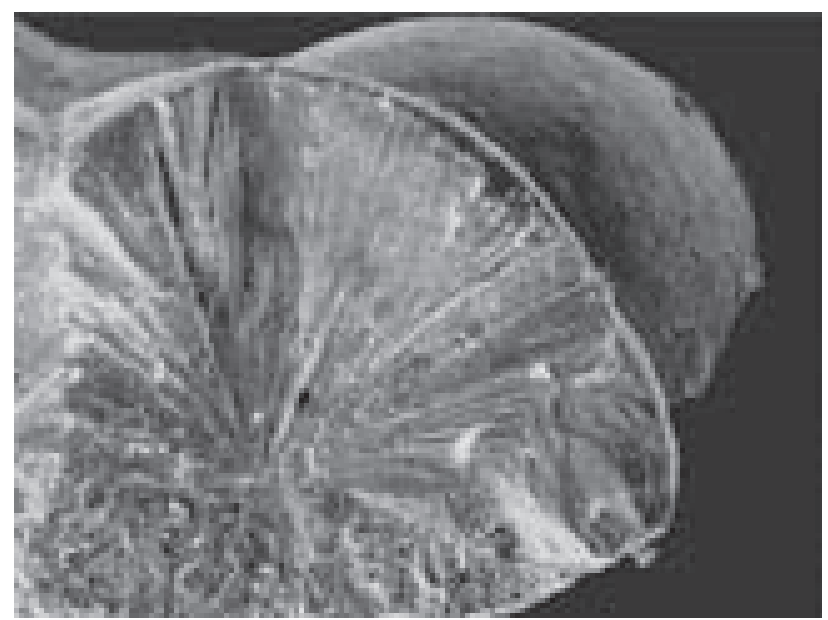

Fig. 22 Radiating internal structure of semi-spherical cornwallite aggregates; Huber open pit; width of SE photo $500 \mu \mathrm{m}$; SEM Tesla 320 (A. Gabašová)

Table 15 Unit-cell parameters of cornwallite (for monoclinic space group $P 2_{1} / c$ )

\begin{tabular}{|l|cccc|}
\hline & $\begin{array}{c}\text { cornwallite } \\
\text { Huber stock } * 1 \\
\text { this paper }\end{array}$ & $\begin{array}{c}\text { cornwallite } \\
\text { Huber stock } * 2 \\
\text { this paper }\end{array}$ & $\begin{array}{c}\text { cornwallite } \\
\text { Clara mine }\end{array}$ & $\begin{array}{c}\text { pseudomalachite } \\
\text { Arlt }- \text { Armbruster (1999) }\end{array}$ \\
\hline a $[\AA]$ & $4.5685(4)$ & $4.545(1)$ & $4.600(2)$ & Shoemaker et al. $(1977)$ \\
b $[\AA]$ & $5.7708(4)$ & $5.796(2)$ & $5.757(3)$ & $5.7728(4)$ \\
c $[\AA]$ & $17.287(1)$ & $16.909(4)$ & $17.380(6)$ & $17.302(3)$ \\
$ß\left[{ }^{\circ}\right]$ & $93.02(2)$ & $93.02(2)$ & $91.87(3)$ & $91.043(7)$ \\
$\mathrm{V}\left[\AA^{3}\right]$ & 455.1 & 444.8 & 460.04 & 437.73 \\
\hline
\end{tabular}

*1 botryoidal crusts of cornwallite

$* 2$ cornwallite in mixture with mixite 


\section{Covellite CuS}

Covellite occurs relatively frequently as dark blue, lustrous and finely crystalline coatings in cavities in quartz, with relics of primary minerals, especially chalcopyrite. It has also been observed as coating in corrosion vugs in black scorodite of the oldest generation, deposited on partly weathered cassiterite. Covellite formed during cementation process on the surface of primary chalcopyrite and arsenopyrite. It occurs in association with supergene silver, two generations of scorodite, supergene cassiterite and pharmacosiderite. Covellite was identified by X-ray powder diffraction, and the refined unit-cell parameters correspond well to the published data (Table 16).

Table 16 Unit-cell parameters of covellite (for hexagonal space group $\mathrm{Pb}_{3} / \mathrm{mmc}$ )

\begin{tabular}{|l|cc|}
\hline & $\begin{array}{c}\text { Krásno } \\
\text { this paper }\end{array}$ & $\begin{array}{c}\text { synt. } \\
\text { Fjellvag } \text { et al. }(1988)\end{array}$ \\
\hline $\mathrm{a}[\AA]$ & $3.7833(2)$ & $3.7917(8)$ \\
$\mathrm{c}[\AA]$ & $16.3430(7)$ & $16.342(3)$ \\
$\mathrm{V}\left[\AA^{3}\right]$ & 202.60 & 203.47 \\
\hline
\end{tabular}

\section{Cuprite $\mathrm{Cu}_{2} \mathrm{O}$}

Klvaňa (1866) reported cuprite as compact, granular and finely crystalline aggregates. The present study confirmed cuprite in the Huber open pit as finely crystalline aggregates (Fig. 23) of a dark red colour, up to $5 \mathrm{~mm}$ in size.
The mineral was identified by X-ray powder diffraction. The refined unit-cell parameters correspond well to the published data (Table 17).

Table 17 Unit-cell parameters of cuprite (for cubic space group $P n-3 m$ )

\begin{tabular}{|l|cc|}
\hline & $\begin{array}{c}\text { Huber stock } \\
\text { this paper }\end{array}$ & $\begin{array}{c}\text { synt. } \\
\text { Restori }- \text { Schwarzenbach (1986) }\end{array}$ \\
\hline $\mathrm{a}[\AA]$ & $4.2684(2)$ & $4.267(2)$ \\
$\mathrm{V}\left[\AA^{3}\right]$ & 77.77 & 77.69 \\
\hline
\end{tabular}

\section{Cyanotrichite $\mathrm{Cu}_{4} \mathrm{Al}_{2}\left(\mathrm{SO}_{4}\right)(\mathrm{OH})_{12} \cdot 2 \mathrm{H}_{2} \mathrm{O}$}

Cyanotrichite has been identified in several specimens of strongly weathered greisen rich in sulfides, particularly chalcopyrite from the Huber open pit. Cyanotrichite forms discontinuous bright blue coatings 1 by $2 \mathrm{~cm}$ in size (Fig. 24) on quartz and weathered chalcopyrite. The surface of the coatings is formed of tiny spheroidal aggregates $0.1-0.2 \mathrm{~mm}$ in diameter (Fig. 25), consisting of minute platy crystals oriented perpendicular to the surface of the aggregates (Figs 26, 27).

The mineral was identified by X-ray powder diffraction. Quantitative chemical analysis of cyanotrichite is presented in Table 18. The high total of the analysis is probably caused by dehydration of the mineral on exposure to electron beam in vacuum. The analyses obtained show that $\mathrm{Cu}$, $\mathrm{Al}$ and $\mathrm{S}$ are dominant, whereas the contents of $\mathrm{Ca}, \mathrm{Zn}$, $\mathrm{Fe}$, As and $\mathrm{Si}$ are minor, not exceeding 0.03 apfu. The fluorine content is interesting and corresponds approximate-

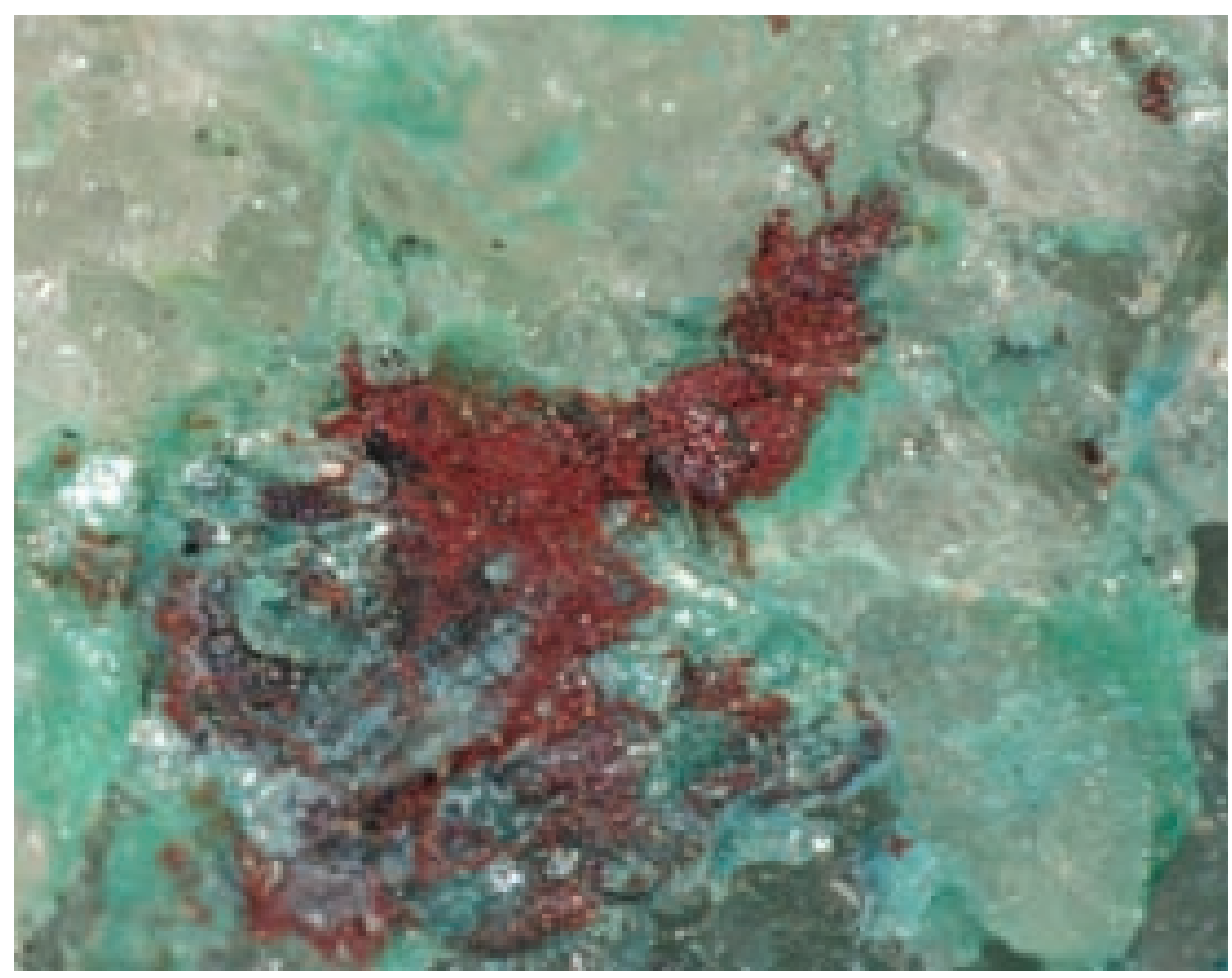

Fig. 23 Red-brown cuprite aggregate on quartz gangue. Huber open pit, Krásno; width of photo $2 \mathrm{~mm}$. Nicon SMZ1500 microphotography (J. \& E. Sejkora). 
Fig. 24 Blue cyanotrichite coatings on weathered quartz gangue carrying chalcopyrite. Huber open pit, Krásno; width of photo $5 \mathrm{~mm}$. Nicon SMZ1500 microphotography (J. \& E. Sejkora).

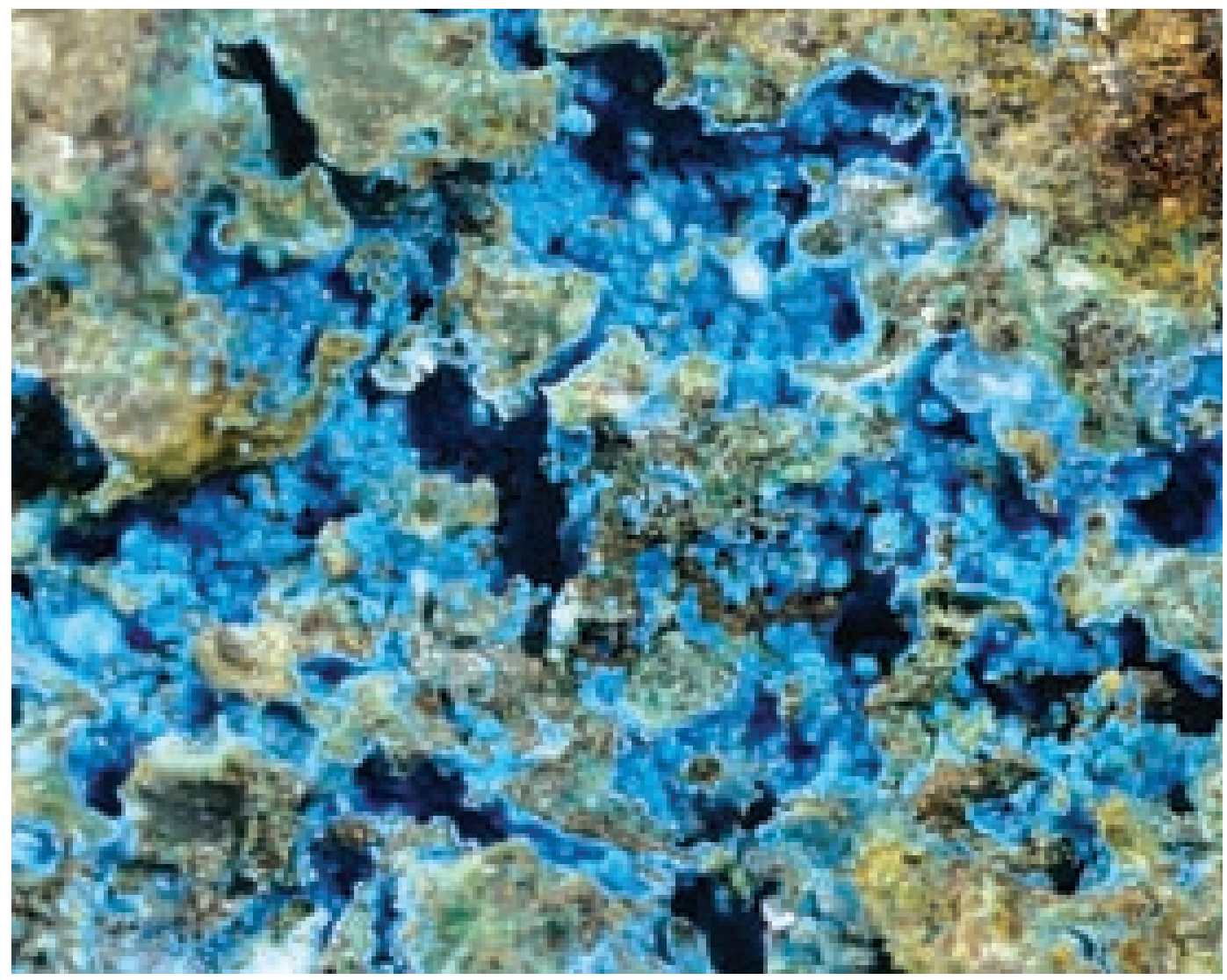

Fig. 25 Spheroidal surface of the blue cyanotrichite aggregate. $\mathrm{Hu}-$ ber open pit, Krásno; width of photo $2 \mathrm{~mm}$. Nicon SMZ1500 microphotography (J. \& E. Sejkora).

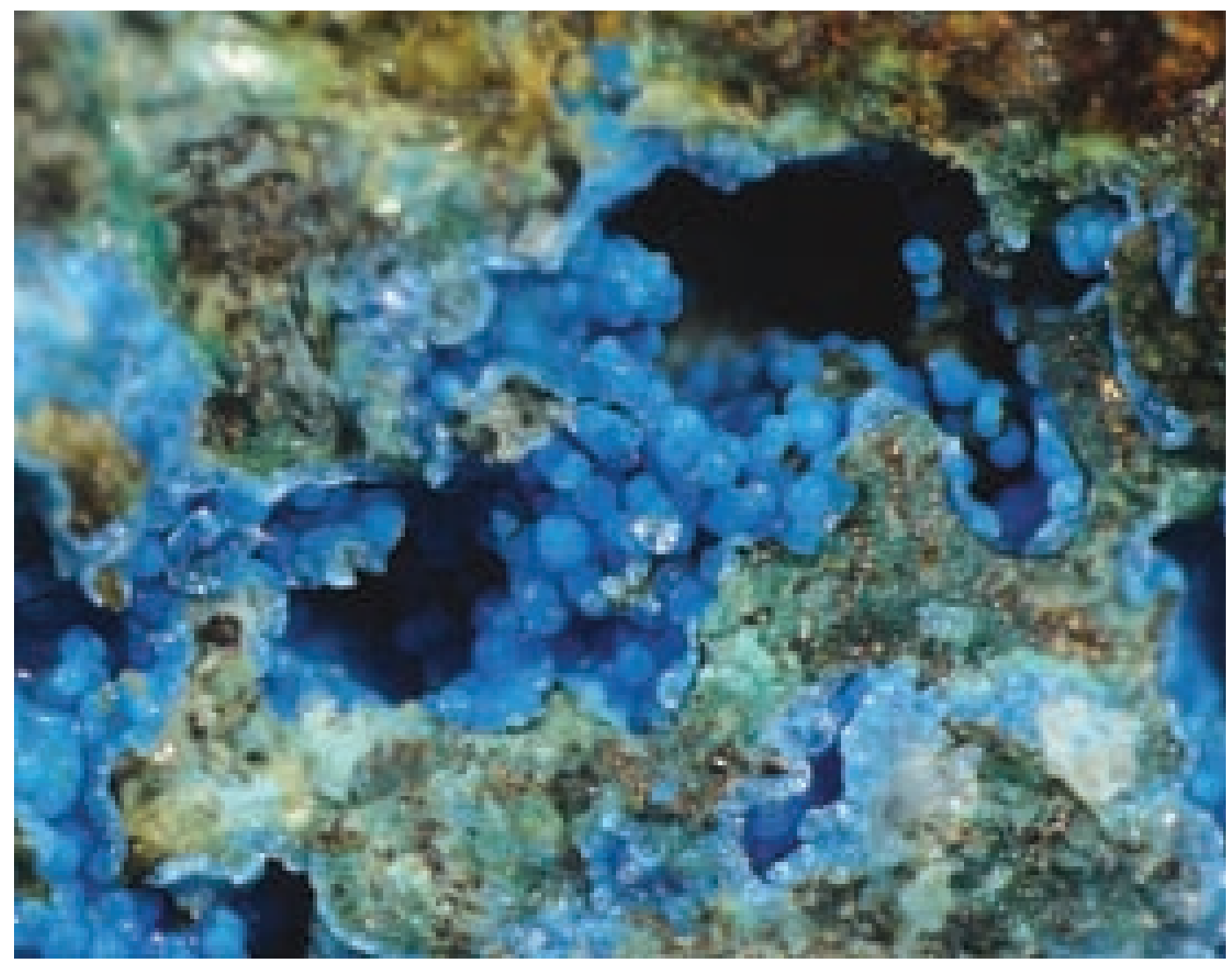




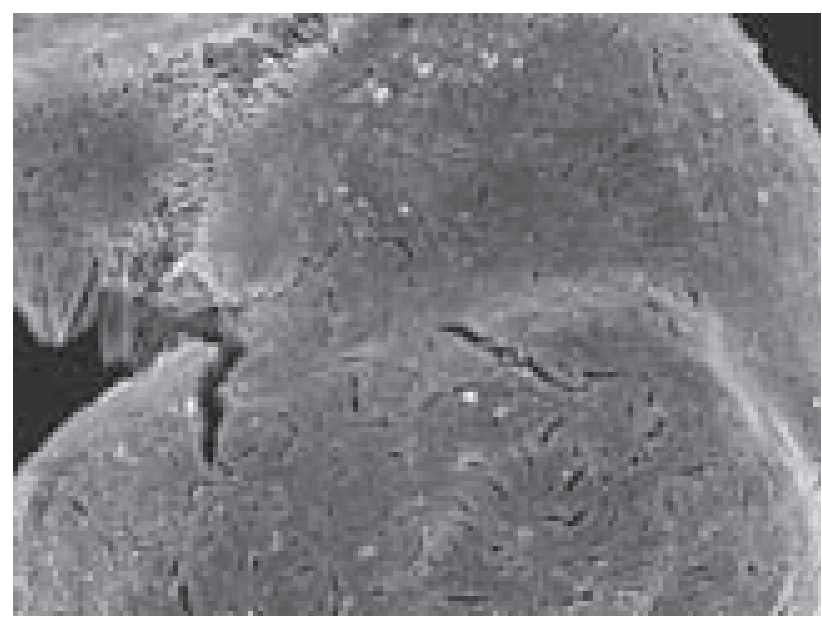

Fig. 26 Surface of semi-spherical aggregates of cyanotrichite. Huber open pit, Krásno; width of SE photo $100 \mu \mathrm{m}$. SEM Jeol JSM-6380 (J. Sejkora and J. Plášil).

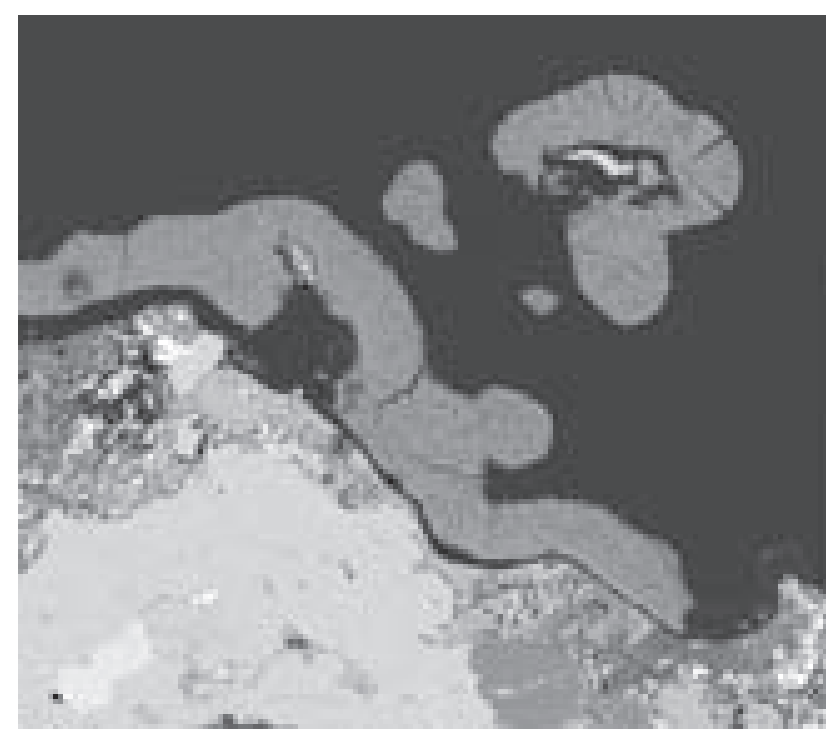

Fig. 27 Cyanotrichite coatings composed of minute tabular crystals oriented perpendicular to the surface of aggregates. The mineral is deposited on weathered gangue composed of limonite and chalcopyrite (grey) with stannite inclusions (very light grey). BSE photo, Cameca SX100 (J. Sejkora, R. Škoda).

Table 18 Chemical composition of cyanotrichite (in wt. \%)

\begin{tabular}{|l|rcc|}
\hline & mean*1 & range*1 & $* 2$ \\
\hline $\mathrm{CaO}$ & 0.05 & $0.02-0.09$ & \\
$\mathrm{CuO}$ & 54.56 & $53.05-57.34$ & 49.83 \\
$\mathrm{ZnO}$ & 0.07 & $0.05-0.09$ & \\
$\mathrm{Al}_{2} \mathrm{O}_{3}$ & 17.62 & $16.81-18.09$ & 15.82 \\
$\mathrm{Fe}_{2} \mathrm{O}_{3}$ & 0.50 & $0.43-0.58$ & \\
$\mathrm{SiO}_{2}$ & 0.22 & $0.16-0.35$ & \\
$\mathrm{As}_{2} \mathrm{O}_{5}$ & 0.11 & $0.00-0.29$ & \\
$\mathrm{SO}_{3}$ & 12.27 & $11.99-12.55$ & 12.43 \\
$\mathrm{~F}$ & 0.52 & $0.48-0.57$ & \\
$\mathrm{H}_{2} \mathrm{O}^{*}$ & 22.94 & & 22.37 \\
$-\mathrm{F}=\mathrm{O}$ & 0.22 & & \\
total & 108.58 & & 100.00 \\
\hline
\end{tabular}

$* \mathrm{H}_{2} \mathrm{O}$ content calculated from the ideal formula $\mathrm{Cu}_{4} \mathrm{Al}_{2}\left(\mathrm{SO}_{4}\right)(\mathrm{OH})_{12}$. $2 \mathrm{H}_{2} \mathrm{O}$ and charge balance.

* 1 mean and range of 3 spot analyses

$* 2$ composition calculated from ideal formula $\mathrm{Cu}_{4} \mathrm{Al}_{2}\left(\mathrm{SO}_{4}\right)(\mathrm{OH})_{12} \cdot 2 \mathrm{H}_{2} \mathrm{O}$ ly up to $0.16 a p f u$. This element probably enters the $\left(\mathrm{SO}_{4}\right)$ site, as in the related mineral khaidarkanite, and does not substitute for the $(\mathrm{OH})$ group. The empirical formula for cyanotrichite from Krásno, based on $18(\mathrm{O}, \mathrm{OH})$, is $\mathrm{Cu}_{3.99}\left(\mathrm{Al}_{2.01} \mathrm{Fe}_{0.03}\right)_{\Sigma 2.04}\left[\left(\mathrm{SO}_{4}\right)_{0.89} \mathrm{~F}_{0.16}\left(\mathrm{SiO}_{4}\right)_{0.02}\left(\mathrm{AsO}_{4}\right)_{0.01}\right]_{\Sigma 1.08}(\mathrm{OH})_{12.09}$ $2.00 \mathrm{H}_{2} \mathrm{O}$.

\section{Devilline $\mathrm{CaCu}_{4}\left(\mathrm{SO}_{4}\right)_{2}(\mathrm{OH})_{6} \cdot 3 \mathrm{H}_{2} \mathrm{O}$}

Korbel (1991) described devilline from the VII ${ }^{\text {th }}$ level of the Schnöd stock as recently formed coatings of a deep blue colour in mine adits. He also presented X-ray powder diffraction data and spectral analysis showing $\mathrm{Zn}$ ( $>1$ wt. \%). This indicates compositions in the series devilline-serpierite.

The present study confirmed the occurrence of devilline at the VIII ${ }^{\text {th }}$ level of the Schnöd stock and from parts of the Schnöd stock exposed by surface workings. The mineral occurs as thin compact coatings of green blue colour, tending to crystalline crusts. It was identified by $\mathrm{X}$-ray powder diffraction.

\section{Dussertite $\mathrm{BaFe}_{3}^{3+}\left(\mathrm{AsO}_{4}\right)_{2}(\mathrm{OH})_{5}$}

Dussertite has been found in the Huber open pit as powdery to earthy coatings of a buff white colour, and as ochre brown and white coatings, which represent a mixture of kaolinite and limonite. The coatings cover surfaces of fractures in quartz, several $\mathrm{cm}^{2}$ in size. Dussertite was identified by X-ray powder diffraction. Its refined unit-cell parameters correspond to the published data for this species (Table 20). The presence of Ba, As and $\mathrm{Fe}$ as the main elements has been proved by ED analysis.

An anomalous W-rich dussertite (Fig. 28) occurs in several specimens of strongly weathered quartz-rich greisen. It forms yellow very fine-grained or powdery coatings, up to 2 by $5 \mathrm{~cm}$ in size. The surface of dussertite aggregates is irregular in shape, locally with small groups of bright yellow green, trigonal dussertite crystals, up to $0.1 \mathrm{~mm}$ in diameter (Figs 29, 30). The aggregates have earthy appearance and crystals show a strong vitreous lustre. The X-ray powder diffraction data (Table 19) and the refined unit-cell parameters (Table 20) correspond to those of dussertite.

The quantitative chemical composition of W-rich dussertite (Table 21) indicates that it corresponds to a member of the crandallite group dominated by $\mathrm{Ba}, \mathrm{Fe}$ and As. In addition to minor contents of $\mathrm{Ca}, \mathrm{Sr}, \mathrm{Al}, \mathrm{Bi}$ and $\mathrm{P}$, expactable in crandallite-type species, elevated W content up to 0.20 apfu, unknown in minerals of this group, has been found. Tungsten probably enters the anion group of dussertite, but the small number of analyses does not allow to statistically evaluate $\mathrm{W} / \mathrm{M}^{2+, 3+}$, $\mathrm{W} / \mathrm{M}^{3+}$ and $\mathrm{W} /$ anion correlations, which may clarify crystallochemical position of $\mathrm{W}$. The empirical formula for W-rich dussertite based on $13(\mathrm{O}, \mathrm{OH})$ is $\left(\mathrm{Ba}_{0.84} \mathrm{Ca}_{0.04} \mathrm{Zn}_{0.04} \mathrm{Cu}_{0.03} \mathrm{Sr}_{0.01}\right)_{\Sigma 0.96}\left(\mathrm{Fe}_{2.65} \mathrm{Al}_{0.31}\right)_{\Sigma 2.96}\left[\left(\mathrm{AsO}_{4}\right)_{1.62}\right.$ 
Table 19 X-ray powder diffraction data of W-rich dussertite

\begin{tabular}{|c|c|c|c|c|c|c|c|c|c|c|c|c|c|c|}
\hline$I_{r e l}$ & $d$ & $h$ & $k$ & $l$ & $I_{r e l}$ & $d$ & $h$ & $k$ & $l$ & $I_{r e l}$ & $d$ & $h$ & $k$ & $l$ \\
\hline 27 & 6.001 & 1 & 0 & 1 & 28 & 1.8469 & 2 & 2 & 0 & 11 & 1.4363 & 0 & 3 & 9 \\
\hline 10 & 5.160 & 0 & 1 & 2 & 9 & 1.8044 & 2 & 0 & 8 & 9 & 1.3966 & 4 & 1 & 0 \\
\hline 29 & 3.693 & 1 & 1 & 0 & 4 & 1.7655 & 1 & 3 & 1 & 9 & 1.3966 & 1 & 4 & 0 \\
\hline 11 & 3.610 & 1 & 0 & 4 & 4 & 1.7655 & 3 & 1 & -1 & 13 & 1.3578 & 4 & 1 & -3 \\
\hline 19 & 3.143 & 0 & 2 & 1 & 13 & 1.7371 & 2 & 1 & 7 & 13 & 1.3578 & 1 & 4 & 3 \\
\hline 100 & 3.119 & 1 & 1 & 3 & 13 & 1.7371 & 1 & 2 & -7 & 13 & 1.3578 & 1 & 4 & -3 \\
\hline 100 & 3.119 & 1 & 1 & -3 & 17 & 1.7193 & 1 & 1 & 9 & 13 & 1.3578 & 4 & 1 & 3 \\
\hline 16 & 3.004 & 2 & 0 & 2 & 17 & 1.7193 & 1 & 1 & -9 & 10 & 1.3160 & 1 & 0 & 13 \\
\hline 41 & 2.913 & 0 & 0 & 6 & 10 & 1.6869 & 1 & 0 & 10 & 10 & 1.2654 & 2 & 3 & -7 \\
\hline 23 & 2.581 & 0 & 2 & 4 & 9 & 1.6210 & 2 & 1 & -8 & 10 & 1.2624 & 3 & 2 & 7 \\
\hline 13 & 2.3914 & 1 & 2 & -1 & 9 & 1.6210 & 1 & 2 & 8 & 9 & 1.2051 & 3 & 3 & -3 \\
\hline 13 & 2.3914 & 2 & 1 & 1 & 7 & 1.5928 & 0 & 4 & 1 & 9 & 1.2051 & 3 & 3 & 3 \\
\hline 54 & 2.3263 & 1 & 0 & 7 & 9 & 1.5732 & 0 & 4 & 2 & 10 & 1.1757 & 2 & 1 & 13 \\
\hline 15 & 2.2876 & 1 & 1 & 6 & 16 & 1.5599 & 2 & 2 & -6 & 10 & 1.1757 & 1 & 2 & -13 \\
\hline 15 & 2.2876 & 1 & 1 & -6 & 16 & 1.5599 & 2 & 2 & 6 & 8 & 1.1649 & 2 & 4 & 4 \\
\hline 9 & 2.1332 & 3 & 0 & 0 & 23 & 1.5340 & 0 & 2 & 10 & 8 & 1.1649 & 4 & 2 & -4 \\
\hline 10 & 2.1169 & 1 & 2 & -4 & 9 & 1.5016 & 4 & 0 & 4 & 5 & 1.1636 & 2 & 0 & -14 \\
\hline 10 & 2.1169 & 2 & 1 & 4 & 12 & 1.4475 & 3 & 1 & -7 & 9 & 1.1436 & 2 & 2 & -12 \\
\hline 33 & 2.0025 & 0 & 3 & 3 & 12 & 1.4475 & 1 & 3 & 7 & 9 & 1.1436 & 2 & 2 & 12 \\
\hline 9 & 1.9425 & 0 & 0 & 9 & 12 & 1.4363 & 3 & 0 & 9 & & & & & \\
\hline
\end{tabular}

Table 20 Unit-cell parameters for dussertite (for trigonal space group $R-3 m)$

\begin{tabular}{|l|ccc|}
\hline & $\begin{array}{c}\text { W-rich dussertite } \\
\text { this paper }\end{array}$ & $\begin{array}{r}\text { dussertite } \\
\text { this paper }\end{array}$ & $\begin{array}{c}\text { Sb-rich dussertite } \\
\text { Kolitsch } \text { et al. }(1999)\end{array}$ \\
\hline $\mathrm{a}[\AA]$ & $7.3875(5)$ & $7.3884(4)$ & $7.410(3)$ \\
$\mathrm{c}[\AA]$ & $17.484(1)$ & $17.5013(9)$ & $17.484(4)$ \\
$\mathrm{V}\left[\AA^{3}\right]$ & $826.4(1)$ & 827.4 & $831.3(3)$ \\
\hline
\end{tabular}

$\left.\left(\mathrm{WO}_{4}\right)_{0.19}\left(\mathrm{PO}_{4}\right)_{0.18}\left(\mathrm{SiO}_{4}\right)_{0.17}\right]_{\Sigma 2.16}(\mathrm{OH})_{4.32}$. The rather low totals of the chemical analyses (89.97-92.59 wt. \%) are probably caused by porosity of the very fine-grained dussertite aggregates. A detailed analysis of ED spectra did not indicate the presence of other elements with $Z>8$. A possible presence of $\mathrm{Mg}$ was tested using WD spectra with no positive results. Alternatively, $\mathrm{H}_{2} \mathrm{O}$ content in this

Fig. 28 Coatings of W-rich dussertite. Huber stock, Krásno; width of photo $2.3 \mathrm{~cm}$. Nicon SMZ1500 microphotography (J. \& E. Sejkora).

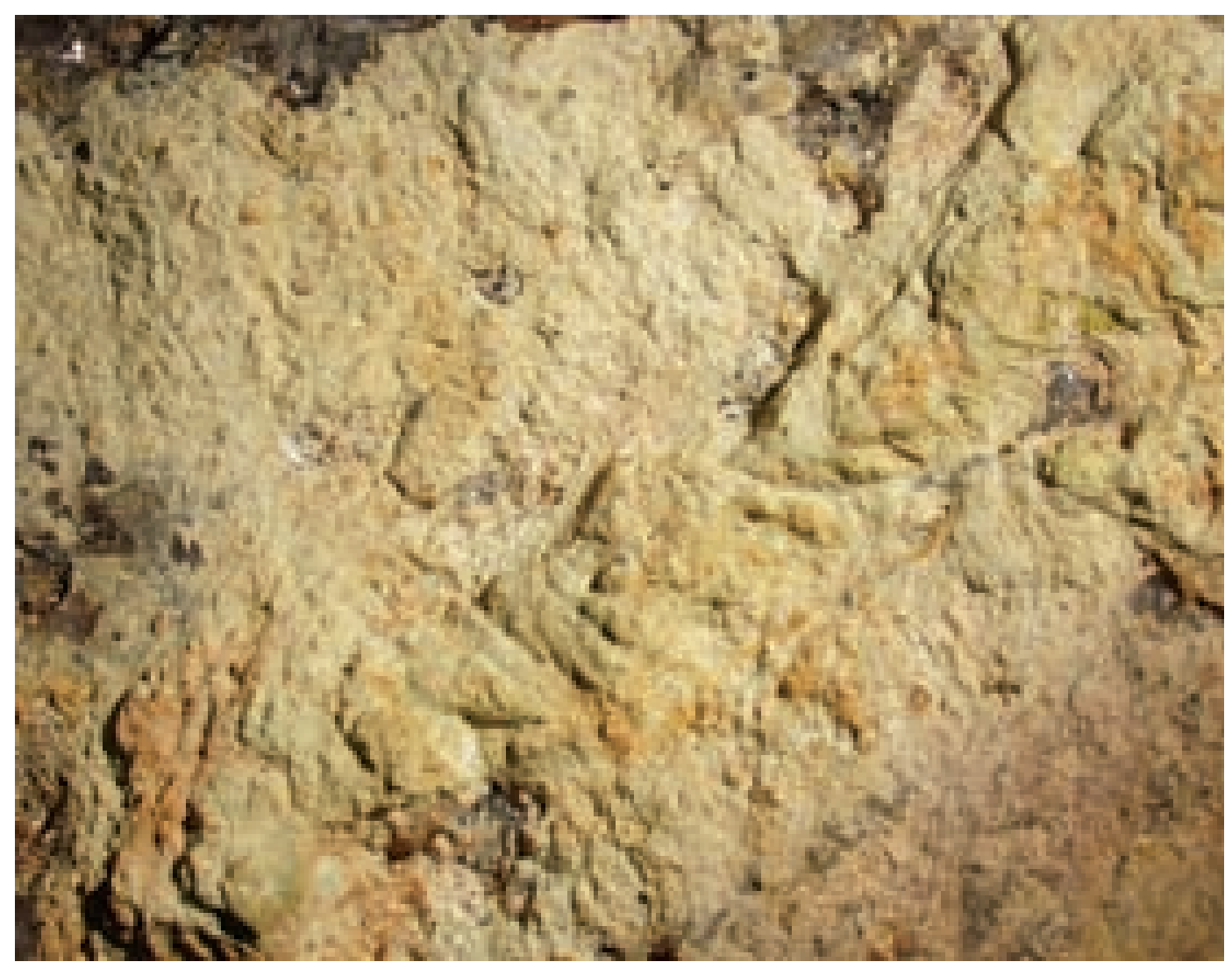




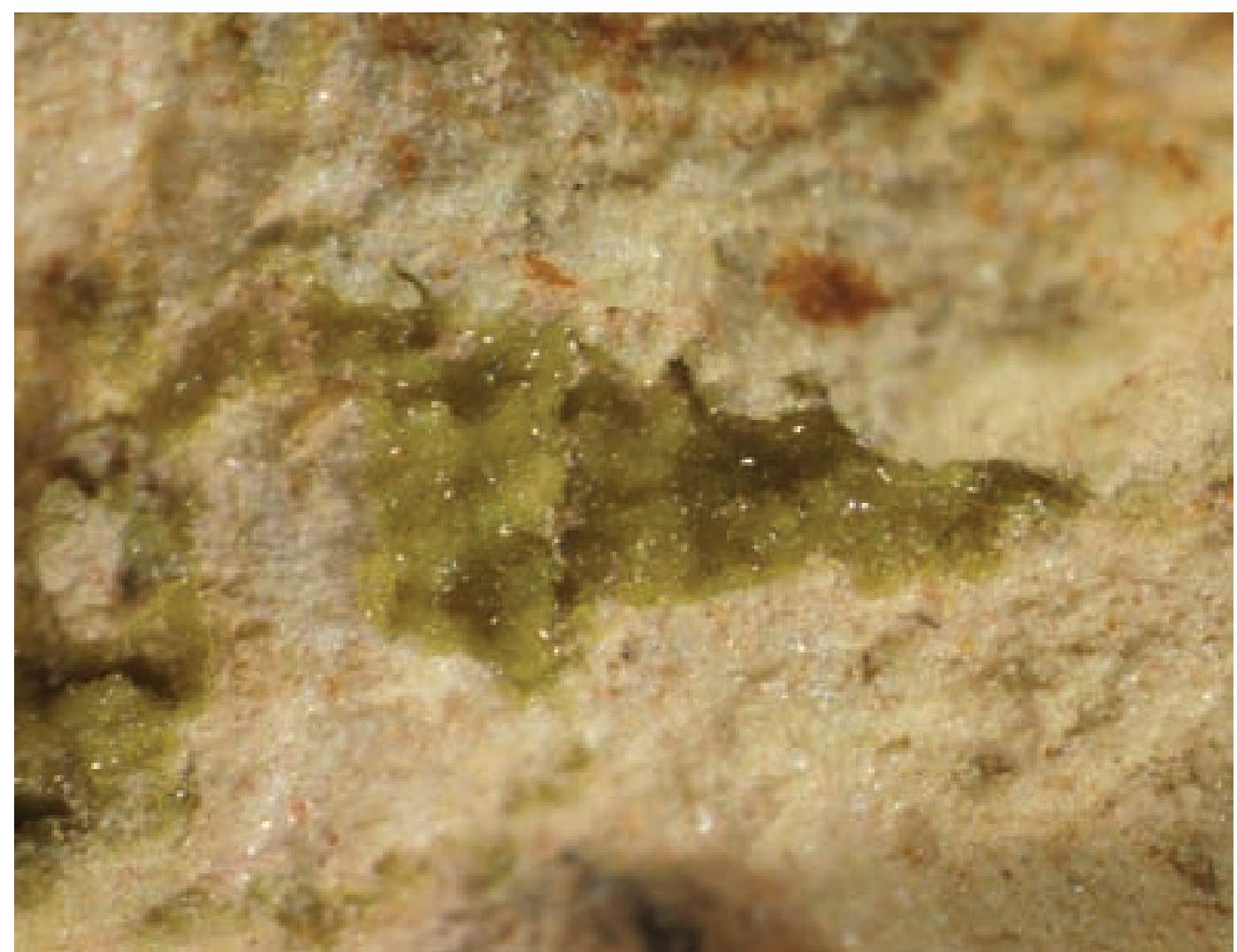

Fig. 29 Group of small trigonal crystals of W-rich dussertite. Huber stock, Krásno; width of photo $2 \mathrm{~mm}$. Nicon SMZ1500 microphotography (J. \& E. Sejkora).

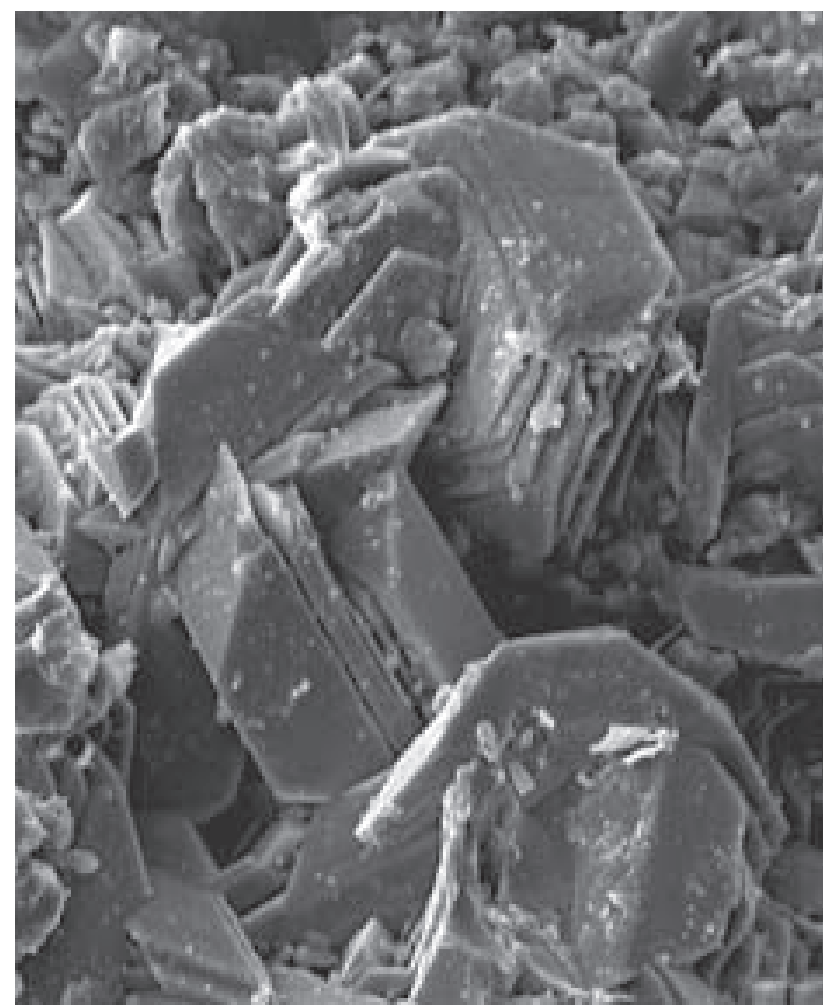

Fig. 30 Intergrowth of trigonal crystals of W-rich dussertite. Huber stock, Krásno; width of SE photo $70 \mu \mathrm{m}$. SEM Jeol JSM-6380 (J. Sejkora and J. Plášil).
Table 21 Chemical composition of dussertite (in wt. \%)

\begin{tabular}{|l|rcr|}
\hline & mean*1 & range*1 & $* 2$ \\
\hline $\mathrm{CaO}$ & 0.31 & $0.23-0.40$ & \\
$\mathrm{BaO}$ & 17.68 & $16.64-18.57$ & 22.96 \\
$\mathrm{SrO}$ & 0.21 & $0.14-0.35$ & \\
$\mathrm{CuO}$ & 0.33 & $0.31-0.35$ & \\
$\mathrm{ZnO}$ & 0.41 & $0.28-0.51$ & \\
$\mathrm{Al}_{2} \mathrm{O}_{3}$ & 2.14 & $1.66-2.54$ & \\
$\mathrm{Fe}_{2} \mathrm{O}_{3}$ & 24.09 & $27.91-31.45$ & 35.87 \\
$\mathrm{Bi}_{2} \mathrm{O}_{3}$ & 0.17 & $0.00-0.30$ & \\
$\mathrm{SiO}_{2}$ & 1.42 & $1.04-2.02$ & \\
$\mathrm{As}_{2} \mathrm{O}_{5}$ & 25.59 & $24.36-26.82$ & 34.42 \\
$\mathrm{P}_{2} \mathrm{O}_{5}$ & 1.79 & $0.91-2.37$ & \\
$\mathrm{SO}_{3}$ & 0.10 & $0.05-0.16$ & \\
$\mathrm{WO}_{3}$ & 5.90 & $5.32-6.51$ & \\
$\mathrm{H}_{2} \mathrm{O}^{*}$ & 5.87 & & 6.75 \\
total & 91.01 & & 100.00 \\
\hline
\end{tabular}

${ }^{*} \mathrm{H}_{2} \mathrm{O}$ content calculated from ideal formula $\mathrm{BaFe}^{3+}{ }_{3}\left(\mathrm{AsO}_{4}\right)_{2}(\mathrm{OH})_{5}$ and charge balance.

$1 *$ mean and range for 4 spot analyses.

$2 *$ theoretical composition of dussertite $\mathrm{BaFe}^{3+}{ }_{3}\left(\mathrm{AsO}_{4}\right)_{2}(\mathrm{OH})_{5}$.

dussertite higher than indicated by the ideal formula $\mathrm{BaFe}^{3+}{ }_{3}\left(\mathrm{AsO}_{4}\right)_{2}(\mathrm{OH})_{5}$ could be considered; for $\mathrm{M}^{2+}$ dominated members of the crandallite group the group $\left(\mathrm{XO}_{4}\right)(\mathrm{OH})_{5} . \mathrm{H}_{2} \mathrm{O}$ [or alternatively $\left.\left(\mathrm{XO}_{4}\right)\left(\mathrm{XO}_{3} \mathrm{OH}\right)(\mathrm{OH})_{6}\right]$ is characteristic. Even in this case, the calculated $\mathrm{H}_{2} \mathrm{O}$ content was $8.38 \mathrm{wt} . \%$ and the analysis total only 93.52 wt.\%. 


\section{Goethite $\mathrm{Fe}^{3+} \mathrm{O}(\mathrm{OH})$}

Goethite was reported by Drozen (1967), Tacl - Blüml (1974), Mach (1979) and Korbel (1991). It occurs in the whole zone of supergene alteration associated with other supergene minerals as one of the youngest minerals. Spheroidal radiating aggregates of brown red to greyish red colour are most common on rock fracture surfaces. Rare thin tabular crystals of brown colour, up to $1 \mathrm{~cm}$ long, occur in cavities of quartz gangue.

\section{Greenockite CdS}

Greenockite has been found in the central part of the Huber stock in the Stannum mine, along fractures of a quartz veinlet in greisenized granite. The mineral forms yellow to red orange compact to powdery coatings, tending to minute spheroidal aggregates. The crystal shape is not visible even at the highest SEM magnifications. This may indicate that greenockite formed by a rapid precipitation of amorphous CdS. It is supported by broad diffractions in the X-ray diffraction pattern. The refined unit-cell data (Table 22) based on such X-ray diffraction pattern corresponds to the published values. The formation of greenockite probably reflects relatively high contents of $\mathrm{Cd}$ (up to $0.1 \mathrm{wt}$. \%) in sphalerite disseminated in the surrounding greisen.

Table 22 Unit-cell parameters of greenockite (for hexagonal space group $P 6_{3} m c$ )

\begin{tabular}{|l|cc|}
\hline & $\begin{array}{c}\text { Huber stock } \\
\text { this paper }\end{array}$ & $\begin{array}{c}\text { synt. } \\
\text { Yeh } \text { et al. }(1992)\end{array}$ \\
\hline $\mathrm{a}[\AA]$ & $4.100(3)$ & 4.121 \\
$\mathrm{c}[\AA]$ & $6.734(6)$ & 6.682 \\
$\mathrm{~V}\left[\AA^{3}\right]$ & 98.03 & 98.27 \\
\hline
\end{tabular}

\section{Gypsum $\mathrm{CaSO}_{4} \cdot 2 \mathrm{H}_{2} \mathrm{O}$}

Krejčí (1855) described the first gypsum occurrence at Horní Slavkov. Later on, gypsum was identified by $\mathrm{X}$-ray powder diffraction and a spectral analysis (Drozen 1967). Up to several cm long, colourless, transparent and perfectly formed crystals were collected recently in clay of a fault zone. Gypsum was identified by X-ray powder diffraction data.

\section{Hentschelite $\mathrm{CuFe}_{2}^{3+}{ }_{2}\left(\mathrm{PO}_{4}\right)_{2}(\mathrm{OH})_{2}$}

Hentschelite occurs as a very rare mineral (only two samples were found) at the Huber open pit. It forms light green powdery to finely crystalline coatings, up to $2 \mathrm{~cm}^{2}$ in size, in cavity of corroded beige pink fluorapatite. It is associated with transparent, slightly brownish crystals of leucophosphite.
X-ray powder diffraction data (Table 23) correspond to data for hentschelite from Reichenbach, Germany (Sieber et al. 1987b) and the refined unit-cell parameters to the published data for this species (Table 24).

Jarosite $\mathrm{KFe}_{3}^{3+}\left(\mathrm{SO}_{4}\right)_{2}(\mathrm{OH})_{6}$

Slavík (1903) described this mineral from Horní Slavkov for the first time; however, the accurate original location is unknown. Korbel (1991) confirmed presence of jarosite on a single sample of greisen from Vysoký Kámen. It occurs as ochre yellow earthy nodules, up to $5 \mathrm{~mm}$ large. Korbel (1991) presented X-ray powder diffraction data and unit-cell parameters (Table 25); these values indicate a possible isomorphic substitution (K-Na, $\mathrm{Fe}-\mathrm{Al}$, etc.) in cation positions.

\section{Kaňkite $\mathrm{Fe}^{3+} \mathrm{AsO}_{4} \cdot 3.5 \mathrm{H}_{2} \mathrm{O}$}

It has been identified in samples from the Huber open pit associated with scorodite and secondary cassiterite. Kaňkite forms light green to yellow brown botryoidal aggregates of spheres, up to $0.5 \mathrm{~mm}$ in diameter (Fig. 31), constituting coatings to several $\mathrm{cm}^{2}$ in size. It occurs on quartz crystals or directly on weathered arsenopyrite. The mineral was identified by X-ray powder diffraction data. The refined unit-cell parameters of kaňkite (Table 26) correspond to the published values.

\section{Langite $\mathrm{Cu}_{4}\left(\mathrm{SO}_{4}\right)(\mathrm{OH})_{6} \cdot 2 \mathrm{H}_{2} \mathrm{O}$}

Langite occurs in samples from the Huber open pit associated with scorodite. It forms whitish to white blue coatings of minute spheres, up to $0.1 \mathrm{~mm}$ in diameter, tending to powdery coatings of a velvety appearance. The coatings consist of randomly intergrown tabular crystals, about $0.2 \mathrm{~mm}$ in size (Fig. 32). Langite has also been identified from old dump near ventilation shaft of the Stannum mine. Here it forms light blue glassy crystalline coatings in association with devilline, malachite and limonite on surface of a weathered vein with chalcopyrite. Langite was identified by X-ray powder diffraction data.

\section{Libethenite $\mathrm{Cu}_{2}\left(\mathrm{PO}_{4}\right)(\mathrm{OH})$}

Rosický (1916) published the first, though not necessarily firmly reliable description of libethenite from Horní Slavkov. Kratochvíl (1963) described grass green mineral, likely libethenite, forming abundant druses and coatings and intergrown with nacrite. Libethenite forms grass green minute crystals with a vitreous lustre, constituting fine-grained aggregates. The mineral in part penetrates aggregates of a clay mineral similar to kaolinite (Tacl Blüml 1974). Korbel (1991) described from the Huber open pit two morphologically distinct types of libethen- 
Table 23 X-ray powder diffraction pattern of hentschelite

\begin{tabular}{|c|c|c|c|c|c|c|c|c|c|c|c|c|c|c|}
\hline$I_{r e l}$ & $d$ & $h$ & $k$ & $l$ & $I_{r e l}$ & $d$ & $h$ & $k$ & $l$ & $I_{r e l}$ & $d$ & $h$ & $k$ & $l$ \\
\hline 12 & 5.250 & 0 & 1 & 1 & 11 & 2.2524 & 1 & 3 & 0 & 2 & 1.6071 & 1 & 3 & 3 \\
\hline 30 & 4.944 & 0 & 1 & 1 & 4 & 2.2330 & -2 & 1 & 3 & 2 & 1.6071 & 3 & 1 & 3 \\
\hline 10 & 4.849 & 1 & 1 & 0 & 7 & 2.2191 & 2 & 2 & 1 & 10 & 1.6020 & -1 & 2 & 4 \\
\hline 71 & 4.790 & -1 & 1 & 1 & 18 & 2.2063 & -3 & 1 & 1 & 2 & 1.5985 & 0 & 0 & 4 \\
\hline 9 & 4.061 & 0 & 2 & 0 & 4 & 2.1406 & 1 & 3 & 1 & 2 & 1.5965 & -3 & 3 & 3 \\
\hline 5 & 3.899 & 0 & 2 & 0 & 4 & 2.1406 & 3 & 1 & 1 & 6 & 1.5596 & -3 & 2 & 4 \\
\hline 6 & 3.875 & 1 & 1 & 1 & 9 & 2.1225 & 1 & 3 & 1 & 9 & 1.5481 & 4 & 0 & 0 \\
\hline 12 & 3.678 & 1 & 0 & 1 & 44 & 2.1074 & -1 & 3 & 2 & 2 & 1.5385 & -4 & 2 & 3 \\
\hline 11 & 3.497 & 0 & 2 & 1 & 9 & 2.0851 & -2 & 3 & 1 & 10 & 1.5241 & 3 & 3 & 1 \\
\hline 21 & 3.441 & 0 & 0 & 2 & 3 & 2.0563 & 1 & 2 & 2 & 8 & 1.49526 & -2 & 4 & 3 \\
\hline 100 & 3.329 & 0 & 2 & 1 & 3 & 2.0559 & 0 & 1 & 3 & 3 & 1.48192 & -3 & 4 & 2 \\
\hline 98 & 3.326 & 1 & 1 & 1 & 13 & 2.0355 & 2 & 2 & 1 & 2 & 1.47995 & -2 & 3 & 4 \\
\hline 45 & 3.299 & 1 & 2 & 0 & 14 & 2.0335 & -1 & 2 & 3 & 5 & 1.47899 & 0 & 2 & 4 \\
\hline 47 & 3.280 & -1 & 2 & 1 & 9 & 1.9954 & 3 & 1 & 0 & 7 & 1.46879 & 0 & 5 & 2 \\
\hline 15 & 3.269 & -1 & 1 & 2 & 18 & 1.9688 & -3 & 2 & 2 & 14 & 1.46735 & 1 & 3 & 3 \\
\hline 12 & 3.197 & 0 & 0 & 2 & 40 & 1.9374 & 2 & 2 & 2 & 2 & 1.44946 & -4 & 3 & 2 \\
\hline 14 & 3.187 & -2 & 1 & 1 & 3 & 1.8845 & 3 & 1 & 2 & 2 & 1.44733 & 3 & 3 & 1 \\
\hline 33 & 3.168 & 0 & 1 & 2 & 3 & 1.8845 & 1 & 3 & 2 & 4 & 1.44618 & 2 & 3 & 3 \\
\hline 27 & 3.096 & 2 & 0 & 0 & 3 & 1.8646 & 0 & 4 & 1 & 4 & 1.44618 & 3 & 2 & 3 \\
\hline 15 & 3.069 & 1 & 2 & 0 & 11 & 1.8559 & -1 & 4 & 1 & 3 & 1.44147 & 2 & 1 & 3 \\
\hline 15 & 3.069 & 2 & 1 & 0 & 18 & 1.8389 & 2 & 0 & 2 & 4 & 1.43841 & 0 & 4 & 3 \\
\hline 11 & 3.035 & -2 & 0 & 2 & 2 & 1.7984 & 3 & 2 & 1 & 11 & 1.43100 & -1 & 5 & 2 \\
\hline 19 & 2.958 & 0 & 1 & 2 & 2 & 1.7984 & 2 & 3 & 1 & 6 & 1.42950 & 3 & 1 & 2 \\
\hline 12 & 2.878 & 2 & 1 & 0 & 5 & 1.7958 & -3 & 2 & 3 & 2 & 1.42394 & -2 & 5 & 1 \\
\hline 24 & 2.803 & 1 & 2 & 1 & 2 & 1.7898 & 2 & 1 & 2 & 2 & 1.42367 & -3 & 3 & 4 \\
\hline 24 & 2.803 & 2 & 1 & 1 & 2 & 1.7712 & 1 & 3 & 2 & 3 & 1.42298 & 3 & 3 & 2 \\
\hline 11 & 2.774 & 1 & 1 & 2 & 14 & 1.7462 & -4 & 0 & 2 & 3 & 1.42089 & -3 & 0 & 5 \\
\hline 55 & 2.707 & 0 & 3 & 0 & 6 & 1.7425 & 3 & 0 & 1 & 3 & 1.41966 & -4 & 3 & 1 \\
\hline 21 & 2.675 & 1 & 2 & 1 & 2 & 1.7226 & -3 & 3 & 1 & 9 & 1.41406 & -4 & 2 & 4 \\
\hline 4 & 2.645 & -1 & 2 & 2 & 2 & 1.7223 & 1 & 4 & 1 & 12 & 1.40761 & -4 & 3 & 3 \\
\hline 24 & 2.625 & 0 & 2 & 2 & 4 & 1.7144 & -3 & 3 & 2 & 3 & 1.39787 & -3 & 1 & 5 \\
\hline 47 & 2.601 & -2 & 2 & 1 & 4 & 1.7142 & -1 & 4 & 2 & 7 & 1.37689 & 1 & 1 & 4 \\
\hline 20 & 2.519 & 0 & 3 & 1 & 2 & 1.7142 & -1 & 1 & 4 & 5 & 1.36453 & -1 & 1 & 5 \\
\hline 31 & 2.4721 & 0 & 2 & 2 & 2 & 1.7040 & -4 & 1 & 2 & 9 & 1.34627 & 4 & 1 & 1 \\
\hline 14 & 2.4246 & 2 & 2 & 0 & 4 & 1.7006 & 3 & 1 & 1 & 2 & 1.33509 & 4 & 3 & 0 \\
\hline 27 & 2.4078 & 0 & 3 & 1 & 18 & 1.6643 & 0 & 4 & 2 & 2 & 1.33509 & 3 & 4 & 0 \\
\hline 15 & 2.3965 & 1 & 3 & 0 & 12 & 1.6631 & 2 & 2 & 2 & 2 & 1.33499 & -3 & 2 & 5 \\
\hline 13 & 2.3948 & -2 & 2 & 2 & 17 & 1.6625 & -3 & 1 & 4 & 8 & 1.32556 & 0 & 5 & 3 \\
\hline 16 & 2.3892 & -1 & 3 & 1 & 4 & 1.6562 & -4 & 1 & 1 & 4 & 1.31773 & -5 & 1 & 1 \\
\hline 33 & 2.3834 & -1 & 0 & 3 & 8 & 1.6496 & 2 & 4 & 0 & 2 & 1.31668 & 1 & 2 & 4 \\
\hline 7 & 2.3443 & 2 & 2 & 0 & 32 & 1.6480 & 0 & 3 & 3 & 3 & 1.31066 & 4 & 3 & 1 \\
\hline 10 & 2.3115 & 1 & 1 & 2 & 8 & 1.6401 & -2 & 4 & 2 & 3 & 1.31066 & 3 & 4 & 1 \\
\hline 13 & 2.3003 & -3 & 0 & 1 & 2 & 1.6345 & -2 & 2 & 4 & 4 & 1.31041 & -4 & 3 & 4 \\
\hline 8 & 2.2821 & 2 & 1 & 1 & 6 & 1.6242 & 0 & 5 & 0 & 10 & 1.30066 & -4 & 4 & 2 \\
\hline 6 & 2.2793 & -1 & 1 & 3 & 7 & 1.6164 & 3 & 3 & 0 & & & & & \\
\hline 11 & 2.2524 & 3 & 1 & 0 & 6 & 1.6151 & 1 & 1 & 4 & & & & & \\
\hline
\end{tabular}

Table 24 Unit-cell parameters of hentschelite (for monoclinic space group $P 2, / n$ )

\begin{tabular}{|l|cc|}
\hline & $\begin{array}{c}\text { Huber stock } \\
\text { this paper }\end{array}$ & $\begin{array}{c}\text { Reichenbach } \\
\text { Sieber } \text { et al. }(1987 \mathrm{a})\end{array}$ \\
\hline $\mathrm{a}[\AA]$ & $6.987(6)$ & $6.984(3)$ \\
$\mathrm{b}[\AA]$ & $7.797(6)$ & $7.786(3)$ \\
$\mathrm{c}[\AA]$ & $7.214(6)$ & $7.266(3)$ \\
$\mathrm{B}\left[{ }^{\circ}\right]$ & $117.59(6)$ & $117.68(2)$ \\
$\mathrm{V}\left[\AA^{3}\right]$ & 348.3 & 349.89 \\
\hline
\end{tabular}

Ta b le 25 Unit-cell parameters of jarosite (for trigonal space group $R-3 m$ )

\begin{tabular}{|l|cc|}
\hline & Huber stock & synt. \\
& Korbel (1991) & Menchetti - Sabelli (1976) \\
\hline $\mathrm{a}[\AA]$ & $7.257(3)$ & $7.315(2)$ \\
$\mathrm{c}[\AA]$ & $17.123(12)$ & $17.224(6)$ \\
$\mathrm{V}\left[\AA^{3}\right]$ & 780.9 & 798.17 \\
\hline
\end{tabular}

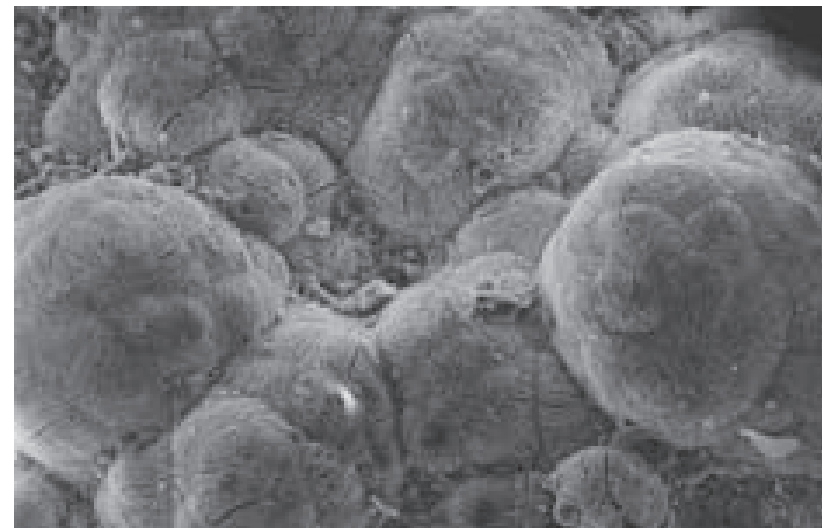

Fig. 31 Botryoidal surface of kaňkite aggregate. Huber open pit; width of SE photo $200 \mu \mathrm{m}$; SEM Tesla 320 (A. Gabašová). 
Table 26 Unit-cell parameters of kaňkite (for monoclinic cell)

\begin{tabular}{|l|cc|}
\hline & $\begin{array}{c}\text { Huber stock } \\
\text { this paper }\end{array}$ & $\begin{array}{c}\text { Kaňk near Kutná Hora } \\
\text { Čech et al. }(1976)\end{array}$ \\
\hline $\mathrm{a}[\AA]$ & $18.72(1)$ & $18.803(15)$ \\
$\mathrm{b}[\AA]$ & $17.503(9)$ & $17.490(18)$ \\
$\mathrm{c}[\AA]$ & $7.646(4)$ & $7.633(5)$ \\
$\mathrm{B}\left[{ }^{\circ}\right]$ & $92.76(8)$ & $92.71(5)$ \\
$\mathrm{V}\left[\AA^{3}\right]$ & 2502.3 & 2507.4 \\
\hline
\end{tabular}

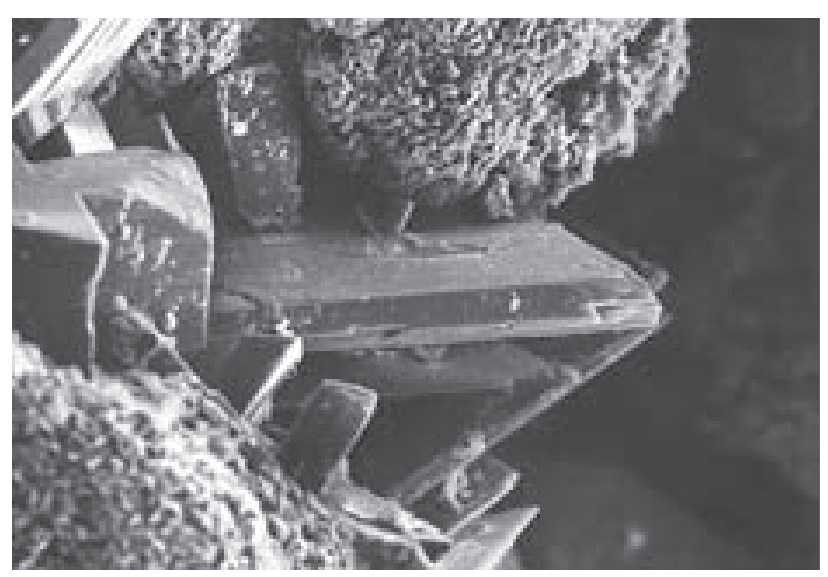

Fig. 32 Minute tabular langite crystals. Huber open pit, Krásno; width of SE photo $500 \mu \mathrm{m}$; SEM Tesla 320 (A. Gabašová).
Table 27 Unit-cell parameters of libethenite (for orthorhombic space group Pnnm)

\begin{tabular}{|l|cc|}
\hline & $\begin{array}{c}\text { Krásno } \\
\text { Korbel }(1991)\end{array}$ & $\begin{array}{c}\text { synt. } \\
\text { Yakubovich }- \text { Mel'nikov (1993) }\end{array}$ \\
\hline $\mathrm{a}[\AA]$ & $8.229(10)$ & $8.071(2)$ \\
$\mathrm{b}[\AA]$ & $8.445(20)$ & $8.403(4)$ \\
$\mathrm{c}[\AA]$ & $5.896(2)$ & $5.898(3)$ \\
$\mathrm{V}\left[\AA^{3}\right]$ & 409.7 & 400.01 \\
\hline
\end{tabular}

ite - the first one forms green pseudocubic/octahedral crystals, up to $1 \mathrm{~mm}$ in size.

The second one is represented by black-green crystalline aggregates consisting of tiny orthorhombic crystals. Korbel (1991) used for libethenite identification spectral analysis, optical properties (biaxial negative, $\mathrm{N}_{\mathrm{g}}=$ $\left.1.788(2), \mathrm{N}_{\mathrm{m}}=1.742(3), \mathrm{N}_{\mathrm{p}}=1.703(3)\right)$, X-ray powder diffraction data and refined unit-cell parameters (Table 27). Somewhat elevated values of the unit-cell parameters indicate an increased content of As (olivenite component) in the samples studied by Korbel (1991).

Dipyramidal crystals of libethenite (Figs 33, 34), up to $3 \mathrm{~mm}$ long, associated with olivenite, quartz, clay minerals and corroded sulfides were relatively common in the Huber open pit. Colour varies from green to black-
Fig. 33 Libethenite crystals in quartz gangue. Huber open pit, Krásno; width of photo $4 \mathrm{~mm}$. Nicon SMZ1500 microphotography (J. \& E. Sejkora).

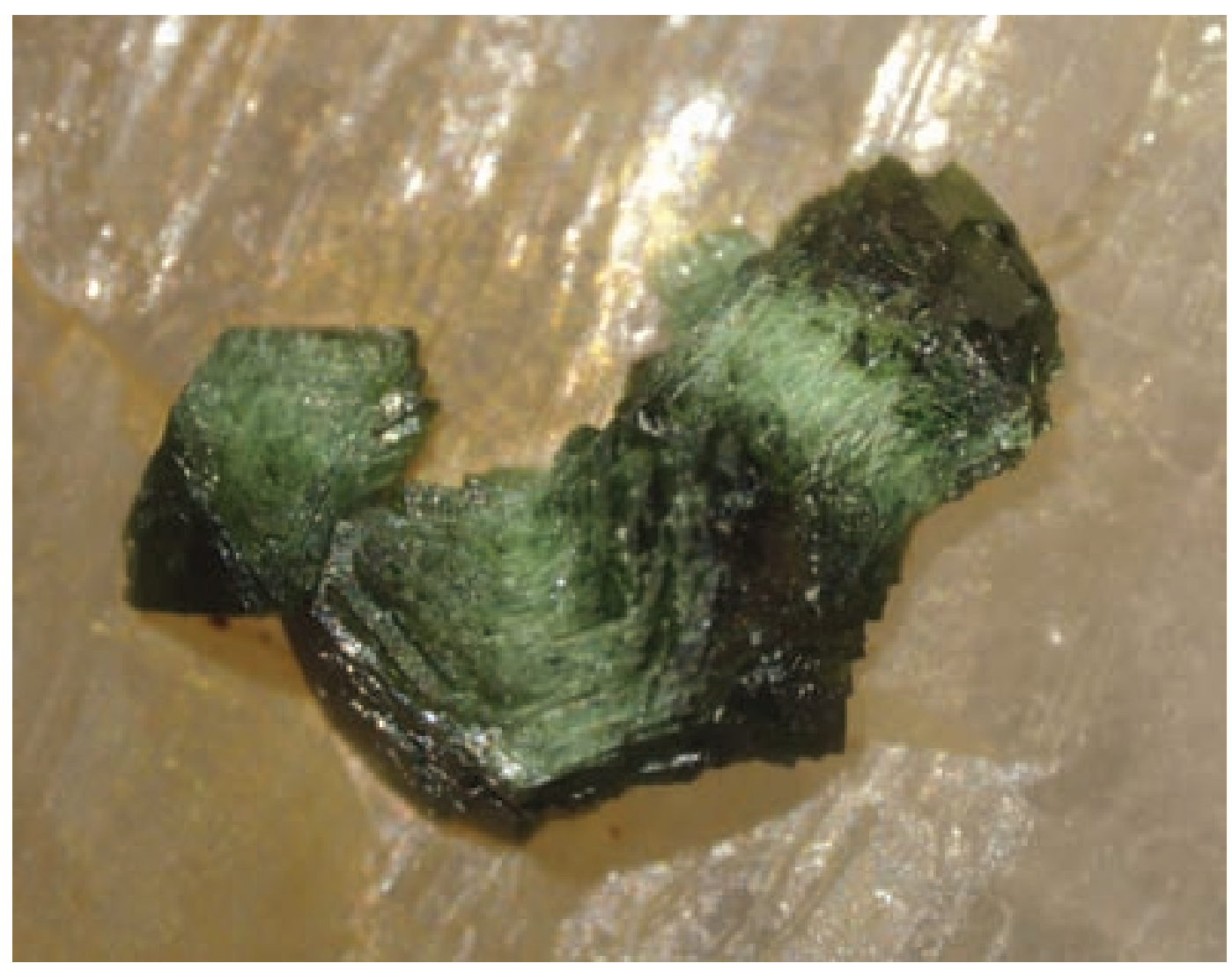




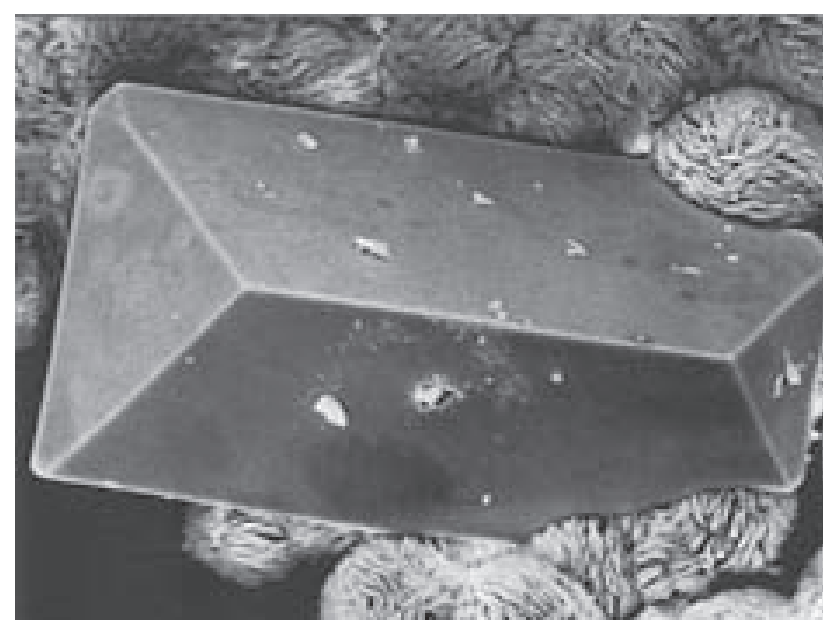

Fig. 34 Libethenite crystal. Huber open pit, Krásno; width of SE photo $500 \mu \mathrm{m}$; SEM Jeol JSM T-20 (Z. Mach).

green, lustre is usually vitreous but in association with clay minerals libethenite is often corroded. At the extraordinary level at $500 \mathrm{~m}$ a.s.1., libethenite forms light green strongly vitreous crystals, up to $1 \mathrm{~mm}$ in size, associated with olivenite, cassiterite and chalcopyrite. Libethenite specimens collected at new sites have been identified using X-ray powder diffraction and semiquantitative study of chemical composition. A typical feature of the studied specimens (Fig. 35) is a distinct compositional zoning, including substitutions $\mathrm{Cu}-\mathrm{Zn}$ and P-As. In the $\mathrm{M}^{2+}$ position, regular $\mathrm{Zn}$ contents up to $0.05-0.14$ apfu (Fig. 36) and variable but low contents of Fe (0-0.04 apfu) were found. In the anion group As contents of 0.10-0.55 apfu (Fig. 37) indicate a wide range of the libethenite (P) - olivenite (As) isomorphous series. Acicular crystals and compact aggregate from the $5^{\text {th }}$ level of the Huber mine (analysis 6 in Table 28) shows up to

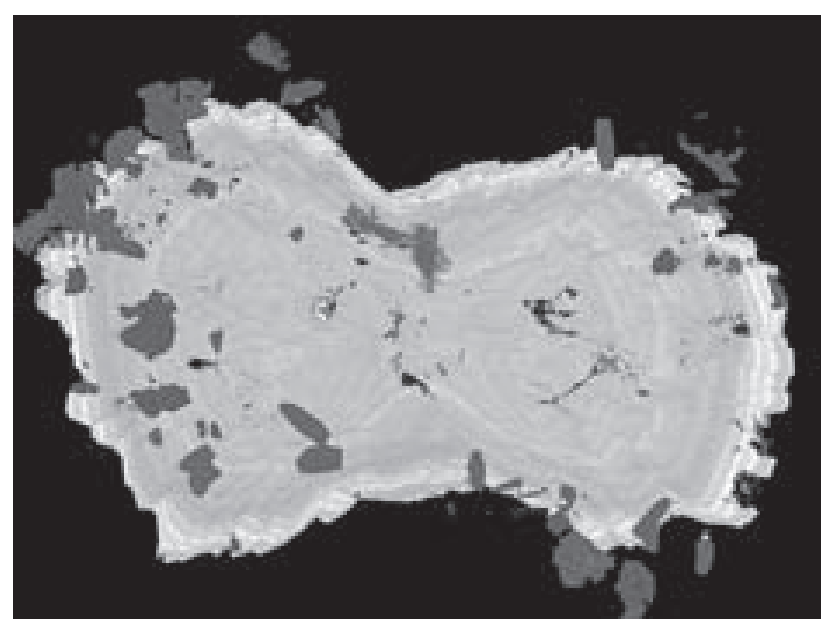

Fig. 35 Semi-spherical zoned aggregate (P-As, $\mathrm{Cu}-\mathrm{Zn})$ of libethenite at margins of fluorapatite and lighter tabular crystals of UNK6. Huber open pit, Krásno; width of BSE photo $1.2 \mathrm{~mm}$. Cameca SX100 (J. Sejkora, R. Škoda).

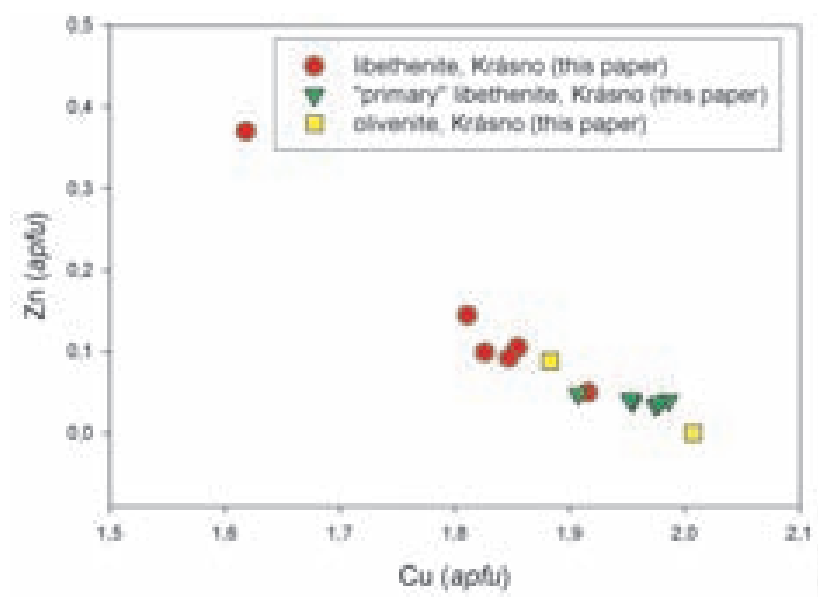

Fig. $36 \mathrm{Cu}$ vs. Zn (apfu) diagram for minerals of the libethenite-olivenite isomorphous series from Krásno.

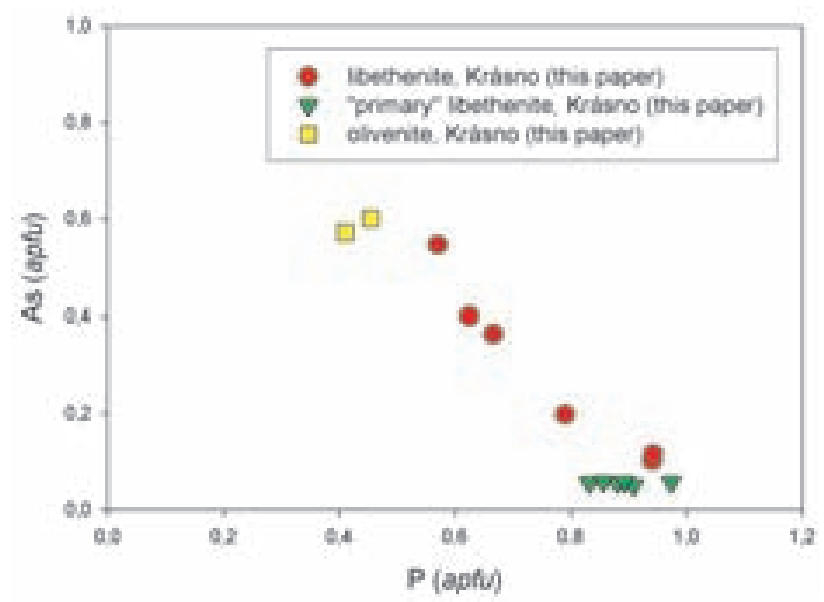

Fig. 37 P vs. As (apfu) diagram for minerals of the libethenite-olivenite isomorphous series from Krásno.

Table 28 Chemical composition of libethenite (in wt. \%)

\begin{tabular}{|l|rrrrrrr|}
\hline & \multicolumn{1}{|c}{1.} & \multicolumn{1}{c}{2.} & \multicolumn{1}{c}{3.} & \multicolumn{1}{c}{4.} & \multicolumn{1}{c}{5.} & \multicolumn{1}{c|}{6.} & 7. \\
\hline $\mathrm{CuO}$ & 58.09 & 58.38 & 58.69 & 59.02 & 53.54 & 50.02 & 66.54 \\
$\mathrm{CaO}$ & 0.05 & 0.11 & 0.08 & 0.05 & & & \\
$\mathrm{ZnO}$ & 4.75 & 3.23 & 3.40 & 1.57 & 2.73 & 11.72 & \\
$\mathrm{FeO}$ & 0.39 & 0.78 & 1.19 & & & & \\
$\mathrm{Al}_{2} \mathrm{O}_{3}$ & 0.09 & 0.19 & 0.03 & 0.19 & 0.04 & & \\
$\mathrm{P}_{2} \mathrm{O}_{5}$ & 26.92 & 26.87 & 22.32 & 18.32 & 14.74 & 17.23 & 29.69 \\
$\mathrm{As}_{2} \mathrm{O}_{5}$ & 4.71 & 5.32 & 9.05 & 16.21 & 22.89 & 17.85 & \\
$\mathrm{H}_{2} \mathrm{O}^{*}$ & 3.08 & 2.85 & 3.80 & 3.12 & 1.82 & 3.15 & 3.77 \\
total & 98.08 & 97.74 & 98.54 & 98.49 & 95.77 & 99.97 & 100.00 \\
\hline
\end{tabular}

* $\mathrm{H}_{2} \mathrm{O}$ content calculated from the ideal formula $\mathrm{Cu}_{2}\left(\mathrm{PO}_{4}\right)(\mathrm{OH})$ and charge balance.

The following empiric formulas were celculated on the basis of

$5(\mathrm{O}, \mathrm{OH})$ :

1. $\left(\mathrm{Cu}_{1.81} \mathrm{Zn}_{0.14} \mathrm{Fe}_{0.01}\right)_{\Sigma 1.96}\left[\left(\mathrm{PO}_{4}\right)_{0.94}\left(\mathrm{AsO}_{4}\right)_{0.10}\right]_{\Sigma 1.04}(\mathrm{OH})_{0.83}$

2. $\left(\mathrm{Cu}_{1.83} \mathrm{Zn}_{0.10} \mathrm{Fe}_{0.03}\right)_{\Sigma 1.96}\left[\left(\mathrm{PO}_{4}\right)_{0.94}\left(\mathrm{AsO}_{4}\right)_{0.12}\right]_{\Sigma 1.06}(\mathrm{OH})_{0.77}$

3. $\left(\mathrm{Cu}_{1.85} \mathrm{Zn}_{0.10} \mathrm{Fe}_{0.04}\right)_{\Sigma 1.99}\left[\left(\mathrm{PO}_{4}\right)_{0.79}\left(\mathrm{AsO}_{4}\right)_{0.20}\right]_{\Sigma 0.99}(\mathrm{OH})_{1.05}$

4. $\left(\mathrm{Cu}_{1.92} \mathrm{Zn}_{0.05}\right)_{\Sigma 1.97}\left[\left(\mathrm{PO}_{4}\right)_{0.67}\left(\mathrm{AsO}_{4}\right)_{0.36}\right]_{\Sigma 1.03}(\mathrm{OH})_{0.87}$

5. $\left(\mathrm{Cu}_{1.85} \mathrm{Zn}_{0.09}\right)_{\Sigma 1.94}\left[\left(\mathrm{PO}_{4}\right)_{0.57}\left(\mathrm{AsO}_{4}\right)_{0.55}\right]_{\Sigma 1.12}(\mathrm{OH})_{0.54}$

6. $\left(\mathrm{Cu}_{1.62} \mathrm{Zn}_{0.37}\right)_{\Sigma 1.99}\left[\left(\mathrm{PO}_{4}\right)_{0.62}\left(\mathrm{AsO}_{4}\right)_{0.40}\right]_{\Sigma 1.02}(\mathrm{OH})_{0.90}$

7. theoretical composition of libethenite $\mathrm{Cu}_{2}\left(\mathrm{PO}_{4}\right)(\mathrm{OH})$. 
0.40 apfu As and up to 0.37 apfu $\mathrm{Zn}$. The elevated $\mathrm{Zn}$ content is more common in olivenite, which suggest the existence of the olivenite $(\mathrm{Cu})$ - adamite $(\mathrm{Zn})$ series. The empirical formulas of the studied libethenite are given in Table 28.

A striking phenomenon is the occurrence of a probably primary libethenite, discovered in specimens collected in $1972-1973$ at the $4^{\text {th }}$ level of the Huber mine. Libethenite intergrowth with dark violet fluorite constitutes several cm long black-green crystalline aggregates. Libethenite crystals, 2 to $3 \mathrm{~mm}$ long, with smoth or corroded crystal faces (Fig. 38) occur at the surface of these aggregates. They are partly covered by crystalline intensive yellow green dickite. The libethenite crystals are grey-green, black-green to nearly black with weak green internal reflections. The fluorite-libethenite-dickite accumulations occurred in quartz gangue with abundant colourless rock crystals, up to $1 \mathrm{~cm}$ long, and translucent to white tabular crystals of fluorapatite, up to $8 \mathrm{~mm}$ long. This libethenite was identified by X-ray powder diffraction and characterized by quantitative chemical analysis. In contrast to supergene libethenite, this type of material is compositionally homogeneous, free of zoning visible in BSE images. $\mathrm{Cu}$ and $\mathrm{P}$ are the dominant elements (Table 29), whereas contents of As (to 0.06), $\mathrm{Zn}$ (to 0.04 ) and $\mathrm{Al}$ (to 0.01 apfu) are minor. Its chemical formula calculated on the basis of $5(\mathrm{O}, \mathrm{OH})$, is $\left(\mathrm{Cu}_{1.96} \mathrm{Zn}_{0.04} \mathrm{Al}_{0.01}\right)_{\Sigma 2.01}\left[\left(\mathrm{PO}_{4}\right)_{0.89}\left(\mathrm{AsO}_{4}\right)_{0.06}\right]_{\Sigma 1.95}(\mathrm{OH})_{1.21}$.
Table 29 Chemical composition of libethenite of a probable primary origin (in wt. \%)

\begin{tabular}{|l|rcr|}
\hline & mean*1 & range*1 & $* 2$ \\
\hline $\mathrm{CuO}$ & 64.01 & $62.03-65.70$ & 66.54 \\
$\mathrm{CaO}$ & 0.08 & $0.04-0.12$ & \\
$\mathrm{ZnO}$ & 1.34 & $1.14-1.60$ & \\
$\mathrm{FeO}$ & 0.08 & $0.02-0.11$ & \\
$\mathrm{Al} \mathrm{O}_{3}$ & 0.29 & $0.28-0.32$ & \\
$\mathrm{P}_{2} \mathrm{O}_{5}$ & 25.97 & $24.55-28.26$ & 29.69 \\
$\mathrm{As}_{2} \mathrm{O}_{5}$ & 2.67 & $2.45-2.81$ & \\
$\mathrm{H}_{2} \mathrm{O}^{*}$ & 4.55 & & 3.77 \\
total & 99.00 & & 100.00 \\
\hline
\end{tabular}

* $\mathrm{H}_{2} \mathrm{O}$ content calculated from the ideal formula $\mathrm{Cu}_{2}\left(\mathrm{PO}_{4}\right)(\mathrm{OH})$ and charge balance.

*1 mean and range for 6 spot analyses

$* 2$ theoretical composition of libethenite $\mathrm{Cu}_{2}\left(\mathrm{PO}_{4}\right)(\mathrm{OH})$.

\section{Malachite $\mathrm{Cu}_{2}\left(\mathrm{CO}_{3}\right)(\mathrm{OH})_{2}$}

The first descriptions of malachite at Horní Slavkov date to mid-19 ${ }^{\text {th }}$ century (Krejčí 1855; Glückselig 1862 and other authors). Korbel (1991) distinguished three types of malachite in the Huber open pit. The first type forms deep green crystalline coatings, consisting of tiny crystals, covering pharmacosiderite. Green clay-like aggregates with well-preserved radial structure represent the second type. The last type of malachite forms thin compact coatings on greisen, which are in turn covered by azurite. Korbel (1991) published a spectral analysis,

Fig. 38 Crystals of libethenite of a probable primary origin. Huber mine, Krásno; width of photo $3 \mathrm{~mm}$. Nicon SMZ1500 microphotography (J. \& E. Sejkora).

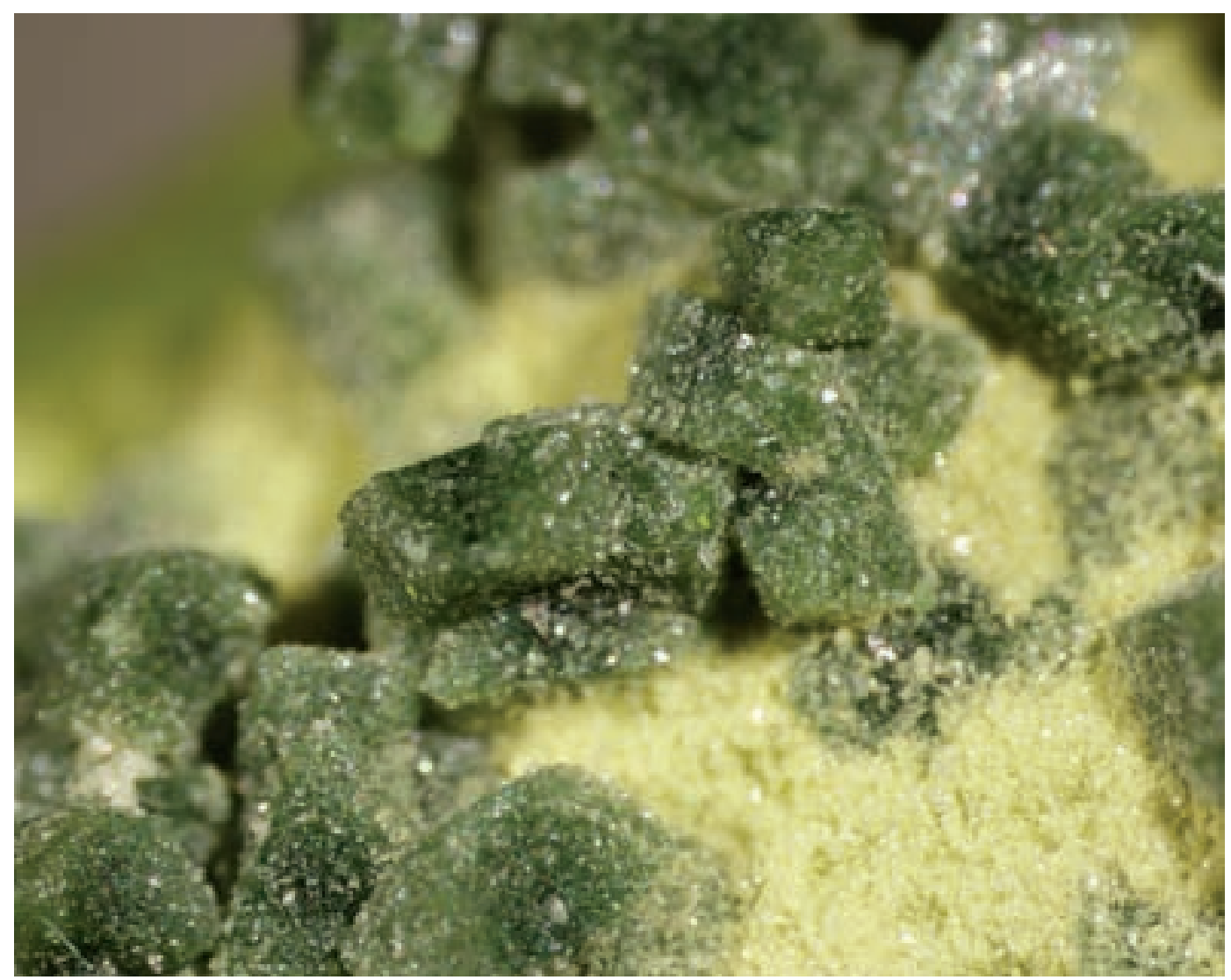


Table 30 Unit-cell parameters of malachite (for monoclinic space group $P 2 / a$ )

\begin{tabular}{|c|c|c|c|}
\hline & $\begin{array}{c}\text { Huber stock } \\
\text { Korbel (1991) }\end{array}$ & $\begin{array}{l}\text { Schnöd stock } \\
\text { this paper }\end{array}$ & Zigan et al. (1977) \\
\hline $\mathrm{a}[\AA]$ & $9.486(5)$ & $9.485(4)$ & 9.502 \\
\hline $\mathrm{b}[\AA]$ & 11.997(9) & $11.963(4)$ & 11.974 \\
\hline$c[\AA]$ & $3.241(1)$ & $3.241(1)$ & 3.24 \\
\hline$B\left[{ }^{\circ}\right]$ & $98.75(4)$ & $98.64(4)$ & 98.75 \\
\hline $\mathrm{V}\left[\AA^{3}\right]$ & 364.5 & 363.6 & 364.35 \\
\hline
\end{tabular}

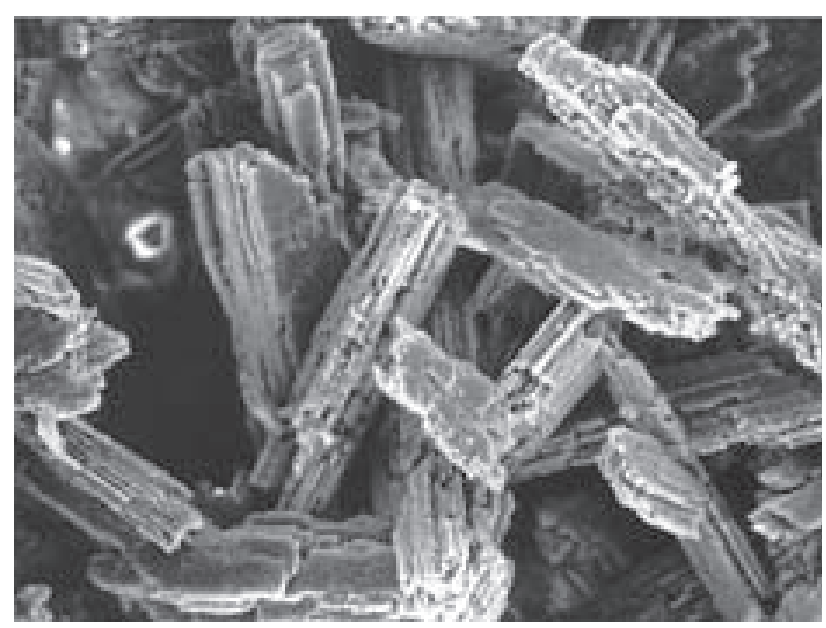

Fig. 39 Aggregate of corroded crystals of malachite; Huber open pit, Krásno; width of SE photo $400 \mu \mathrm{m}$; SEM Jeol JSM T-20 (Z. Mach).
X-ray powder diffraction data and refined unit-cell parameters for malachite (Table 30).

During the present study malachite has been found at several places of the district including the VII ${ }^{\text {th }}$ and VIII ${ }^{\text {th }}$ levels of the Schnöd stock, at the $4^{\text {th }}$ and $5^{\text {th }}$ level of the Huber stock, in the Huber open pit and at historical dumps around the open pit and behind the ventilation shaft No. 2. However, at all these places malachite is a relatively rare mineral. Malachite studied in detail formed bright green coatings of acicular crystals (Fig. 39), up to $5 \mathrm{~mm}$ long, in quartz gangue from the VII ${ }^{\text {th }}$ level of the Schnöd stock. It is associated with azurite, olivenite and pseudomalachite. This malachite specimen was identified by X-ray powder diffraction. The refined unit-cell parameters (Table 30) correspond well to the published data.

\section{Mansfieldite $\mathrm{AlAsO}_{4} \cdot 2 \mathrm{H}_{2} \mathrm{O}$}

Mansfieldite has been found as a rare mineral at several places in the Huber open pit. It occurs in small vugs of quartz gangue and greisen as white or greenish clusters of acicular crystals (Fig. 40) or radiating aggregates of very minute acicular crystals, up to $3 \mathrm{~mm}$ long (Figs 41, $42)$. In contrast to the substantially more common scorodite, the semi-spherical mansfieldite aggregates are light-coloured, nearly white to light green, with nearly smooth surface. Mansfieldite is associated with scorodite,

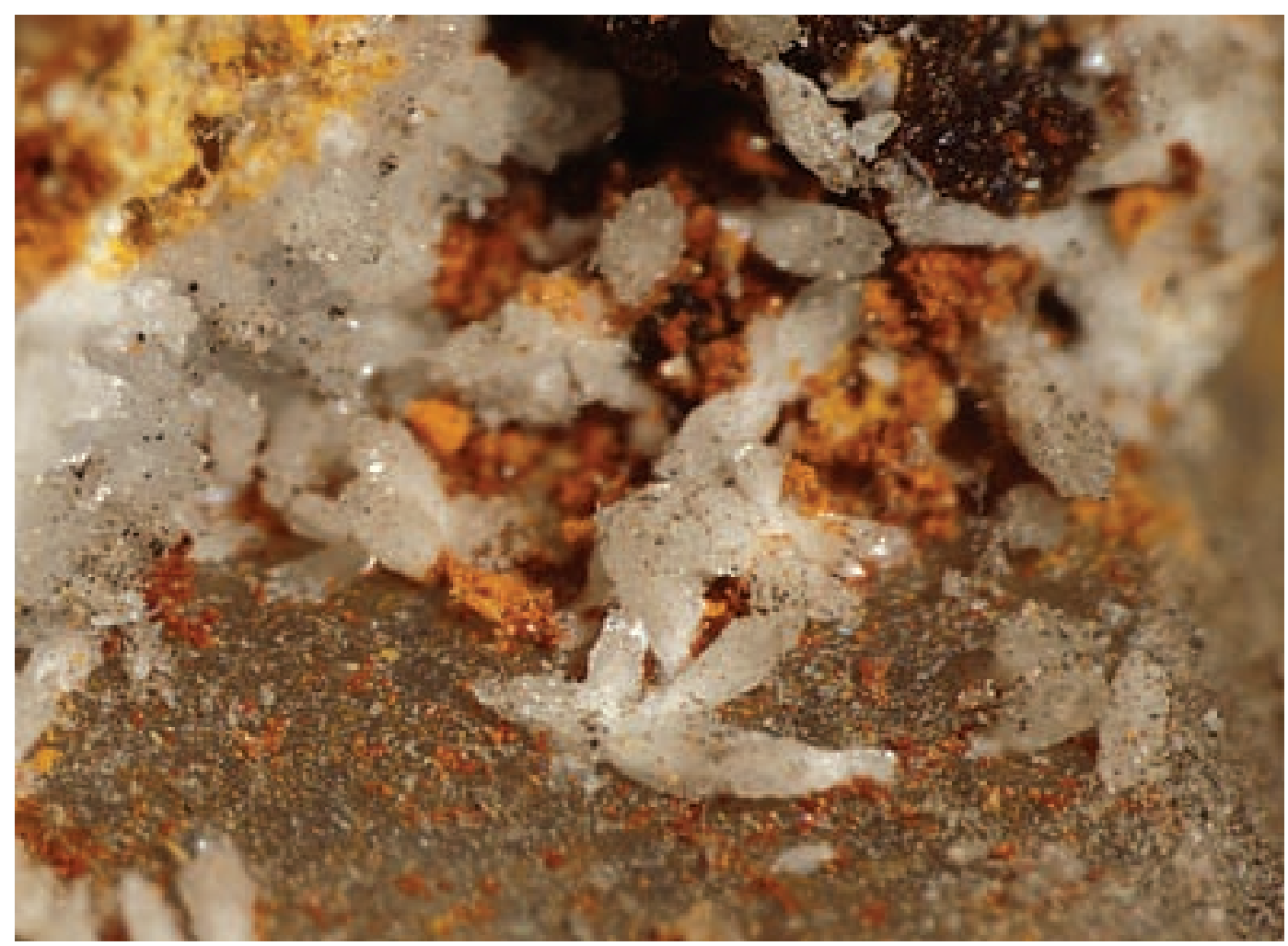

Fig. 40 Nearly white mansfieldite crystals deposited on brown "varlamoffite" aggregates in cavities of quartz gangue. Huber open pit, Krásno; width of photo $2 \mathrm{~mm}$. Nicon SMZ1500 microphotography (J. \& E. Sejkora). 


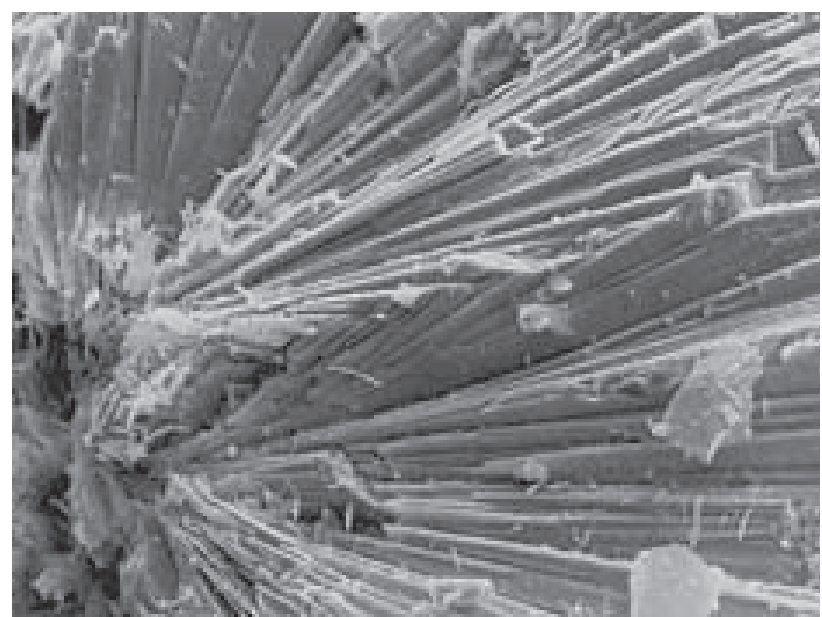

Fig. 41 Central part of a radiating aggregate of mansfieldite crystals. Huber open pit, Krásno; width of SE photo $200 \mu \mathrm{m}$. SEM Tesla 320 (A. Gabašová).

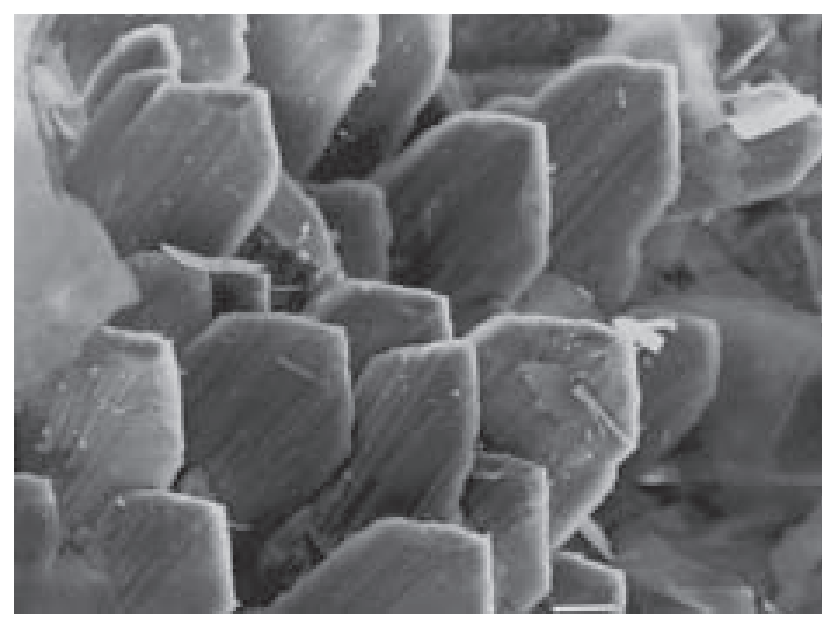

Fig. 42 Termination of mansfieldite crystals. Huber open pit, Krásno; width of SE photo $125 \mu \mathrm{m}$. Tesla 320 (A. Gabašová).

Table 31 Unit-cell parameters of mansfieldite (for orthorhombic space group $P c a b$ )

\begin{tabular}{|c|c|c|c|c|}
\hline & $\begin{array}{l}\text { mansfieldite } \\
\text { Huber stock } \\
\text { this paper }\end{array}$ & $\begin{array}{c}\text { mansfieldite } \\
\text { Oregon, USA } \\
\text { Anthony et al. }(2000)\end{array}$ & $\begin{array}{c}\text { skorodite* }^{*} \\
\text { - } \\
\text { Hawthorne (1976) }\end{array}$ & $\begin{array}{c}\text { variscite* }^{*} \\
- \\
\text { Kniep et al. (1977) }\end{array}$ \\
\hline $\mathrm{a}[\AA]$ & $10.096(3)$ & 10.08 & $10.278(2)$ & $9.822(3)$ \\
\hline $\mathrm{b}[\AA]$ & $9.823(5)$ & 9.76 & $9.996(2)$ & $9.630(3)$ \\
\hline$c[\AA]$ & $8.796(4)$ & 8.72 & $8.937(1)$ & $8.561(3)$ \\
\hline $\mathrm{V}\left[\AA^{3}\right]$ & 872.33 & 857.88 & 919.18 & 809.75 \\
\hline
\end{tabular}

* data are transformed to a comparable crystallographic setting

wolframite and cassiterite. A semiquantitative chemical study using ED equipment indicates that mansfieldite is strongly zoned in As-P and less in Al-Fe. Locally P predominates over As. The mineral was identified by X-ray powder diffraction. The refined unit-cell parameters (Table 31) are somewhat higher than those for mansfieldite, however, the problem could not be explained by substitutions by $\mathrm{As}$ and $\mathrm{Fe}$ (mansfieldite-scorodite, mansfieldite-variscite series) because they have opposite effects on the unit-cell parameters.

\section{Metatorbernite}

see torbernite - metatorbernite

\section{Mixite $\mathrm{BiCu}_{6}\left(\mathrm{AsO}_{4}\right)_{3}(\mathrm{OH})_{6} \cdot 3 \mathrm{H}_{2} \mathrm{O}$}

Mrázek (1981) described mixite from Horní Slavkov on the basis of X-ray powder data, spectral analysis and IR spectrum. Two types of occurrence are reported: fibrous to felt-like aggregates in cavities of quartz gangue and rare green-blue individual acicular crystals precipitated on crystalline crusts of olivenite. Korbel (1991) used some data published by Mrázek (1981) and newly presents optical properties $\left(\mathrm{N}_{\mathrm{o}}=1.745(3), \mathrm{N}_{\mathrm{e}}>1.780\right)$ and a slightly different X-ray powder pattern. Sejkora (1992) presented unit-cell parameters (Table 32), including comparison with other minerals of the mixite group.
During this study, mixite has been confirmed in quartz gangue from the marginal part of the Huber open pit. It forms green to light green compact and finely crystalline aggregates (Fig. 43) in association with cornwallite and minerals of the crandallite group. It was identified by $\mathrm{X}$-ray powder diffraction; the refined unit-cell parameters (Table 32) are in good agreement with the published data.

Table 32 Unit-cell parameters of mixite (for hexagonal space group $\left.P 6_{3} / m\right)$

\begin{tabular}{|l|ccc|}
\hline & $\begin{array}{c}\text { Huber stock } \\
\text { this paper }\end{array}$ & $\begin{array}{c}\text { Huber stock } \\
\text { Sejkora (1992) }\end{array}$ & Mereiter - Preisinger (1986) \\
\hline $\mathrm{a}[\AA]$ & $13.605(2)$ & $13.594(8)$ & $13.646(2)$ \\
$\mathrm{c}[\AA]$ & $5.909(1)$ & $5.920(5)$ & $5.920(1)$ \\
$\mathrm{V}\left[\AA^{3}\right]$ & 947.2 & $947 .(1)$ & 954.67 \\
\hline
\end{tabular}

\section{Mohrite $\left(\mathrm{NH}_{4}\right)_{2} \mathrm{Fe}^{2+}\left(\mathrm{SO}_{4}\right)_{2} \cdot 6 \mathrm{H}_{2} \mathrm{O}$}

Mohrite has been formed sub-recently on a weathered mixture of pyrite, chalcopyrite and covellite in the $\mathrm{Hu}-$ ber open pit. It constitutes thin glassy coatings of a light blue colour, up to several $\mathrm{cm}^{2}$ in size. Its crystallization was probably triggered by exposure of sulphide aggregates during mining. The mineral was identified by $\mathrm{X}$-ray powder diffraction. 


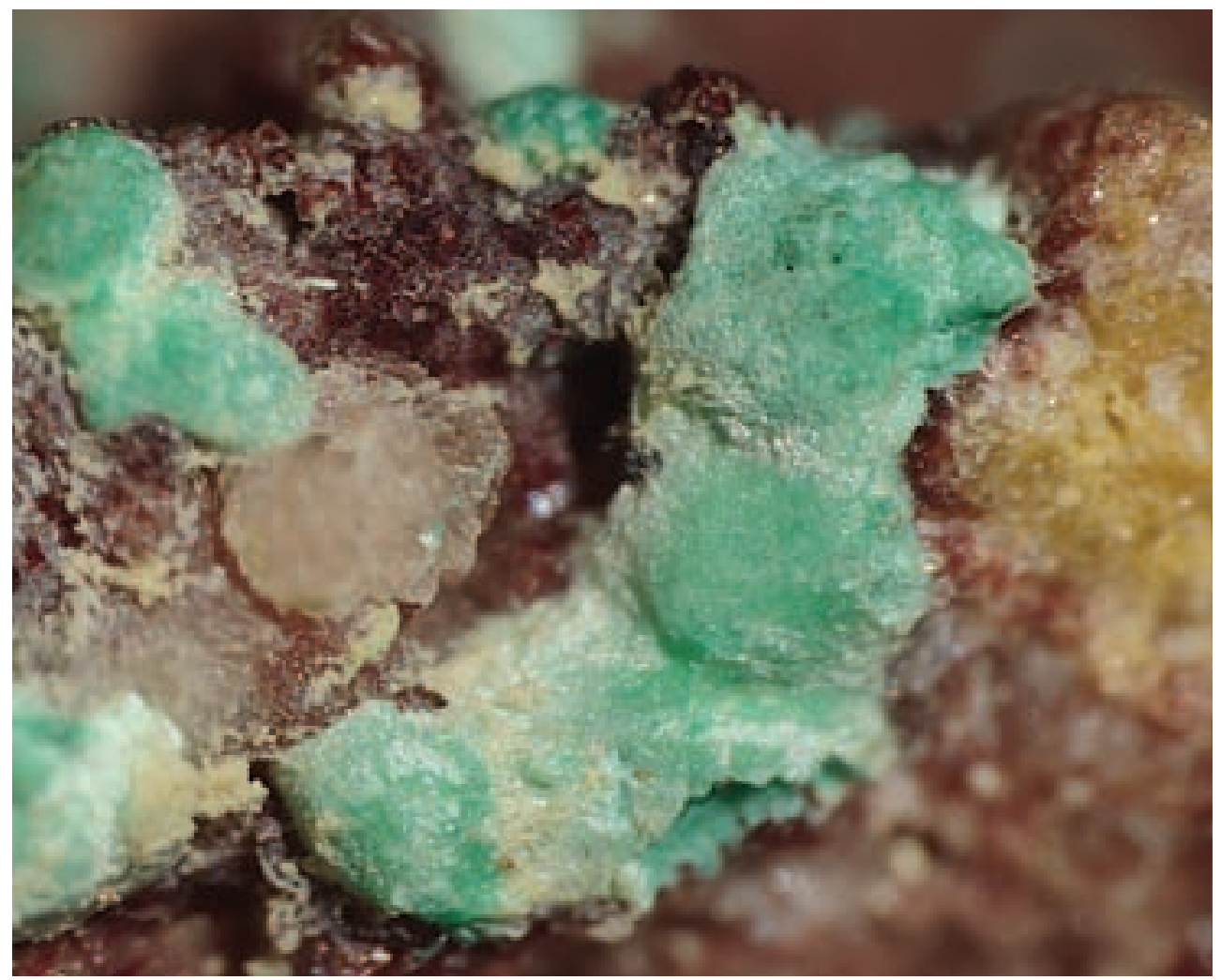

Fig. 43 Mixite aggregates on quartz gangue. Huber open pit; width of photo $2 \mathrm{~mm}$. Nicon SMZ1500 microphotography (J. \& E. Sejkora).

\section{Olivenite $\mathrm{Cu}_{2}\left(\mathrm{AsO}_{4}\right)(\mathrm{OH})$}

Breithaupt (1849) originally decribed olivenite in the association with quartz and feldspar but without any further details. Drozen (1967) described olivenite from the $4^{\text {th }}$ level of the Huber mine as short stalky, bunch-shaped and fan-shaped aggregates of pale green to yellow green colour in association with pseudomalachite in a greisen vug. Korbel (1991) presented a more detailed description of three morphological types of olivenite from the $\mathrm{Hu}-$ ber open pit. The first type is formed by black-green spherical aggregates with a radial structure which is associated with pseudomalachite; the next type occurs in a form of green scaly aggregates with mixite. The last type is represented by green clay-like aggregates with preserved radial structure, filling voids among quartz crystals. Korbel (1991) evidenced spectral analyses (indicating a high $\mathrm{Zn}$ content), X-ray powder diffraction data and refined unit-cell parameters (Table 33).

Newly obtained data show that olivenite is a widespread mineral not only in the Huber open pit but also

Ta b le 33 Unit-cell parameters of olivenite (for orthorhombic space group Pnnm)

\begin{tabular}{|l|cc|}
\hline & $\begin{array}{c}\text { Krásno } \\
\text { Korbel }(1991)^{*}\end{array}$ & Burns - Hawthorne (1995) \\
\hline $\mathrm{a}[\AA]$ & $8.560(6)$ & $8.5894(2)$ \\
$\mathrm{b}[\AA]$ & $8.191(12)$ & $8.2076(2)$ \\
$\mathrm{c}[\AA]$ & $5.904(9)$ & $5.9286(1)$ \\
$\mathrm{V}\left[\AA^{3}\right]$ & 414.0 & 417.96 \\
\hline
\end{tabular}

* transformation of unit-cell parameters $\mathrm{a}-\mathrm{b}$ in mining works in the Huber and Schnöd stocks. It usually forms crystalline aggregates composed of minute bipyramidal or acicular olive green crystals, up to $2 \mathrm{~mm}$ in size, (Figs 44-46). Specimens representing crusts of $\mathrm{mm}$-sized crystals deposited on crystals of white quartz are up to tens of $\mathrm{cm}^{2}$ in diameter (Fig. 47). The youngest (sub-recent) generation of olivenite forms light green coatings on fractures.

Olivenite has been confirmed by X-ray powder diffraction and semiquantitative chemical study. Also zoned aggregates of As-rich libethenite, including subordinate zones of P-rich olivenite were found (Fig. 48). Quantitative chemical analyses obtained for two selected specimens correspond to intermediate members of the olivenite-libethenite series, with about $0.40 a p f u$ P. The calculated empirical formulas are given in Table 34 .

Table 34 Chemical composition of olivenite (in wt. \%)

\begin{tabular}{|l|ccc|}
\hline & 1. & 2. & 3. \\
\hline $\mathrm{CuO}$ & 60.38 & 55.38 & 56.21 \\
$\mathrm{ZnO}$ & & 2.67 & \\
$\mathrm{P}_{2} \mathrm{O}_{5}$ & 11.02 & 11.92 & \\
$\mathrm{As}_{2} \mathrm{O}_{5}$ & 24.83 & 25.52 & 40.61 \\
$\mathrm{H}_{2} \mathrm{O}^{*}$ & 3.66 & 2.65 & 3.18 \\
total & 99.89 & 98.14 & 100.00 \\
\hline
\end{tabular}

* $\mathrm{H}_{2} \mathrm{O}$ content calculated on the basis of the ideal formula $\mathrm{Cu}_{2}\left(\mathrm{AsO}_{4}\right)(\mathrm{OH})$ and charge balance.

The following empirical formulas were calculated on the basis of $5(\mathrm{O}, \mathrm{OH})$

1. $\mathrm{Cu}_{2.01}\left[\left(\mathrm{AsO}_{4}\right)_{0.57}\left(\mathrm{PO}_{4}\right)_{0.41}\right]_{20.98}(\mathrm{OH})_{1.07}$

2. $\left(\mathrm{Cu}_{1.88}^{2.01} \mathrm{Zn}_{0.09}\right)_{\Sigma 1.97}\left[\left(\mathrm{AsO}_{4}\right)_{0.60}\left(\mathrm{PO}_{4}\right)_{0.42}\right]_{\Sigma 1.02}(\mathrm{OH})_{0.78}$

3. theoretical composition of olivenite $\mathrm{Cu}_{2}\left(\mathrm{AsO}_{4}\right)(\mathrm{OH})$. 
Fig. 44 Group of olivenite crystals showing irregular olive coloration. Huber open pit, Krásno; width of photo $5 \mathrm{~mm}$. Nicon SMZ1500 microphotography (J. \& E. Sejkora).

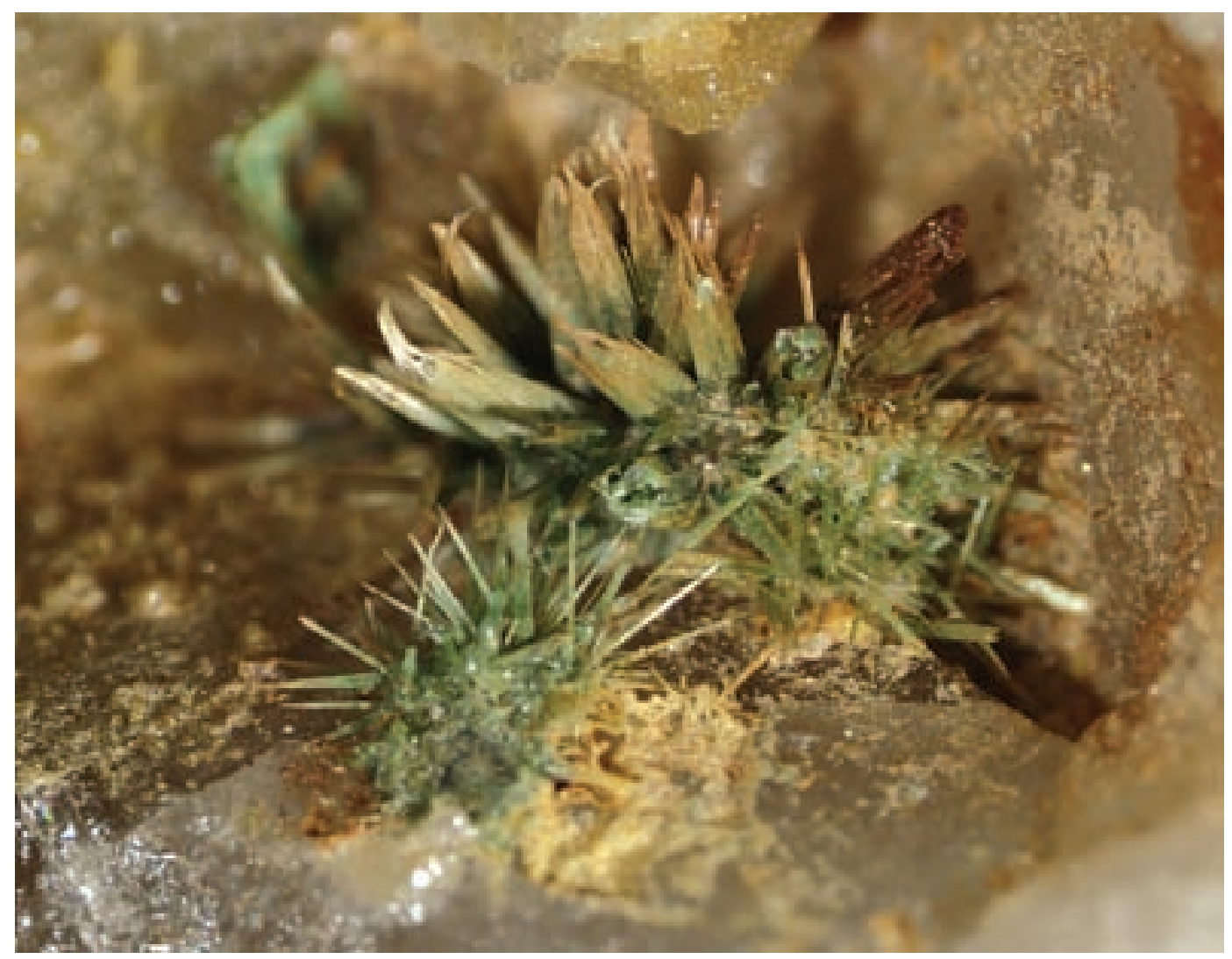

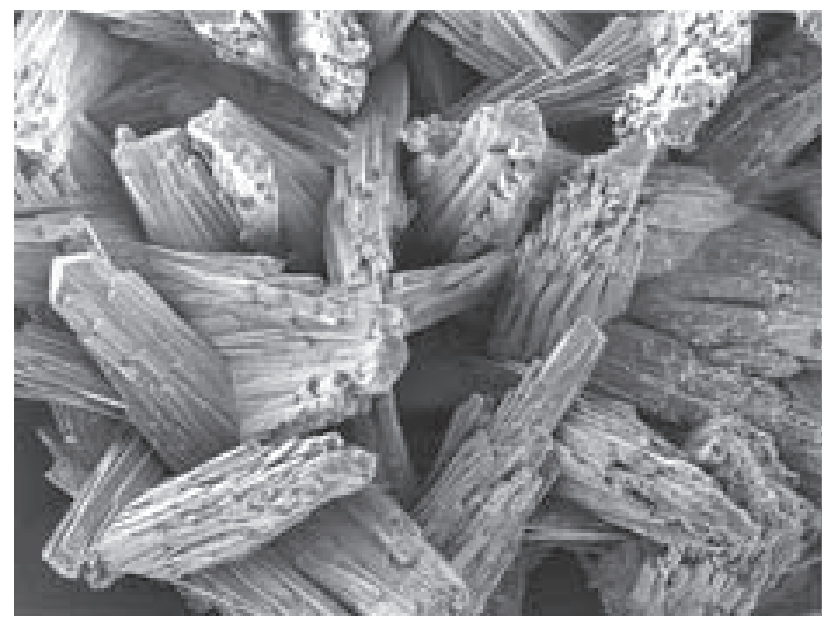

Fig. 45 Aggregate of long prismatic crystals of olivenite; Huber open pit, Krásno; width of SE photo $500 \mu \mathrm{m}$; SEM Tesla 320 (A. Gabašová).

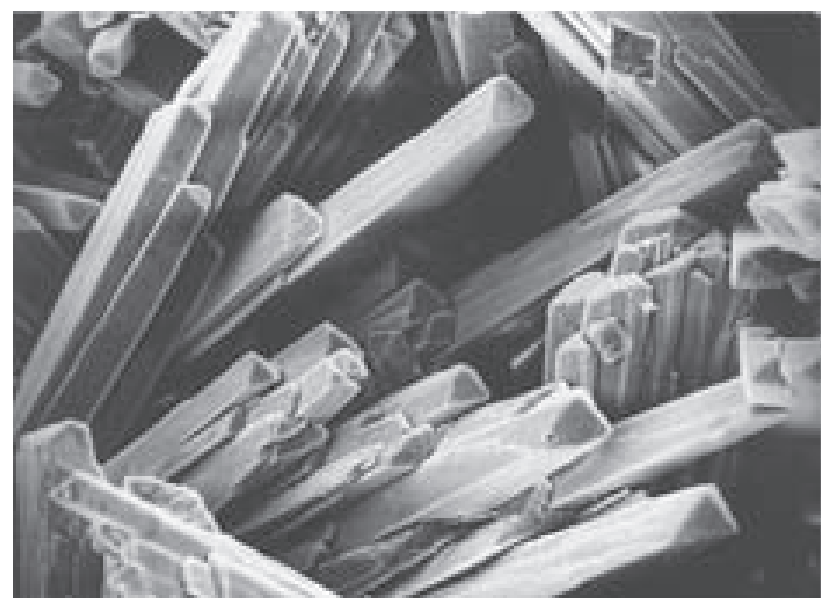

Fig. 46 Aggregates of parallel and randomly oriented olivenite crystals; Huber open pit, Krásno; Width of SE photo $500 \mu \mathrm{m}$. SEM Tesla 320 (A. Gabašová). 


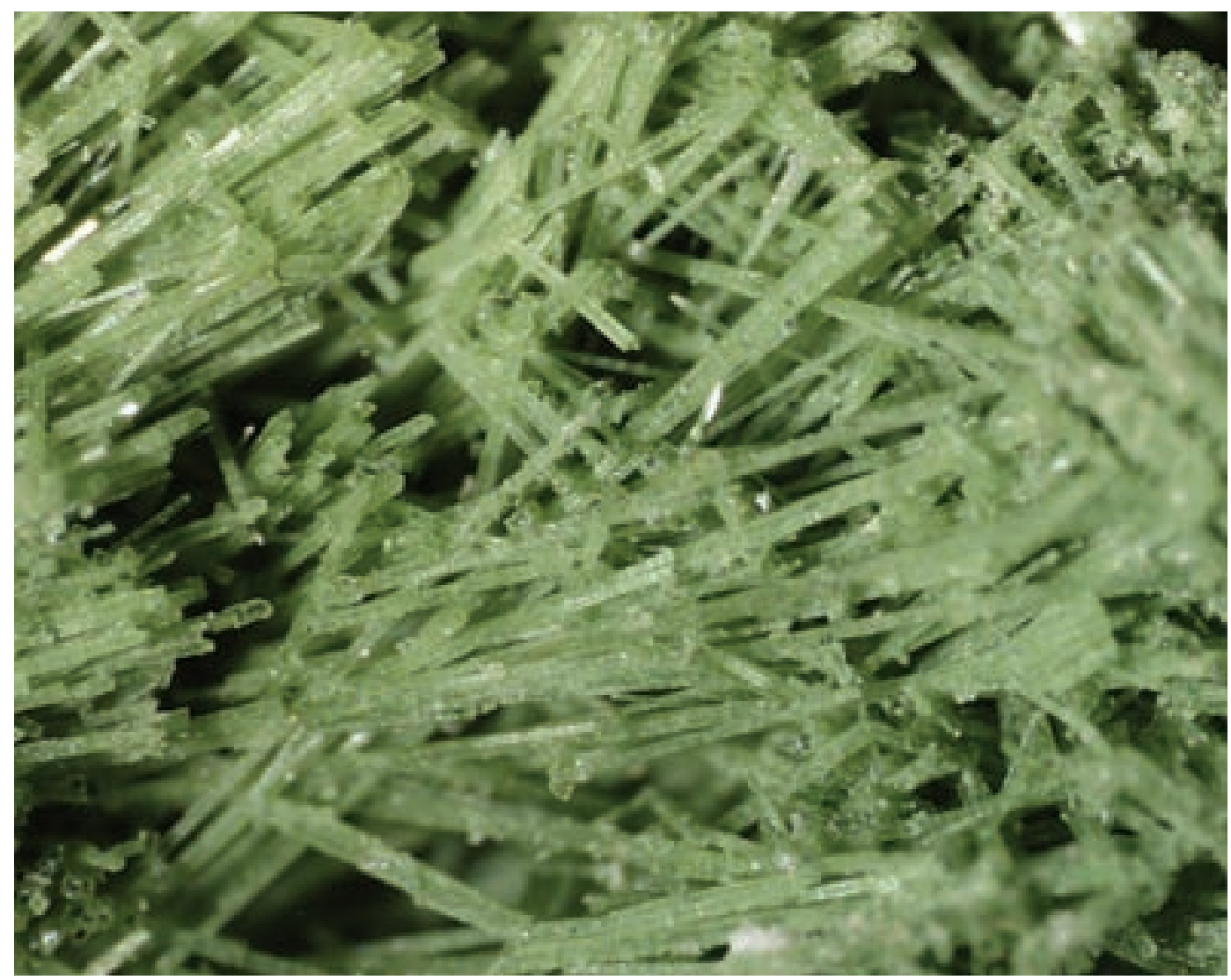

Fig. 47 Acicular olivenite crystals composing a rich coating on fracture of quartz gangue. Huber open pit, Krásno. Width of photo $3 \mathrm{~mm}$. Nicon SMZ1500 microphotography (J. \& E. Sejkora).

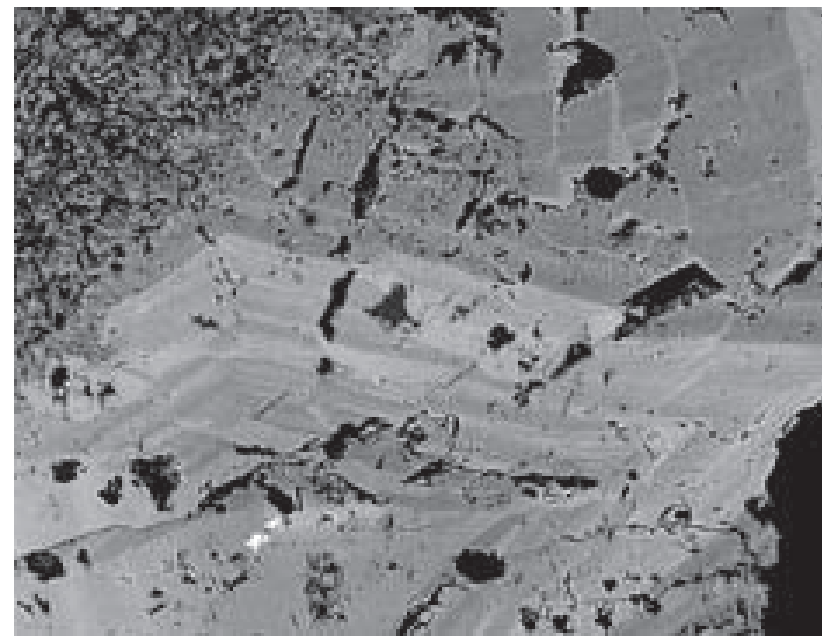

Fig. 48 Zoned aggregates of As-rich libethenite (darker) to P-rich olivenite (lighter zones); the very light inclusions are cassiterite. Width of BSE photo $400 \mu \mathrm{m}$. Cameca SX100 (J. Sejkora, R. Škoda).

\section{Petitjeanite $\mathrm{Bi}_{3} \mathrm{O}\left(\mathrm{PO}_{4}\right)(\mathrm{OH})$}

The mineral has been found as a dominant component (Fig. 49) of pseudomorphs after native Bi intergrown in coarse-grained quartz from the Huber open pit. Dark grey pseudomorphs with greasy lustre are $1-2 \mathrm{~mm}$ in size. The petitjeanite aggregates locally enclose fine relics of native $\mathrm{Bi}$ and their surface is coated by russellite.
Petitjeanite was identified by X-ray powder diffraction and its chemical composition (Table 35) is characterized by low contents of As up to 0.05-0.15 apfu. An extensive isomorphism $\mathrm{P}-\mathrm{As}-\mathrm{V}$ in the anion group of the preisingerite group minerals was already noted by Sejkora (1992). The empirical formula based on $10(\mathrm{O}, \mathrm{OH})$ is $\mathrm{Bi}_{3.04} \mathrm{O}_{1.00}\left[\left(\mathrm{PO}_{4}\right)_{1.72}\left(\mathrm{AsO}_{4}\right)_{0.09}\right]_{\Sigma 1.81}\left[(\mathrm{OH})_{1.81} \mathrm{~F}_{0.08}\right]_{\Sigma 1.89}$.

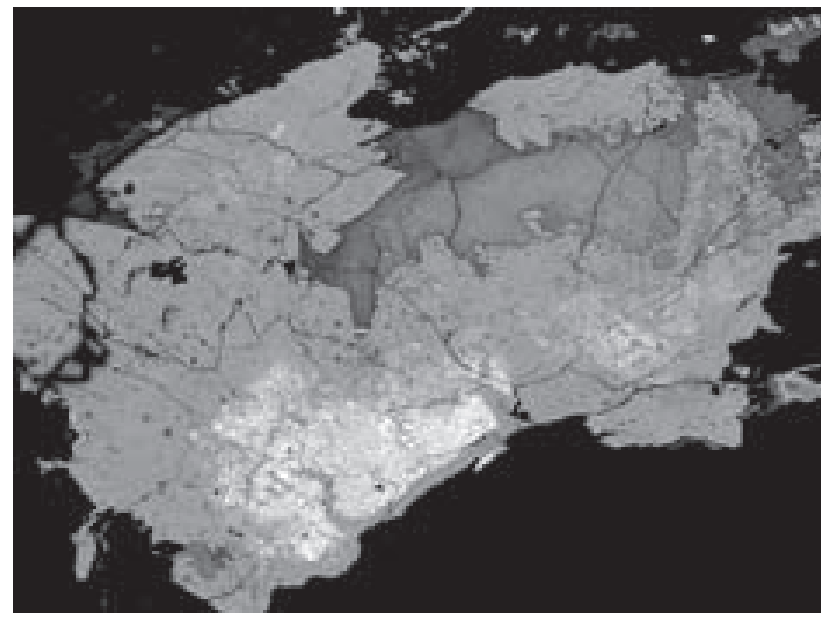

Fig. 49 Petitjeanite aggregate (grey), locally with abundant relics of native $\mathrm{Bi}$; the younger phase (dark grey) is russellite. Huber open pit, Krásno. Width of BSE photo $1 \mathrm{~mm}$. Cameca SX100 (J. Sejkora, R. Škoda). 
Table 35 Chemical composition of petitjeanite (in wt. \%)

\begin{tabular}{|l|ccc|}
\hline & mean*1 & range*1 & $* 2$ \\
\hline $\mathrm{Bi}_{2} \mathrm{O}_{3}$ & 82.18 & $81.81-82.54$ & 82.24 \\
$\mathrm{As}_{2} \mathrm{O}_{5}$ & 1.23 & $0.77-1.41$ & \\
$\mathrm{P}_{2} \mathrm{O}_{5}$ & 14.12 & $13.63-14.53$ & 16.70 \\
$\mathrm{~F}$ & 0.17 & $0.17-0.17$ & \\
$-\mathrm{O}=\mathrm{F}_{2}$ & 0.07 & & \\
$\mathrm{H}_{2} \mathrm{O}^{*}$ & 1.71 & & 1.06 \\
total & 99.33 & & 100.00 \\
\hline
\end{tabular}

* $\mathrm{H}_{2} \mathrm{O}$ content calculated from the ideal formula of petitjeanite $\mathrm{Bi}_{3} \mathrm{O}\left(\mathrm{PO}_{4}\right)_{2}(\mathrm{OH})$ and charge balance.

*1 mean and range of 3 spot analyses

*2 composition calculated from ideal formula $\mathrm{Bi}_{3} \mathrm{O}\left(\mathrm{PO}_{4}\right)_{2}(\mathrm{OH})$.

$$
\begin{aligned}
& \text { Pharmacosiderite } \mathrm{K}_{\mathrm{n}} \mathrm{Fe}^{3+}{ }_{4}\left(\mathrm{AsO}_{4}\right)_{3}(\mathrm{OH})_{4} \cdot 6-7 \mathrm{H}_{2} \mathrm{O} \\
& (\mathrm{n}=1-3)
\end{aligned}
$$

Hoffmann (1903) and Slavík (1903) published the first reports on pharmacosiderite. Drozen (1967) confirmed the occurrence of this mineral. Tacl - Blüml (1974) characterized three types of pharmacosiderite. It formed minute crystals of grass green colour, which protrude from finely crystalline coatings and clearly differ from larger crystals of scorodite. Pharmacosiderite also occurred in fine-grained greisen with small cavities carrying wolframite, chalcopyrite and other supergene minerals. Crust-like coatings of light green colour, very fine-grained and similar to clay material, come from the Huber open pit. A third type of pharmacosiderite forms lustrous crystalline coatings of emerald green colour, which are accompanied by partly decomposed wolframite. Korbel (1991) recognized five different types of pharmacosiderite. The first one is represented by green hexahedron crystals locally in combination with octahedron, up to $2 \mathrm{~mm}$ in size, in vugs of greisen. The second one includes aggregates of crystals $(<0.1 \mathrm{~mm})$ in cavities of quartz. The third type of pharmacosiderite forms green or brown crystalline crusts, composed of corroded crystals. The fourth type includes fine-grained to compact coatings with a warty surface. The last type is represented by light green material with a clay-like appearance. Korbel (1991) confirmed pharmacosiderite from Krásno by spectral analysis, X-ray powder diffraction data and refined unit-cell parameter (Table 36).

Mach (1979) designated barium-rich pharmacosiderite from Krásno as barium-pharmacosiderite. This mineral has been found in association with chalcosiderite as very minute crystals tending to crystalline crusts, yellow to yellow brown in colour, with a vitreous lustre. It cov-

Table 36 Unit-cell parameter of pharmacosiderite (for cubic space group $P 4-3 m$ )

\begin{tabular}{|l|ccc|}
\hline & $\begin{array}{c}\text { Huber stock } \\
\text { this paper }\end{array}$ & $\begin{array}{c}\text { Huber stock } \\
\text { Korbel }(1991)\end{array}$ & $\begin{array}{c}\text { - } \\
\text { Buerger } \text { et } \text { al. } .(1967)\end{array}$ \\
\hline $\mathrm{a}[\AA]$ & $7.945(1)$ & $7.965(1)$ & $7.9816(5)$ \\
$\mathrm{V}\left[\AA^{3}\right]$ & 501.51 & 505.31 & 508.48 \\
\hline
\end{tabular}

ers wolframite and cassiterite in a cavity in quartz. Crystal morphology is variable, with crystals usually similar to cube or rhombohedron (Figs 50, 51). Barium was determined by qualitative chemical analyses. Due to substitution of $\mathrm{K}$ by $\mathrm{Ba}$, $\mathrm{Na}$ etc. in the crystal structure of pharmacosiderite (Anthony et al. 2000), the members with dominating $\mathrm{Ba}$ are not considered as independent mineral species.

All the newly documented finds of pharmacosiderite come from the Huber open pit. Along with scorodite, pharmacosiderite is the most common product of decomposition of the primary sulfides. It frequently occurs in granular and earthy aggregates, particularly in proximity of arsenopyrite. Pharmacosiderite crystallized in typical striated cubes (Fig. 52), sometimes in combination with tetrahedral and rhombic dodecahedral crystal faces. The maximum size of crystals is $5 \mathrm{~mm}$. The mineral is usually green to deep green, less frequently yellow and brown.

Pharmacosiderite was identified by X-ray powder diffraction. Its refined unit-cell parameter (Table 36) is in

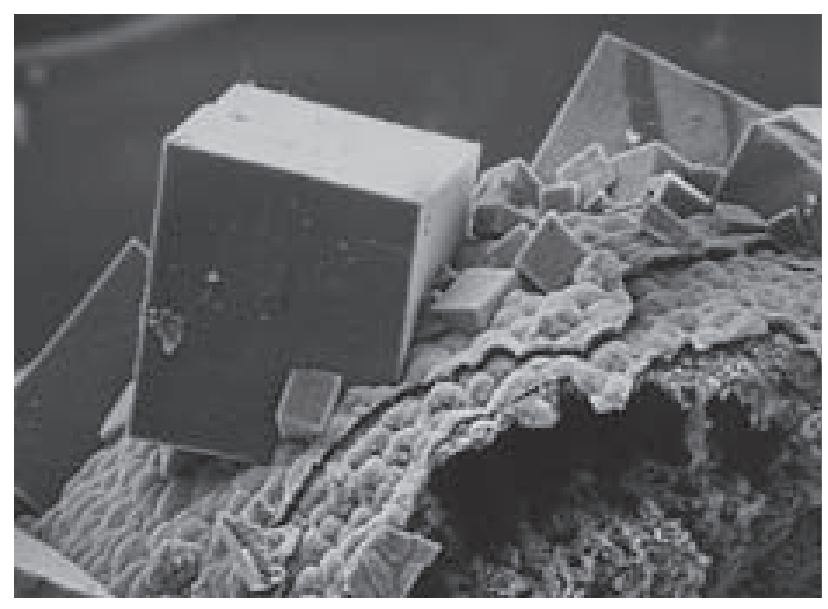

Fig. 50 Crystals of barium-rich pharmacosiderite. Huber open pit, Krásno. Width of SE photo $200 \mu \mathrm{m}$; SEM Tesla 320 (A. Gabašová).

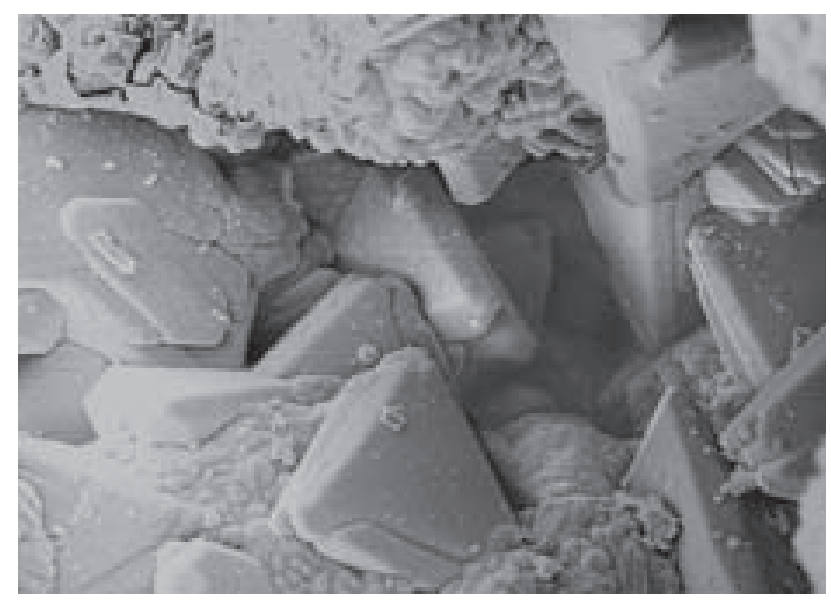

Fig. 51 Crystals of barium-rich pharmacosiderite. Huber open pit, Krásno. Width of SE photo $200 \mu \mathrm{m}$; SEM Tesla 320 (A. Gabašová). 
agreement with the published data. Quantitative chemical data (Table 37) were obtained for yellow, green and brown pharmacosiderite crystals deposited in cavities of quartz gangue (analyses 5-8) and for tiny crystals (analyses 1-4) associated with UNK3 (Sejkora et al. 2006a). The chemical formula for pharmacosiderite has previously been given as $\mathrm{KFe}_{4}\left(\mathrm{AsO}_{4}\right)_{3}(\mathrm{OH})_{4} \cdot 6-7 \mathrm{H}_{2} \mathrm{O}$. Studies by Mutter et al. (1984) and Peacor - Dunn (1985) indicated $\mathrm{K}$ (and $\mathrm{Na}$ ) in K-site near to 2 apfu. Pharmacosiderite from Krásno shows total K-site occupancy in the range of 1.15-2.15 (in association with UNK3) (Fig. 53) and 2.68-3.53 apfu (crystals from cavities in quartz). The variation in K-site occupancy depends on pharmacosiderite crystal structure, which consists of an open zeolitic framework $\left[\mathrm{Fe}_{4}(\mathrm{OH})_{4}\left(\mathrm{AsO}_{4}\right)_{3}\right]^{-}$with alkalis, alkaline

Table 37 Chemical composition of pharmacosiderite (wt. \%)

\begin{tabular}{|c|c|c|c|c|c|c|c|c|}
\hline & 1 & 2 & 3 & 4 & 5 & 6 & 7 & 8 \\
\hline $\mathrm{Na}_{2} \mathrm{O}$ & 0.07 & 1.37 & 0.36 & 0.39 & 1.10 & 0.37 & 0.51 & 0.53 \\
\hline $\mathrm{K}_{2} \mathrm{O}$ & 6.52 & 9.69 & 10.76 & 11.10 & 14.50 & 14.57 & 16.73 & 16.81 \\
\hline $\mathrm{CaO}$ & 0.00 & 0.00 & 0.14 & 0.01 & 0.05 & 0.00 & 0.09 & 0.06 \\
\hline $\mathrm{BaO}$ & 1.37 & 1.35 & 0.61 & 0.78 & 0.03 & 0.07 & 0.10 & 0.16 \\
\hline $\mathrm{SrO}$ & 0.00 & 0.00 & 0.06 & 0.00 & 0.16 & 0.10 & 0.09 & 0.15 \\
\hline $\mathrm{PbO}$ & 0.00 & 0.09 & 0.09 & 0.00 & 0.03 & 0.00 & 0.00 & 0.00 \\
\hline $\mathrm{CuO}$ & 0.27 & 0.00 & 0.40 & 0.00 & 0.06 & 0.22 & 0.03 & 0.14 \\
\hline $\mathrm{MnO}$ & 0.00 & 0.01 & 0.04 & 0.00 & 0.00 & 0.03 & 0.00 & 0.06 \\
\hline $\mathrm{ZnO}$ & 0.60 & 0.34 & 0.10 & 0.15 & 0.69 & 0.54 & 1.67 & 0.62 \\
\hline $\mathrm{Al}_{2} \mathrm{O}_{3}$ & 1.45 & 1.14 & 0.51 & 0.31 & 1.27 & 2.33 & 3.59 & 2.55 \\
\hline $\mathrm{Fe}_{2} \mathrm{O}_{3}$ & 37.45 & 35.56 & 37.96 & 37.98 & 32.77 & 32.67 & 30.92 & 30.71 \\
\hline $\mathrm{Sb}_{2} \mathrm{O}_{3}$ & 0.35 & 0.44 & 0.32 & 0.36 & 0.00 & 0.00 & 0.00 & 0.00 \\
\hline $\mathrm{SiO}_{2}$ & 0.01 & 0.00 & 0.01 & 0.05 & 0.00 & 0.00 & 0.00 & 0.00 \\
\hline $\mathrm{As}_{2} \mathrm{O}_{5}$ & 27.06 & 24.25 & 28.09 & 29.54 & 27.23 & 30.68 & 26.90 & 25.64 \\
\hline $\mathrm{P}_{2} \mathrm{O}_{5}$ & 10.92 & 10.52 & 8.57 & 8.12 & 5.48 & 4.05 & 5.82 & 6.79 \\
\hline $\mathrm{SO}_{3}$ & 0.00 & 0.11 & 0.14 & 0.13 & 0.09 & 0.00 & 0.00 & 0.03 \\
\hline $\mathrm{TiO}_{2}$ & 0.01 & 0.06 & 0.01 & 0.00 & 0.00 & 0.00 & 0.00 & 0.03 \\
\hline $\mathrm{H}_{2} \mathrm{O}^{*}$ & 19.69 & 19.43 & 19.90 & 19.82 & 18.86 & 19.28 & 19.95 & 19.21 \\
\hline total & 105.76 & 104.361 & 108.06 & 108.73 & 102.291 & 104.90 & 106.401 & 103.47 \\
\hline $\mathrm{Na}^{+}$ & 0.017 & 0.367 & 0.096 & 0.101 & 0.337 & 0.110 & $0 \quad 0.157$ & 0.160 \\
\hline $\mathrm{K}^{+}$ & 1.065 & 1.711 & 1.868 & 1.890 & 2.930 & 2.864 & $4 \quad 3.371$ & 3.354 \\
\hline $\mathrm{Ca}^{2+}$ & 0.000 & 0.000 & 0.020 & 0.001 & 0.008 & 0.000 & 0.014 & 0.009 \\
\hline $\mathrm{Ba}^{2+}$ & 0.069 & 0.073 & 0.032 & 0.041 & 0.002 & 0.004 & $4 \quad 0.006$ & 0.010 \\
\hline $\mathrm{Sr}^{2+}$ & 0.000 & 0.000 & 0.004 & 0.000 & 0.015 & 0.009 & 0.009 & 0.014 \\
\hline $\mathrm{Pb}^{2+}$ & 0.000 & 0.003 & 0.003 & 0.000 & 0.001 & 0.000 & 0.000 & 0.000 \\
\hline $\mathrm{Cu}^{2+}$ & 0.026 & 0.000 & 0.041 & 0.000 & 0.008 & 0.025 & 0.003 & 0.017 \\
\hline $\mathrm{Mn}^{2+}$ & 0.000 & 0.001 & 0.004 & 0.000 & 0.000 & 0.004 & 0.000 & 0.008 \\
\hline $\mathrm{Zn}^{2+}$ & 0.056 & 0.035 & 0.010 & 0.014 & 0.080 & 0.062 & 20.195 & 0.071 \\
\hline $\mathrm{Al}^{3+}$ & 0.218 & 0.186 & 0.082 & 0.049 & 0.237 & 0.424 & $4 \quad 0.668$ & 0.470 \\
\hline $\mathrm{Fe}^{3+}$ & 3.612 & 3.704 & 3.885 & 3.816 & 3.906 & 3.789 & 3.676 & 3.616 \\
\hline $\mathrm{Sb}^{3+}$ & 0.017 & 0.022 & 0.016 & 0.017 & 0.000 & 0.000 & 0.000 & 0.000 \\
\hline $\mathrm{Ti}^{4+}$ & 0.001 & 0.006 & 0.001 & 0.000 & 0.000 & 0.000 & 0.000 & 0.003 \\
\hline $\mathrm{Si}^{4+}$ & 0.002 & 0.001 & 0.001 & 0.007 & 0.000 & 0.000 & 0.000 & 0.000 \\
\hline $\mathrm{As}^{5+}$ & 1.814 & 1.755 & 1.998 & 2.063 & 2.255 & 2.472 & 2.222 & 2.097 \\
\hline $\mathrm{P}^{5+}$ & 1.185 & 1.233 & 0.987 & 0.918 & 0.734 & 0.528 & 0.778 & 0.899 \\
\hline $\mathrm{S}^{6+}$ & 0.000 & 0.012 & 0.014 & 0.013 & 0.010 & 0.000 & 0.000 & 0.004 \\
\hline $\mathrm{H}$ & 16.836 & 17.938 & 18.057 & 17.653 & 19.929 & 19.821 & 121.022 & 20.046 \\
\hline $\mathrm{OH}$ & 3.829 & 4.941 & 5.064 & 4.655 & 6.932 & 6.822 & 28.017 & 7.044 \\
\hline $\mathrm{H}_{2} \mathrm{O}$ & 6.503 & 6.498 & 6.496 & 6.499 & 6.499 & 6.500 & 6.503 & 6.501 \\
\hline
\end{tabular}

1-4 - representative spot analyses of various colour varieties of pharmacosiderite, 5-8 - representative spot analyses of pharmacosiderite associated with UNK3.

Coefficients of empirical formula were calculated on the basis of $(\mathrm{P}+\mathrm{As}+\mathrm{Si}+\mathrm{S})=3.00$;

* $\mathrm{H}_{2} \mathrm{O}$ content was calculated from the ideal formula with $\mathrm{H}_{2} \mathrm{O}=6.5$ and charge balance. earths and water molecules in the channels (Buerger et al. 1967). The water content varies considerably and the cations in the channels are considered to be exchangeable (Mutter et al. 1984). Potassium is the dominant element in K-site of all analysed pharmacosiderite samples from Krásno (Fig. 54); the contents of $\mathrm{Na}$ and $\mathrm{Ba}$ reach 0.37 and 0.07 apfu in maximum, respectively. In contrast to the majority of published pharmacosiderite analyses (Fig. 53), the studied samples contain increased Al in the range of 0.05-0.77 apfu. Pharmacosiderites with increased Al typically come from cavities in quartz gangue. Another characteristic feature of all studied samples from Krásno is a significant content of $\mathrm{P}$ (range of 0.53-1.23 apfu), as yet unreported in minerals of this group (Fig. 55). Empirical formulas for representative spot analyses of pharmacosiderite from Krásno are given in Table 37 .

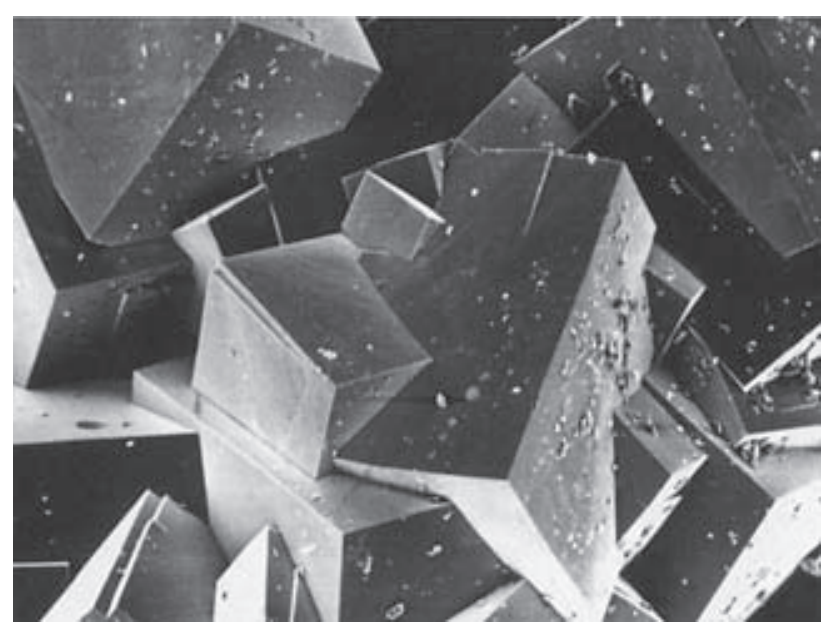

Fig. 52 Complex intergrowth of pharmacosiderite crystals. Huber open pit, Krásno. Width of SE photo $500 \mu \mathrm{m}$; SEM Jeol JSM T-20 (Z. Mach).
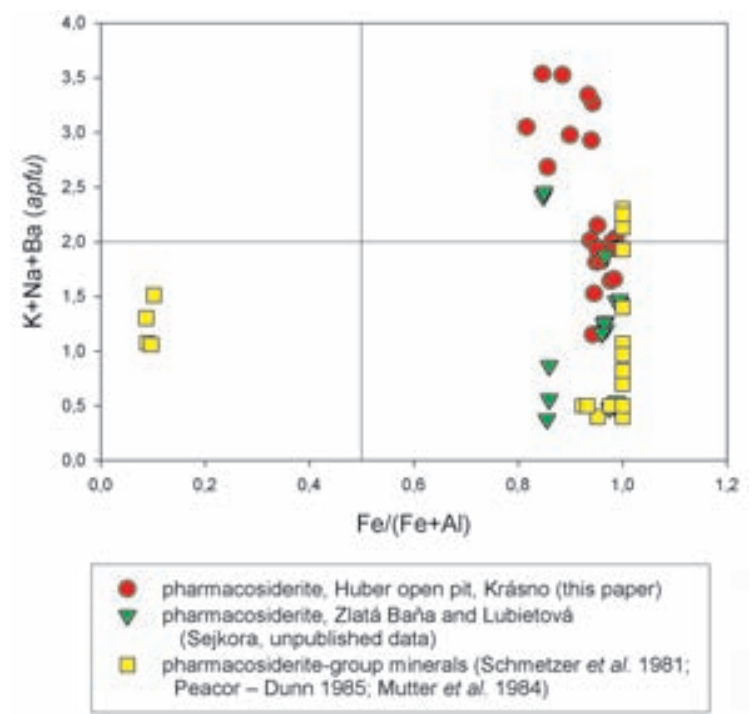

Fig. $53 \mathrm{Plot}$ of $\mathrm{Fe} /(\mathrm{Fe}+\mathrm{Al})$ vs. $\mathrm{K}+\mathrm{Na}+\mathrm{Ba}$ in $\mathrm{K}$-site in pharmacosiderite from Krásno. 


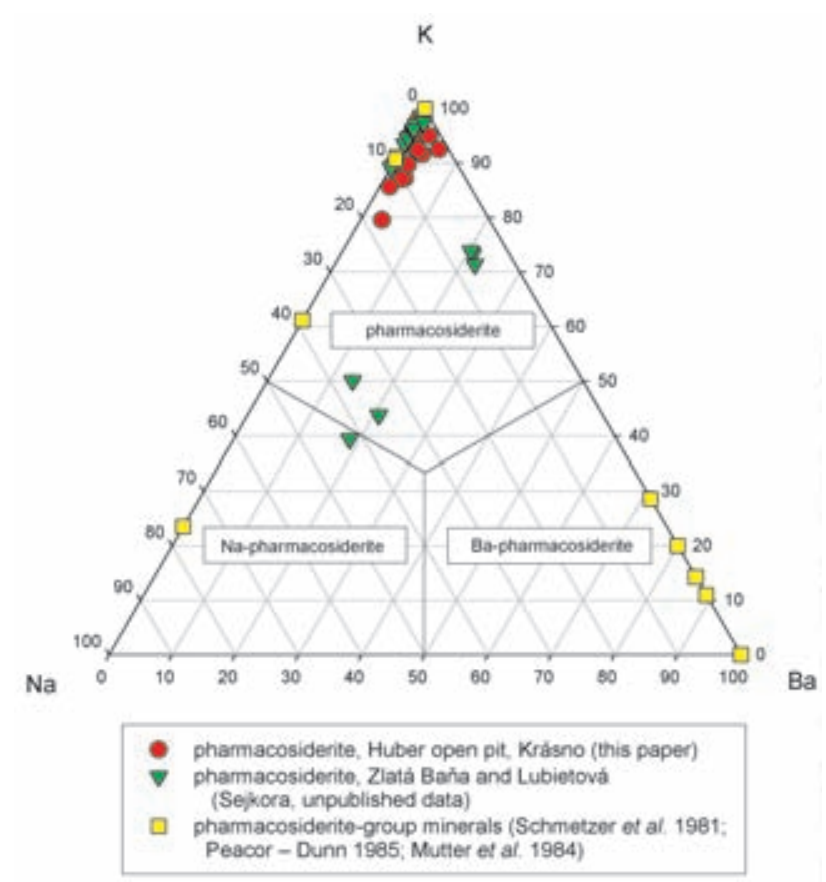

Fig. 54 Ternary plot of $\mathrm{K}-\mathrm{Na}-\mathrm{Ba}$ of K-site occupancy (atomic ratios) for pharmacosiderite from Krásno.
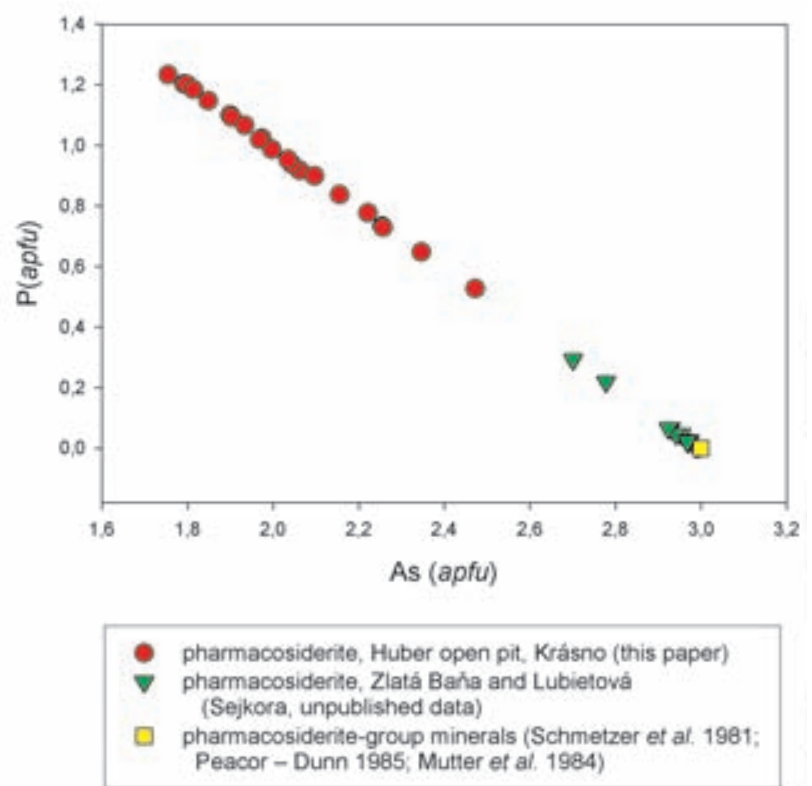

Fig. 55 Plot of As - P (apfu) in pharmacosiderite from Krásno.

\section{Posnjakite $\mathrm{Cu}_{4}\left(\mathrm{SO}_{4}\right)(\mathrm{OH})_{6} \cdot \mathrm{H}_{2} \mathrm{O}$}

Posnjakite has been observed relatively frequently on samples from the Huber open pit. It is associated with green to green-blue coatings of brochantite, malachite, chrysocolla and UNK2 (Sejkora et al. 2006a). This material occured on the surface of weathered veinlets and aggregates composed of primary cuprite, chalcocite and triplite. Posnjakite forms light blue crystalline crusts and rare sheaves of elongated crystals, up to $2 \mathrm{~mm}$ in size (Fig. 56). The mineral was identified by X-ray powder diffraction data. The refined unit-cell parameters (Table 38) are in good agreement with the data published for this species.

Ta b le 38 Unit-cell parameters of posnjakite (for monoclinic unit-cell $P a$ )

\begin{tabular}{|l|cc|}
\hline & $\begin{array}{c}\text { Huber stock } \\
\text { this paper }\end{array}$ & Mellini - Merlino (1967) \\
\hline $\mathrm{a}[\AA]$ & $10.4915(8)$ & $10.578(5)$ \\
$\mathrm{b}[\AA]$ & $6.338(3)$ & $6.345(3)$ \\
$\mathrm{c}[\AA]$ & $7.892(3)$ & $7.863(3)$ \\
$\beta\left[{ }^{\circ}\right]$ & $118.54(4)$ & $117.98(5)$ \\
$\mathrm{V}\left[\AA^{3}\right]$ & 461.0 & 466.06 \\
\hline
\end{tabular}

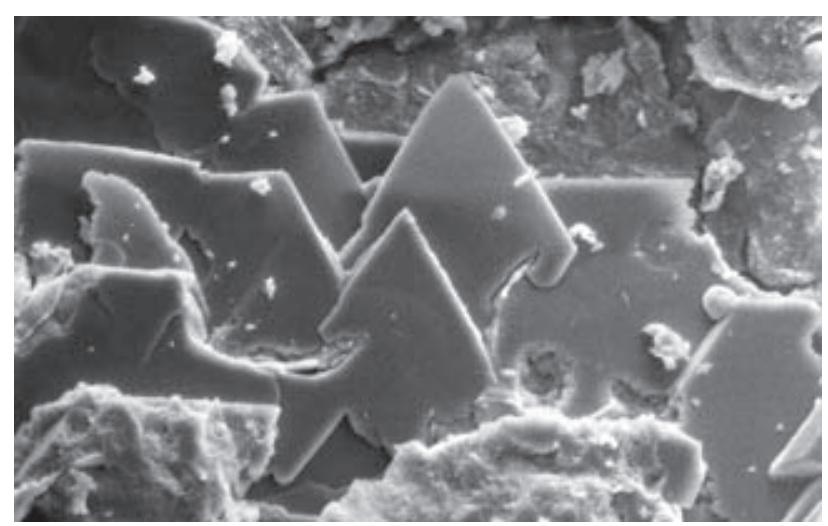

Fig. 56 Group of posnjakite crystals. The Huber open pit, Krásno; width of SE photo $100 \mu \mathrm{m}$; SEM Tesla 320 (A. Gabašová).

\section{Preisengerite $\mathrm{Bi}_{3} \mathrm{O}\left(\mathrm{AsO}_{4}\right)_{2}(\mathrm{OH})$}

Preisingerite is a typical component of dark grey pseudomorphs after native bismuth collected in the open pit and from the $4^{\text {th }}$ level of the Huber shaft in the Huber stock. These aggregates with greasy luster, 2-4 mm large, are intergrown in coarse-grained white quartz. Preisingerite is associated with relics of native $\mathrm{Bi}$, zavaritskite and bismutite. Younger yellow russellite coats the preisingerite pseudomorphs. Rare patchy preisingerite aggregates, up to $30 \mu \mathrm{m}$, are also intergrown with rooseveltite in scorodite crystalline aggregates (Fig. 57).

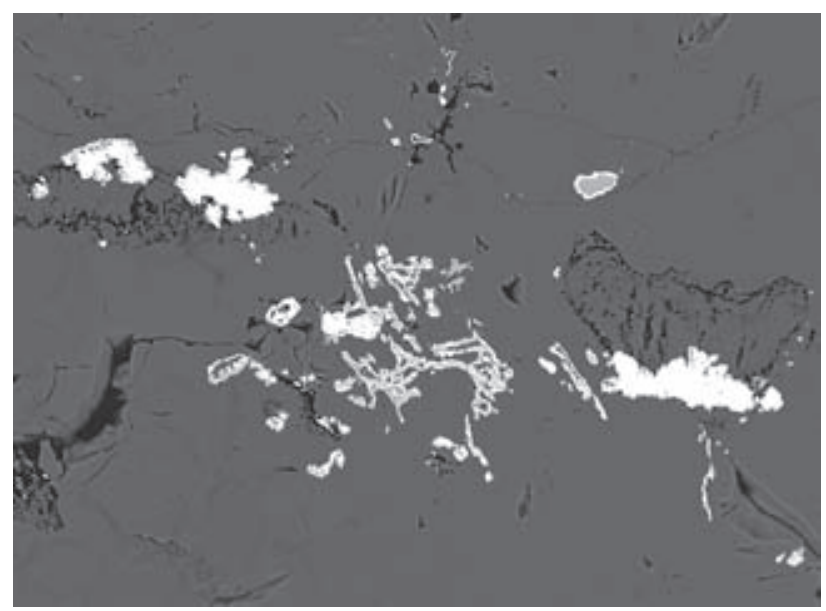

Fig. 57 Patchy preisingerite aggregates (white) with irregular veinlets of rooseveltite (grey), intergrown in scorodite (dark). Huber stock, Krásno; width of BSE photo $220 \mu \mathrm{m}$. Cameca SX100 (J. Sejkora, R. Škoda). 
Preisingerite was identified in mixture with zavaritskite and some other minerals by X-ray powder diffraction. The chemical composition of both types of preisingerite shows variable P content from 0.21 to $0.36 \mathrm{apfu}$, besides the dominant elements - Bi and As (Table 39). Such an extensive isomorphic substitutions in the anion group, involving As-P-V, has been described by Sejkora (1992). The empirical formula calculated on the basis of $10(\mathrm{O}, \mathrm{OH})$ is $\left(\mathrm{Bi}_{2.94} \mathrm{Fe}_{0.06}\right)_{\Sigma 3.00} \mathrm{O}_{1.00}\left[\left(\mathrm{AsO}_{4}\right)_{1.65}\left(\mathrm{PO}_{4}\right)_{0.27}\right]_{\Sigma 1.92}$ $\left[(\mathrm{OH})_{1.12} \mathrm{~F}_{0.10}\right]_{\Sigma 1.22}$.

Table 39 Chemical composition of preisingerite (in wt. \%)

\begin{tabular}{|l|rcr|}
\hline & mean*1 & range*1 & $* 2$ \\
\hline $\mathrm{Bi}_{2} \mathrm{O}_{3}$ & 74.53 & $73.49-75.37$ & 74.53 \\
$\mathrm{Fe}_{2} \mathrm{O}_{3}$ & 0.56 & $0.00-1.13$ & \\
$\mathrm{Al}_{2} \mathrm{O}_{3}$ & 0.02 & $0.00-0.06$ & \\
$\mathrm{As}_{2} \mathrm{O}_{5}$ & 20.71 & $19.44-22.31$ & 24.51 \\
$\mathrm{P}_{2} \mathrm{O}_{5}$ & 2.12 & $1.65-2.74$ & \\
$\mathrm{~F}$ & 0.22 & $0.19-0.26$ & \\
$-\mathrm{O}=\mathrm{F}_{2}$ & 0.09 & & 0.96 \\
$\mathrm{H}_{2} \mathrm{O}^{*}$ & 1.12 & & 100.00 \\
total & 99.19 & & \\
\hline
\end{tabular}

* $\mathrm{H}_{2} \mathrm{O}$ content calculated from the ideal formula of preisingerite $\mathrm{Bi}_{3} \mathrm{O}\left(\mathrm{AsO}_{4}\right)_{2}(\mathrm{OH})$ and charge balance.

* 1 mean and range of 4 spot analyses

$* 2$ composition calculated from ideal formula $\mathrm{Bi}_{3} \mathrm{O}\left(\mathrm{AsO}_{4}\right)_{2}(\mathrm{OH})$.

\section{Pseudomalachite $\mathrm{Cu}_{5}\left(\mathrm{PO}_{4}\right)_{2}(\mathrm{OH})_{4}$}

Drozen (1967) described pseudomalachite from Krásno as a powdery mineral of light blue green colour. Tacl Blüml (1974) confirmed the presence of pseudomalachite as well. Korbel (1991) described pseudomalachite in material from the Huber open pit as a relatively common mineral and distinguished three morphological types. The first type forms black green botryoidal crusts on olivenite and wolframite, the second one forms bluegreen crystalline aggregates in the quartz cavities, and is overgrowing pharmacosiderite. The last type of pseudomalachite occurs as blue green fine-grained to massive aggregates in association with younger azurite. Korbel (1991) also published spectral analysis, X-ray powder diffraction data and refined unit-cell parameters (Table 40).

Table 40 Unit-cell parameters of pseudomalachite (for monoclinic space group $P 2 / / c$ )

\begin{tabular}{|l|ccc|}
\hline & $\begin{array}{c}\text { pseudomalachite } \\
\text { Korbel } \\
(1991)^{*}\end{array}$ & $\begin{array}{c}\text { pseudomalachite } \\
\text { Shoemaker } \text { et al. } \\
(1997)\end{array}$ & $\begin{array}{c}\text { cornwallite } \\
\text { Arlt - Armbruster } \\
(1999)\end{array}$ \\
\hline $\mathrm{a}[\AA]$ & $4.482(6)$ & $4.4728(4)$ & $4.600(2)$ \\
$\mathrm{b}[\AA]$ & $5.758(3)$ & $5.7469(5)$ & $5.757(3)$ \\
$\mathrm{c}[\AA]$ & $17.09(1)$ & $17.302(3)$ & $17.380(6)$ \\
$\beta\left[{ }^{\circ}\right]$ & $90.94(4)$ & $91.043(7)$ & $91.87(3)$ \\
$\mathrm{V}\left[\AA^{3}\right]$ & 441.0 & 437.73 & 460.04 \\
\hline
\end{tabular}

* unit-cell parameters transformed to the standard setting in $\mathrm{P} 2 \mathrm{l} / \mathrm{c}$.
At present, pseudomalachite was identified by X-ray powder diffraction as minute crystals deposited directly on quartz from the VIII ${ }^{\text {th }}$ level of the Schnöd stock, in association with malachite, chrysocolla, apatite and triplite. It also occurs as small spheroidal aggregates on quartz crystals from the Huber open pit, quartz gangue around the open pit and the dump behind the ventilation shaft No. 2 (Fig. 58).

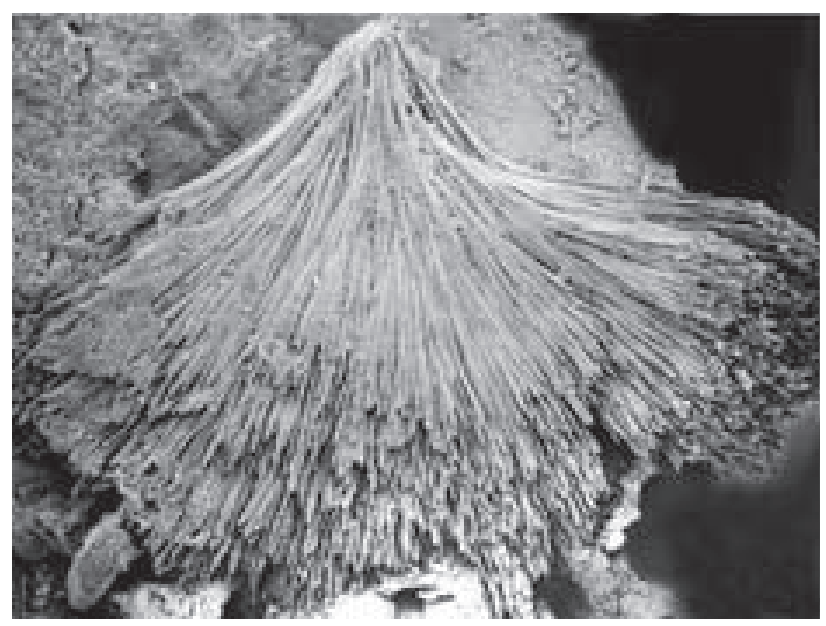

Fig. 58 Radiating aggregate of acicular crystals of pseudomalachite. Huber open pit, Krásno; width of SEM photo 2,5 mm; Jeol JSM T-20 (Z. Mach).

Remarkable specimens of pseudomalachite come from the Huber open pit. The mineral forms semi-spherical to spherical aggregates (Fig. 59), up to $0.2 \mathrm{~mm}$ in diameter, with surface showing very minute tabular crystals (Fig. 60). These aggregates at places coalesce to small coatings. The aggregates and coatings of As-rich pseudomalachite are deposited on irregular aggregates of inhomogeneous limonite (Fig. 61). The quantitative chemical study (Table 41) shows significant As contents up to 0.51-0.63apfu, besides low concentrations of Fe, $\mathrm{Ba}, \mathrm{Zn}, \mathrm{Al}$ and Si. The As-abundances indicate a partial isomorphism in the series pseudomalachite - cornwallite, proposed by Arlt - Armbruster (1999). The empi-

Table 41 Chemical composition of As-rich pseudomalachite (in wt. \%)

\begin{tabular}{|l|rcr|}
\hline & mean*1 & range*1 & $* 2$ \\
\hline $\mathrm{CuO}$ & 69.18 & $67.65-70.95$ & 69.09 \\
$\mathrm{FeO}$ & 0.57 & $0.38-0.77$ & \\
$\mathrm{BaO}$ & 0.17 & $0.00-0.33$ & \\
$\mathrm{ZnO}$ & 0.11 & $0.00-0.20$ & \\
$\mathrm{Al}_{2} \mathrm{O}_{3}$ & 0.45 & $0.35-0.59$ & \\
$\mathrm{SiO}_{2}$ & 0.21 & $0.20-0.24$ & \\
$\mathrm{As}_{2} \mathrm{O}_{5}$ & 11.57 & $10.37-12.47$ & \\
$\mathrm{P}_{2} \mathrm{O}_{5}$ & 15.86 & $14.74-16.31$ & 24.65 \\
$\mathrm{H}_{2} \mathrm{O}^{*}$ & 6.86 & & 6.26 \\
total & 104.98 & & 100.00 \\
\hline
\end{tabular}

* $\mathrm{H}_{2} \mathrm{O}$ content calculated from the ideal formula of pseudomalachite $\mathrm{Cu}_{5}\left(\mathrm{PO}_{4}\right)(\mathrm{OH})_{4}$ and charge balance.

$* 1$ mean and range of 6 spot analyses

*2 composition calculated from ideal formula $\mathrm{Cu}_{5}\left(\mathrm{PO}_{4}\right)(\mathrm{OH})_{4}$. 
Fig. 59 Semi-spherical to spherical aggregates of As-rich pseudomalachite deposited on $l i$ monite crust. Huber open pit, Krásno; width of photo $2 \mathrm{~mm}$; Nicon SMZ1500. Microphotography (J. \& E. Sejkora).

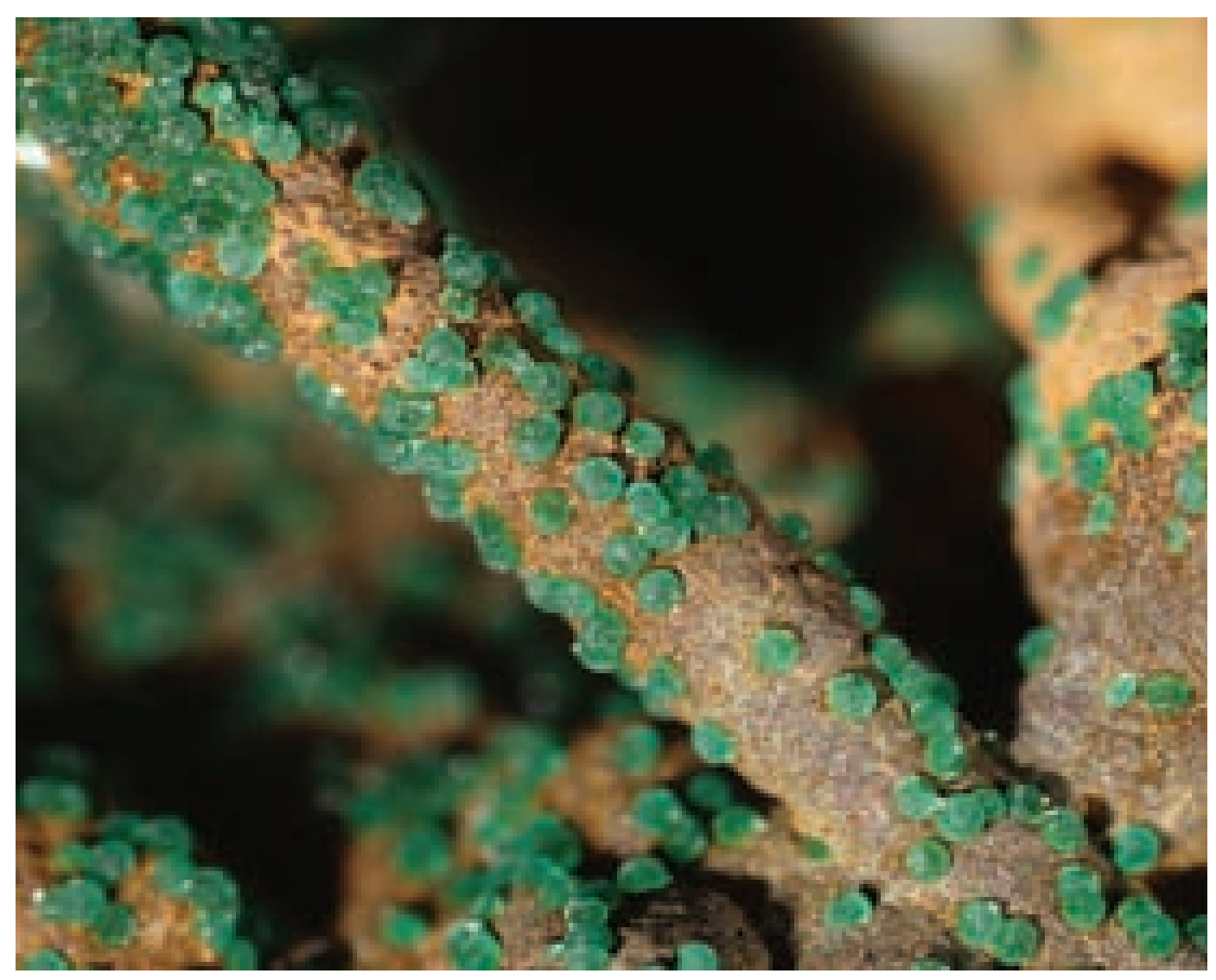

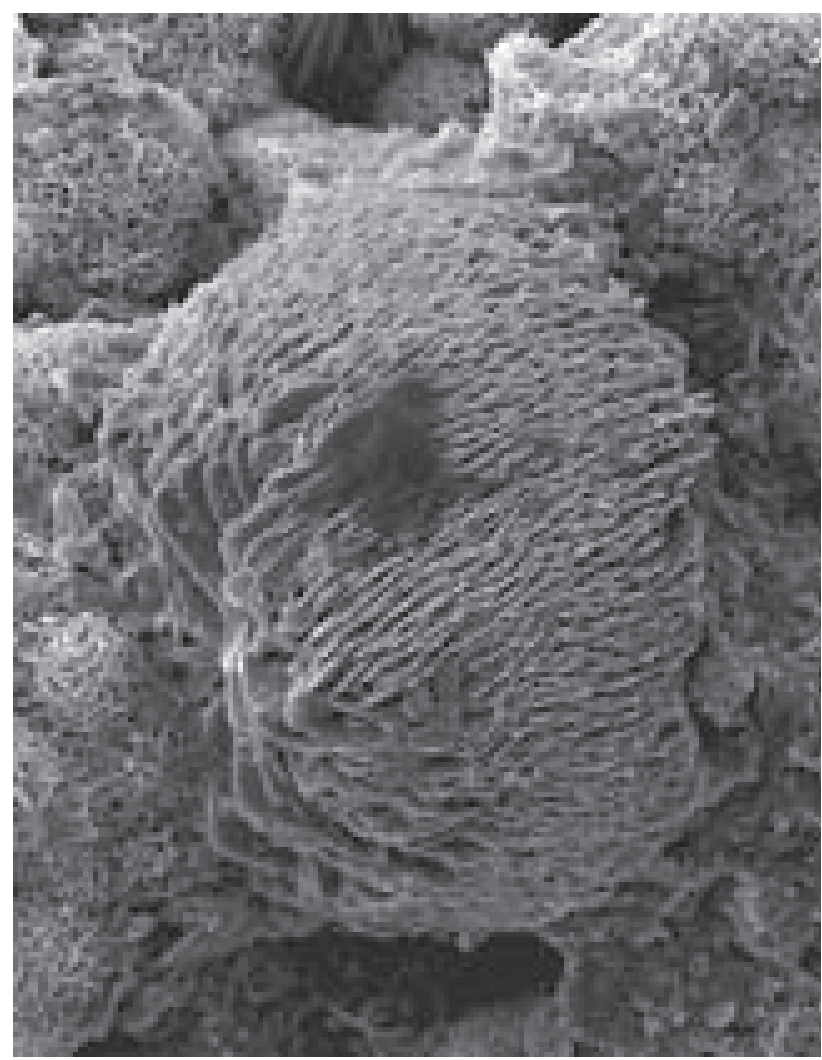

Fig. 60 Semi-spherical aggregates of thin tabular As-rich pseudomalachite crystals. Huber open pit, Krásno. Width of SE photo $160 \mu \mathrm{m}$. Jeol JSM-6380 (J. Sejkora and J. Plášil).

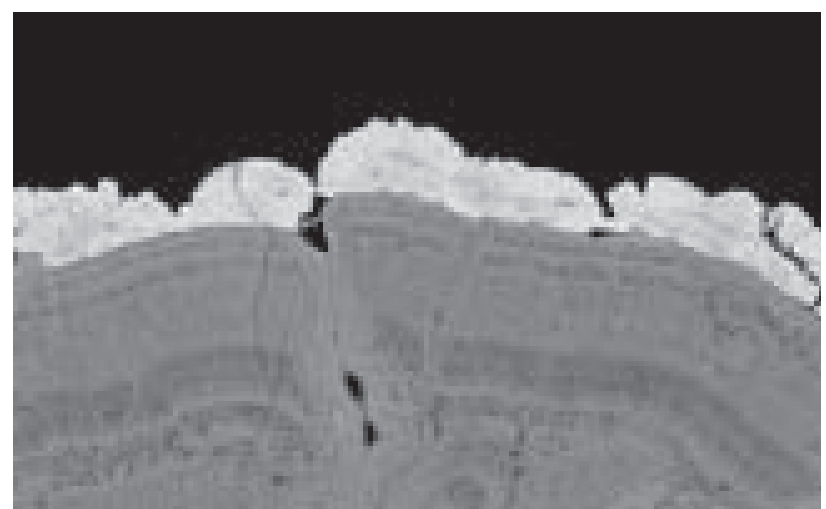

Fig. 61 Crystalline, in part semi-spherical aggregates of As-rich pseudomalachite (light) deposited on inhomogeneous limonite aggregate (dark). The lighter domains in pseudomalachite indicate a weak compositional zoning in $\mathrm{P}-\mathrm{A}$ and $\mathrm{Cu}-\mathrm{Fe}$, which is, however, nearly indistinct due to imperfetly polished surface of the specimen and graphite coating; Huber stock, Krásno. Width of BSE photo $800 \mu \mathrm{m}$. Cameca SX100 (J. Sejkora, R. Škoda). 
rical formula of As-rich pseudomalachite, based on $12(\mathrm{O}, \mathrm{OH})$ is $\left(\mathrm{Cu}_{4.95} \mathrm{Fe}_{0.05} \mathrm{Al}_{0.05}\right)_{\Sigma 5.05}\left[\left(\mathrm{PO}_{4}\right)_{1.27}\left(\mathrm{AsO}_{4}\right)_{0.57}\right.$ $\left.\left(\mathrm{SiO}_{4}\right)_{0.02}\right]_{\Sigma 1.86}(\mathrm{OH})_{4.55}$. The high totals of chemical analyses are probably due to sample dehydration by electron beam in vacuum.

\section{Rooseveltite $\mathrm{BiAsO}_{4}$}

A probable rooseveltite specimen consists of irregular veinlet-form aggregates up to $100 \mu \mathrm{m}$ long and only $1-$ $8 \mu \mathrm{m}$ wide (Fig. 62), intergrown in coarsely crystallized scorodite from the Huber stock. Preisingerite, goyazite and the unidentified phosphate of $\mathrm{U}$, Th and REE are the associated phases. Owing to the minimal proportion of the $\mathrm{BiAsO}_{4}$ aggregates it was not possible to test by

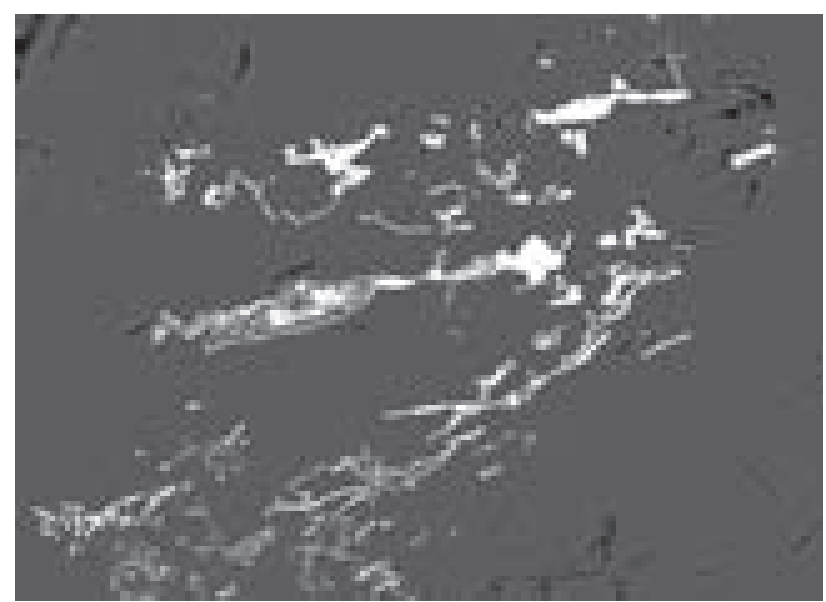

Fig. 62 Irregular veinlet-like aggregates of rooseveltite (light grey) in coarsely crystalline scorodite aggregate (dark grey), Huber stock, Krásno, width of BSE photo $200 \mu \mathrm{m}$. Cameca SX100 (J. Sejkora, R. Škoda).

X-ray examination whether the studied mineral belongs to tetragonal tetrarooseveltite or monoclinic rooseveltite. Since the monoclinic polymorph is more abundant in nature probably due to its larger stability field, it is suggested that the studied $\mathrm{BiAsO}_{4}$ mineral from Krásno is probably refers to rooseveltite.

Chemical analyses of rooseveltite (Table 42) show, in addition to major $\mathrm{Bi}$ and As contents, low concentrations

Table 42 Chemical composition of rooseveltite (in wt. \%)

\begin{tabular}{|l|rcc|}
\hline & mean*1 & range*1 & $* 2$ \\
\hline $\mathrm{Bi}_{2} \mathrm{O}_{3}$ & 66.59 & $64.40-68.27$ & 66.97 \\
$\mathrm{Fe}_{2} \mathrm{O}_{3}$ & 2.52 & $1.84-2.89$ & \\
$\mathrm{Al}_{2} \mathrm{O}_{3}$ & 0.12 & $0.06-0.21$ & \\
$\mathrm{As}_{2} \mathrm{O}_{5}$ & 29.78 & $26.92-30.83$ & 33.03 \\
$\mathrm{P}_{2} \mathrm{O}_{5}$ & 0.84 & $0.00-2.09$ & \\
$\mathrm{~F}$ & 0.29 & $0.00-0.45$ & \\
$-\mathrm{O}=\mathrm{F}_{2}$ & 0.12 & & \\
total & 100.01 & & 100.00 \\
\hline
\end{tabular}

* 1 mean and range of 6 spot analyses

$* 2$ composition calculated from ideal formula $\mathrm{Bi}\left(\mathrm{AsO}_{4}\right)$. of $\mathrm{Fe}(0.08$ to 0.13$), \mathrm{P}$ (to 0.08$)$ a $\mathrm{F}$ (to 0.10 apfu). Although it is difficult to exclude safely iron contribution from the enclosing scorodite, the Fe content does not vary with electron beam diameter $(0.7-5 \mu \mathrm{m})$ and the size of rooseveltite aggregates (3-8 $\mu \mathrm{m}$ in the analyzed sites). The empirical formula of rooseveltite based on $4 \mathrm{O}$ is $\left(\mathrm{Bi}_{0.98} \mathrm{Fe}_{0.11}\right)_{\Sigma 1.09}\left[\left(\mathrm{AsO}_{4}\right)_{0.89} \mathrm{~F}_{0.05}\left(\mathrm{PO}_{4}\right)_{0.04}\right]_{\Sigma 0.97}$.

\section{Russellite $\mathrm{Bi}_{2} \mathrm{WO}_{6}$}

Russellite is a typical minor component in quartz gangue and greisens which were enriched in Bi minerals. It forms light yellow to deep yellow powdery coatings in the proximity of aggregates of other Bi minerals. The surface of the coatings is irregular or botryoidal, with semi-spherical aggregates (Fig. 63), which are usually porous (Fig. 64). Russellite has also been identified as yellow powdery or plastic coatings in the proximity of altered grains of the native $\mathrm{Bi}$. Russellite is probably formed by

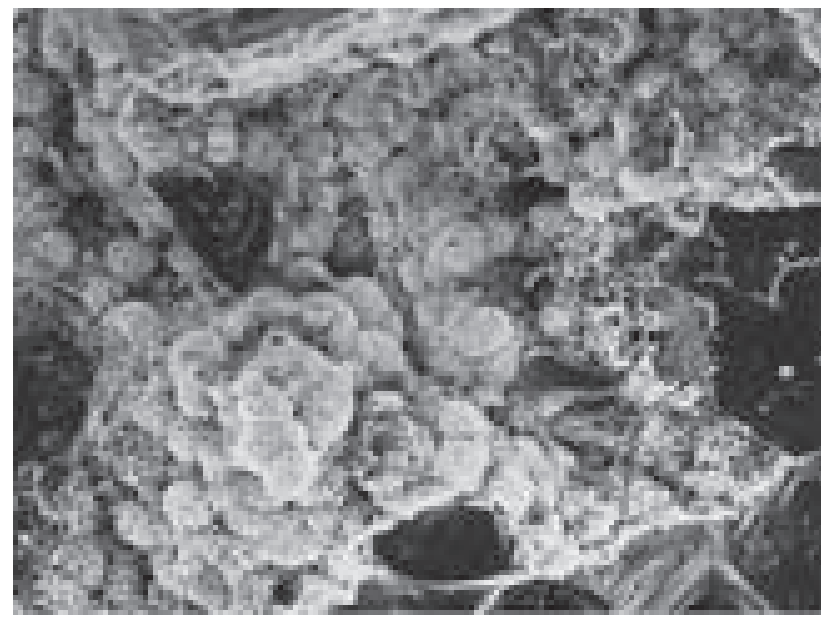

Fig. 63 Porous spheroidal aggregates of russellite. Huber open pit, Krásno. Width of SE photo $80 \mu \mathrm{m}$; SEM Jeol JSM T-20 (Z. Mach).

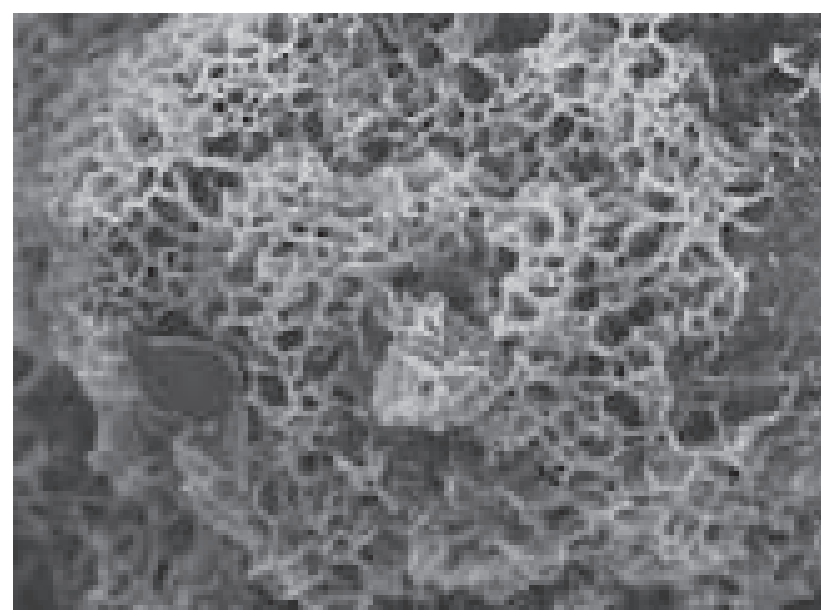

Fig. 64 Detail of porous russellite aggregate. Huber open pit, Krásno. Width of SE photo $20 \mu \mathrm{m}$; SEM Tesla 320 (A. Gabašová). 
sub-recent activity of tungstate ions. It is often associated with dickite and other clay minerals. The mineral has been found at the $4^{\text {th }}$ level of the Huber shaft and in the Huber open pit.

The X-ray powder patterns of russellite from Krásno correspond to the data published for russellite with tetragonal symetry (Hodge 1970). The individual diffraction maxima have high $F W H M$ values of halfwidths of diffractions and their absolute intensities are subdued. The study of synthesized analogous phase (Knight 1992, Rae et al. 1991) shows that russellite is orthorhombic with closely similar $a$ and $b$ parameters (near 5.43-5.45). In view of an imperfect crystal state of russellite from Krásno, closely positioned diffractions are not sufficiently individualized. Consequently, the unit-cell parameters were refined for tetragonal symmetry (Table 43).

Ta b le 43 Unit-cell parameters of russellite (for tetragonal space groups I-42d or $14_{1} /$ amd)

\begin{tabular}{|l|cccc|}
\hline & $\begin{array}{c}\text { Huber stock*1 } \\
\text { this paper }\end{array}$ & $\begin{array}{c}\text { Huber stock*2 } \\
\text { this paper }\end{array}$ & $\begin{array}{c}\text { Huber stock*2 } \\
\text { Sejkora (1992) }\end{array}$ & $\begin{array}{c}\text { Poona } \\
\text { Hodge (1970) }\end{array}$ \\
\hline $\mathrm{a}[\AA]$ & $5.440(3)$ & $5.430(2)$ & $5.433(2)$ & 5.48 \\
$\mathrm{c}[\AA]$ & $11.514(7)$ & $11.50(3)$ & $11.60(1)$ & 11.5 \\
$\mathrm{~V}\left[\AA^{3}\right]$ & 340.74 & 339.1 & 342.40 & 345.35 \\
\hline
\end{tabular}

$1 *$ open pit at Huber stock

$2 * 4^{\text {th }}$ level of the Huber mine

\section{Scorodite $\mathrm{Fe}^{3+} \mathrm{AsO}_{4} \cdot 2 \mathrm{H}_{2} \mathrm{O}$}

Scorodite, one of the most common supergene minerals in the near-surface parts of the Huber stock, is frequently mentioned in the old literature. Glückselig (1862), Klvaňa (1886) and Hoffmann (1903) described the occurrence. Slavík (1903), in addition to an extensive description, published detailed goniometric study of crystal morphology. Later, Drozen (1967), Tacl - Blüml (1974) and Korbel (1991) presented results of spectral analysis, X-ray powder diffraction data and refined unit-cell parameters.

Scorodite is a typical mineral of the upper parts of the Huber stock. It formed due to decomposition of primary arsenopyrite. Scorodite finds during the last decade point to highly variable modes of occurrence, including powdery coatings and fill of vugs with arsenopyrite relics and also perfectly formed crystals with a large number of crystal faces and a wide range of colours (Figs 65-68). Beran (1999) described several morphological types of scorodite: - well-formed crystals of a sky-blue to blue green colour, rarely more than $5 \mathrm{~mm}$ in size, in cavities of quartz gangue, often in proximity of sulfides. There are typically only a few crystals in a single cavity,

- transparent green crystals with morphology somewhat similar to that of topaz. The colouration is uneven. It occured in small drusy cavities of grey quartz or greisen, in association with wolframite, limonite and sulfides,

Fig. 65 Prismatic crystal of scorodite. Krásno. Width of photo $2.2 \mathrm{~mm}$. Nicon SMZ1500 microphotography (J. \& E. Sejkora).

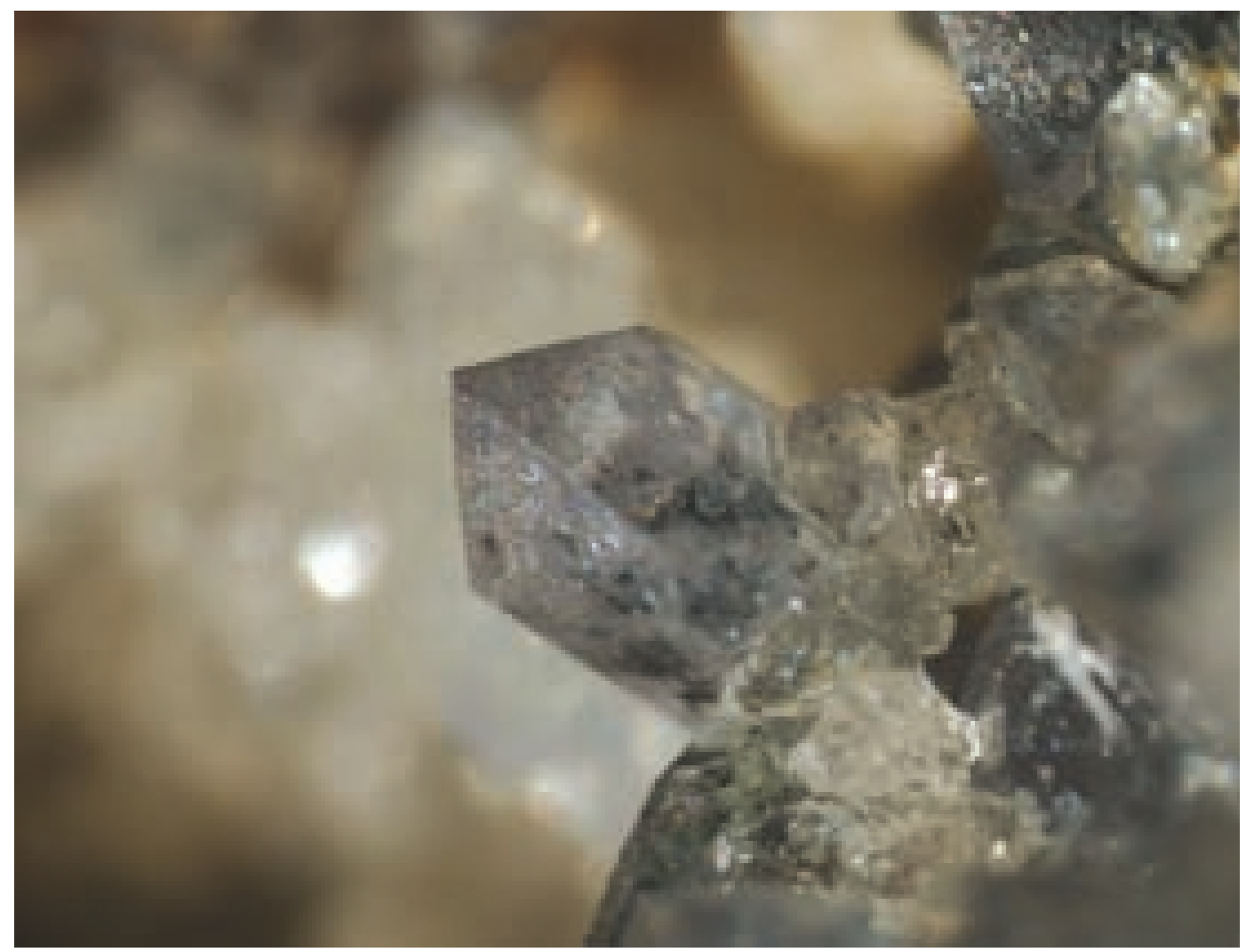




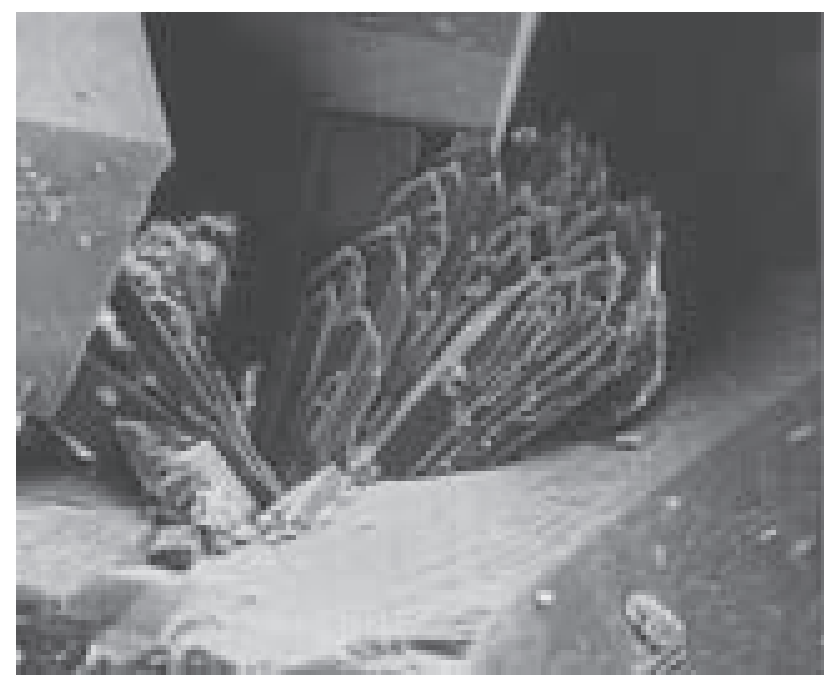

Fig. 66 A group of scorodite prismatic crystals deposited on pharmacosiderite crystals. Huber open pit, Krásno. Width of SE photo $0.6 \mathrm{~mm}$; SEM Jeol JSM T-20 (Z. Mach).

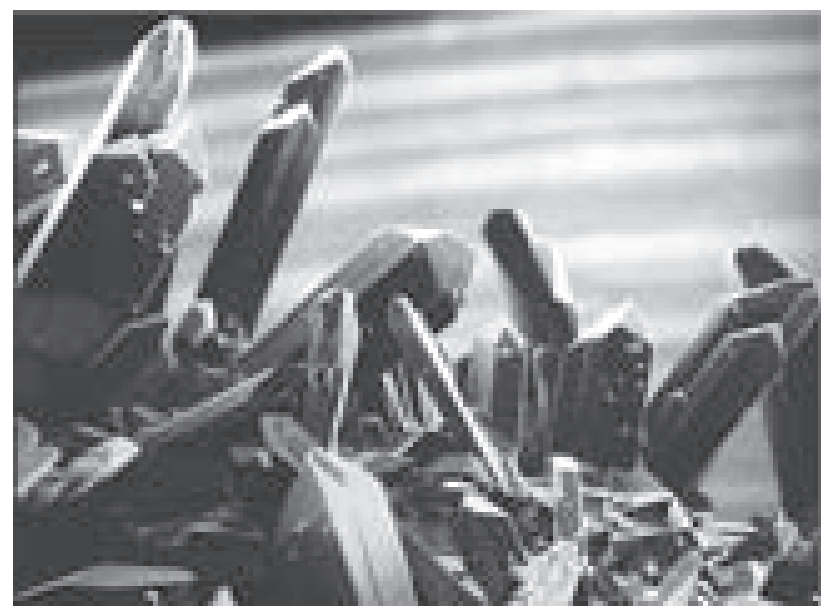

Fig. 67 A group of scorodite prismatic crystals. Huber open pit, Krásno. Width of SE photo $1.1 \mathrm{~mm}$; SEM Jeol JSM T-20 (Z. Mach).

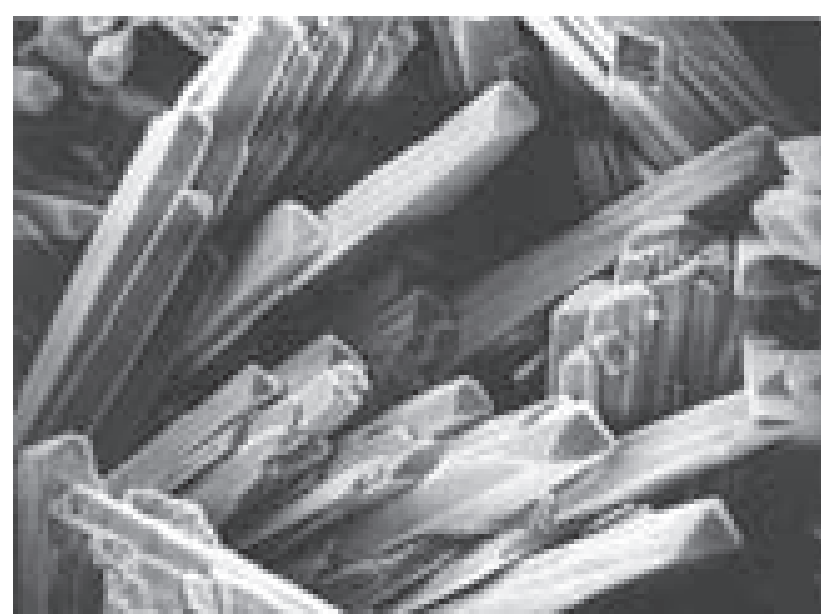

Fig 68 A group of scorodite prismatic crystals. Huber open pit, Krásno. Width of SE photo $250 \mu \mathrm{m}$; SEM Jeol JSM T-20 (Z. Mach).
- flat crystals of green or blue green colour, with a vitreous lustre, tend to form radiating flat aggregates on fractures of quartz gangue or greisen. It is typically associated with wolframite and cassiterite,

- non-transparent orthorhombic crystals, in places grouped in radiating or spheroidal aggregates with vitreous or greasy lustre; the aggregates occur in vugs in quartz gangue and may fill completely the space,

- green or green grey non-transparent aggregates with a greasy lustre, very fine-grained aggregates coating quartz crystals or cavities in greisen,

- $\quad$ spheroidal or grape-like aggregates of a light green or green grey colour, on arsenopyrite or other sulfides; the aggregates appear amorphous and have a variable lustre,

- green, poorly defined, amorphous-like aggregates similar to clay minerals.

The various scorodite types were identified by X-ray powder diffraction. The refined unit-cell parameters (Table 44) are in good agreement with the published data.

Tab le 44 Unit-cell parameters of scorodite (for orthorhombic space group $\mathrm{Pbca}$ )

\begin{tabular}{|c|c|c|c|}
\hline & $\begin{array}{c}\text { Huber stock } * 1 \\
\text { this paper }\end{array}$ & $\begin{array}{c}\text { Huber stock *2 } \\
\text { Korbel (1991) }\end{array}$ & Hawthorne $(1976)^{*}$ \\
\hline $\mathrm{a}[\AA]$ & $8.973(3)$ & $8.961(8)$ & $8.937(1)$ \\
\hline b [̊̊] & $10.063(3)$ & $10.028(9)$ & $9.996(2)$ \\
\hline$c[\AA]$ & $10.334(4)$ & $10.329(14)$ & $10.278(2)$ \\
\hline $\mathrm{V}\left[\AA^{3}\right]$ & 933.11 & 928.17 & 919.18 \\
\hline
\end{tabular}

* data transformation to the standard setting

*1 scorodite associated with kaňkite;

*2 compact porous aggregates of yellow green colour

A quantitative chemical analysis was obtained for a coarsely crystalline scorodite aggregate associated with $\mathrm{Bi}$ arsenates (Table 45). This material is dominantly Fe-, and As-rich, with a very low content of $\mathrm{Al}$ and $\mathrm{P}$. The empirical formula on the basis of $6(\mathrm{O}, \mathrm{OH})$ is

$\left(\mathrm{Fe}_{0.95} \mathrm{Al}_{0.04}\right)_{\Sigma 0.99}\left[\left(\mathrm{AsO}_{4}\right)_{0.99}\left(\mathrm{PO}_{4}\right)_{0.01}\right]_{\Sigma 1.00} \cdot 4.00 \mathrm{H}_{2} \mathrm{O}$.

Table 45 Chemical composition of scorodite (in wt. \%)

\begin{tabular}{|l|rr|}
\hline & Krásno & $* 1$ \\
\hline $\mathrm{ZnO}$ & 0.16 & \\
$\mathrm{Fe}_{2} \mathrm{O}_{3}$ & 32.61 & 34.60 \\
$\mathrm{Al}_{2} \mathrm{O}_{3}$ & 0.93 & \\
$\mathrm{As}_{2} \mathrm{O}_{5}$ & 49.13 & 49.79 \\
$\mathrm{P}_{2} \mathrm{O}_{5}$ & 0.24 & \\
$\mathrm{SO}_{3}$ & 0.10 & \\
$\mathrm{H}_{2} \mathrm{O}^{*}$ & 15.71 & 15.61 \\
total & 98.88 & 100.00 \\
\hline
\end{tabular}

$* \mathrm{H}_{2} \mathrm{O}$ calculated from the formula $\mathrm{Fe}\left(\mathrm{AsO}_{4}\right) .2 \mathrm{H}_{2} \mathrm{O}$.

$* 1$ composition calculated from the ideal formula $\mathrm{Fe}\left(\mathrm{AsO}_{4}\right) \cdot 2 \mathrm{H}_{2} \mathrm{O}$. 


\section{Silver Ag}

The first notes on silver occurrence at Horní Slavkov come from the $16^{\text {th }}$ century. Pavlů (1984) described the presence of wire silver in association with supergene copper minerals on the surface of a corroded ore veinlets in samples from the Huber stock.

During this study, silver has been confirmed in association with covellite, and the oldest generation of black olivenite. Fine dendritic aggregates of silver, up to $1 \mathrm{~mm}$ in size, occured on the surface of dark blue, finely crystalline crusts of covellite with a steal lustre. These crusts fill cavities in quartz and carry relics of primary minerals such as chalcopyrite. Silver was formed by the cementation process, via reaction of mineralizing solutions on the surface of primary minerals, mainly chalcopyrite and arsenopyrite.

\section{Torbernite $\mathrm{Cu}\left(\mathrm{UO}_{2}\right)_{2}\left(\mathrm{PO}_{4}\right)_{2} \cdot 10-12 \mathrm{H}_{2} \mathrm{O}-$ metatorbernite $\mathrm{Cu}\left(\mathrm{UO}_{2}\right)_{2}\left(\mathrm{PO}_{4}\right)_{2} \cdot 8 \mathrm{H}_{2} \mathrm{O}$}

Attractive specimens carrying emerald green tabular (Fig. 69) and barrel-shaped (Fig. 70) crystals of torbernite are mentioned from the old mine of Emperor Josef and other locations in the Krásno ore district by Kratochvil (1957-1964), with reference to a chemical analysis and a measurement of pleochroism. Torbernite is often described in association with gummite and uraninite. Drozen (1967) described this mineral as very rare flakes of a characteristic green colour. However, none of the existing descriptions is supported by X-ray data. Thus it is possible, that the older descriptions relate in fact to metatorbernite, which is confirmed by the present study. Alternatively, it is possible that the original torbernite transformed spontaneously to metatorbernite during the prolonged storage.

Metatorbernite was newly identified in several specimens collected at the Huber stock.

In all cases, metatorbernite forms inconspicuous powdery particles or coatings along fractures in quartz gangue, in association with clay minerals, scorodite and other supergene minerals. X-ray powder diffraction was used for distinguishing this mineral from similar torbernite; its refined unit-cell parameters (Table 46) compare closely with the published data.

Tab le 46 Unit-cell parameters of metatorbenite (for tetragonal unit-cell $P 4 / n)$

\begin{tabular}{|l|cc|}
\hline & $\begin{array}{c}\text { Huber stock *1 } \\
\text { this paper }\end{array}$ & $\begin{array}{c}\text { synt. } \\
\text { Locock }- \text { Burns (2003) }\end{array}$ \\
\hline $\mathrm{a}[\AA]$ & $6.9737(8)$ & $6.9756(5)$ \\
$\mathrm{c}[\AA]$ & $17.3367(8)$ & $17.349(2)$ \\
$\mathrm{V}\left[\AA^{3}\right]$ & 843.13 & 844.18 \\
\hline
\end{tabular}

Fig. 69 Tabular crystal of metatorbernite. Krásno. Width of photo $6 \mathrm{~mm}$. Nicon SMZ1500 microphotography (J. \& E. Sejkora).

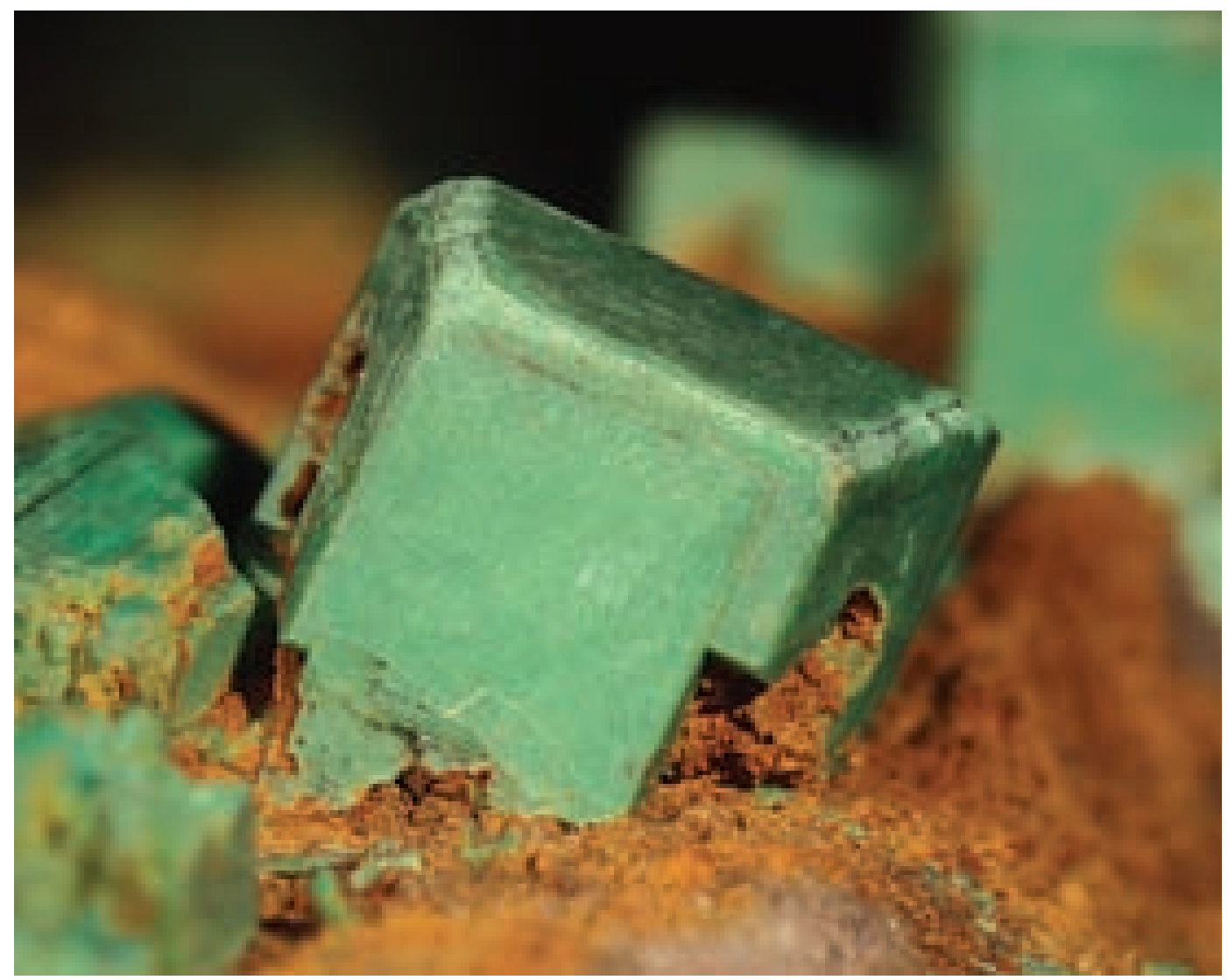




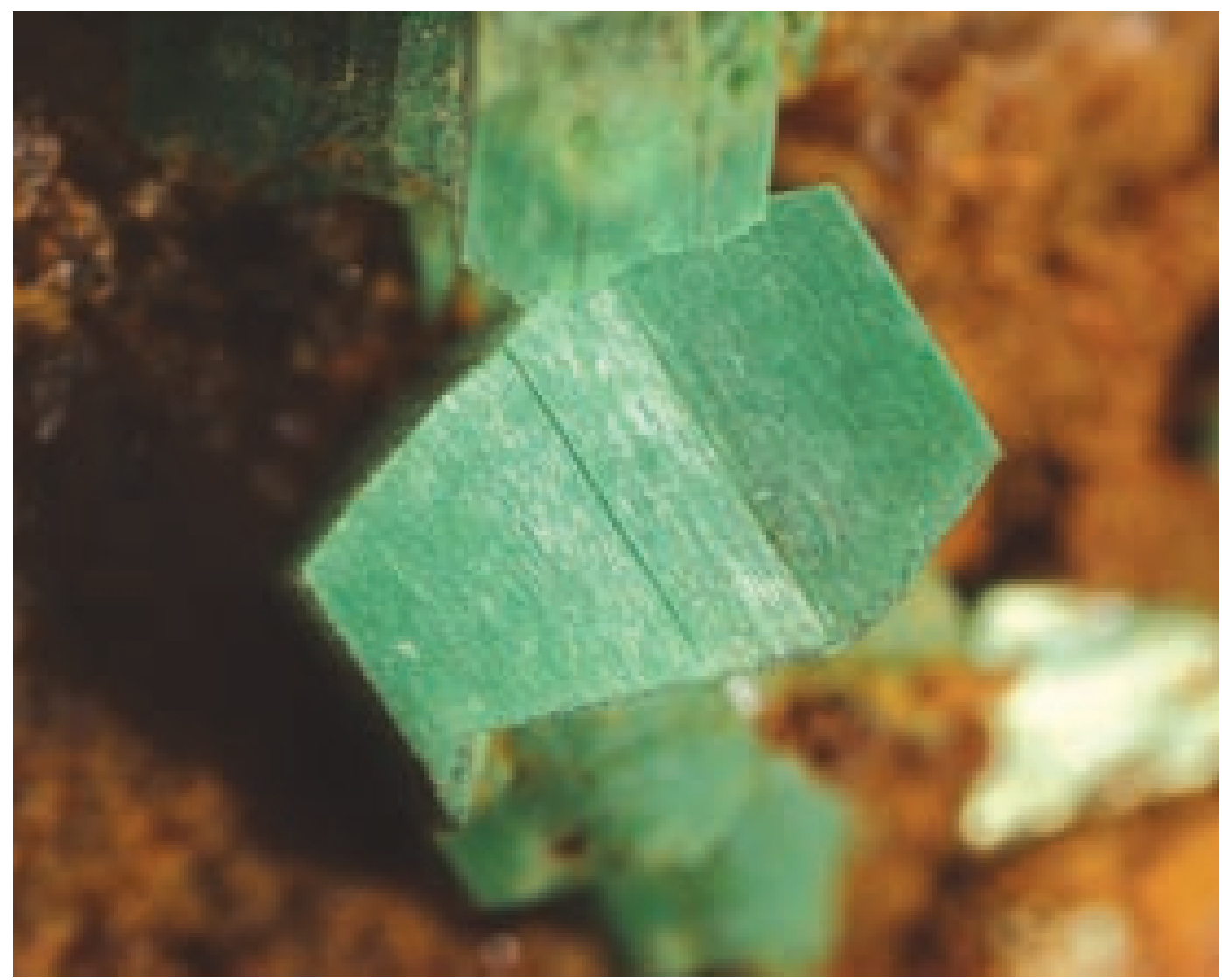

Fig. 70 Barrel-shaped crystal of metatorbernite. Krásno. Width of photo $4 \mathrm{~mm}$. Nicon SMZ1500 microphotography (J. \& E. Sejkora).

\section{Varlamoffite $(\mathrm{Sn}, \mathrm{Fe})(\mathrm{O}, \mathrm{OH})_{2}=$ hydrated Fe-bearing cassiterite}

This material occurs as yellow green, yellow, yellow brown to orange powdery fillings of cavities, coating along fractures and in pores of weathered greisen always in proximity of corroded primary cassiterite. The most common association includes primary cassiterite, apatite, clay minerals and olivenite and varlamoffite formed by a prolonged hy-

Table 47 Chemical composition of "varlamoffite” from Krásno (wt. \%)

\begin{tabular}{|l|rc|}
\hline & mean & range (3 analyses) \\
\hline $\mathrm{Na}_{2} \mathrm{O}$ & 0.03 & $0.01-0.04$ \\
$\mathrm{CaO}$ & 0.19 & $0.00-0.37$ \\
$\mathrm{PbO}$ & 0.06 & $0.00-0.11$ \\
$\mathrm{CuO}$ & 0.06 & $0.05-0.07$ \\
$\mathrm{MnO}$ & 0.04 & $0.02-0.07$ \\
$\mathrm{Fe}_{2} \mathrm{O}_{3}$ & 6.10 & $5.71-6.48$ \\
$\mathrm{Al}_{2} \mathrm{O}_{3}$ & 0.44 & $0.41-0.47$ \\
$\mathrm{Sc}_{2} \mathrm{O}_{3}$ & 0.09 & $0.02-0.16$ \\
$\mathrm{Bi}_{2} \mathrm{O}_{3}$ & 0.06 & $0.04-0.07$ \\
$\mathrm{SnO}_{2}$ & 90.12 & $89.59-90.64$ \\
$\mathrm{SiO}_{2}$ & 0.18 & $0.14-0.22$ \\
$\mathrm{As}_{2} \mathrm{O}_{5}$ & 0.46 & $0.35-0.58$ \\
$\mathrm{SO}_{3}$ & 0.02 & $0.00-0.03$ \\
$\mathrm{H}_{2} \mathrm{O}^{*}$ & 1.37 & $1.30-1.45$ \\
total & 99.20 & \\
\hline
\end{tabular}

* $\mathrm{H}_{2} \mathrm{O}$ content was calculated from charge balance. dration of cassiterite. The X-ray powder diffraction pattern features a strong diffusion of reflections caused by poor crystallinity. Varlamoffite, although reported from numerous localities, is not considered at present a valid mineral species, but a Fe-bearing, hydrated variety of cassiterite.

Chemical analysis has been obtained on yellow brown powdery varlamoffite (Table 47) in association with minerals of the mansfieldite - scorodite series. Its composition corresponds to the empirical formula $\left(\mathrm{Sn}_{0.86} \mathrm{Fe}_{0.11} \mathrm{Al}_{0.01}\right)_{\Sigma 0.98}\left[\mathrm{O}_{1.78}(\mathrm{OH})_{0.22}\right]_{\Sigma 2.00}$. In difference to majority of published analyses of this mineral (Taylor et al. 1970, Sharko 1970, Rezek 1987, Sidorenko et al. 1993 ) the analyzed varlamoffite from Krásno contains low $\mathrm{Fe}$ and $\mathrm{H}_{2} \mathrm{O}$, but the quantities of these additional components are significantly higher than in primary cassiterite (Losos - Beran 2004).

\section{Zavaritskite BiOF}

It has been found in association with native $\mathrm{Bi}$, preisingerite, and bismutite in the Huber open pit, and as an admixture in bismutite at the $4^{\text {th }}$ level of the Huber mine. It is a major component of grey black or black aggregates in fine-grained quartz and rimmed by yellow coatings of late russellite. Intergrowths of zavaritskite, bismutite and preisingerite rimming grains of primary native $\mathrm{Bi}$ were observed in a polished section. 
X-ray powder diffraction pattern of zavaritskite shows that the sample is a mixture of several minerals. Diffractions free of coincidence with the other phases present have been used for refinement of the unit-cell parameters of zavaritskite. The refined unit-cell parameters are in good agreement with the data published for this mineral (Table 48). The quantitative chemical analysis of zavaritskite (Table 49) shows fluorine deficiency, if compared with the theoretical formula BiOF. Fluorine can be replaced by chlorine, but in the analyzed sample $\mathrm{Cl}$ was below the detection limit of c. 0.03 wt. $\% \mathrm{Cl}$. Part of F is

Ta b le 48 Unit-cell parameters of zavaritskite (for tetragonal space group P4/nmm)

\begin{tabular}{|l|lcc|}
\hline & \multicolumn{1}{|c}{$\begin{array}{c}\text { Krásno } \\
\text { this paper }\end{array}$} & $\begin{array}{c}\text { Krásno } \\
\text { Sejkora (1992) }\end{array}$ & $\begin{array}{c}\text { synt } \\
\text { Aurivillius (1964) }\end{array}$ \\
\hline $\mathrm{a}[\AA]$ & $3.7455(7)$ & $3.7468(2)$ & $3.7469(5)$ \\
$\mathrm{c}[\AA]$ & $6.218(2)$ & $6.227(2)$ & $6.226(1)$ \\
$\mathrm{V}\left[\AA^{3}\right]$ & 87.23 & 87.42 & 87.41 \\
\hline
\end{tabular}

Table 49 Chemical composition of zavaritskite

\begin{tabular}{|l|rrr|}
\hline & mean $1 *$ & range*1 & $* 2$ \\
\hline $\mathrm{Bi}$ & 87.85 & $86.98-89.15$ & 85.65 \\
$\mathrm{~F}$ & 6.56 & $5.66-7.09$ & 7.79 \\
$\mathrm{O}^{*}$ & 6.72 & $6.66-6.82$ & 6.56 \\
$\mathrm{H}_{2} \mathrm{O} * *$ & 1.59 & & \\
total & 102.73 & & 100.00 \\
\hline
\end{tabular}

* O content calculated from stoichiometry

$* \mathrm{H}_{2} \mathrm{O}$ content calculated from the formula $\mathrm{BiO}(\mathrm{F}, \mathrm{OH})$ and charge balance.

* 1 mean and range of 3 spot analyses

*2 composition calculated from ideal formula BiOF.

substituted by the $(\mathrm{OH})$ group $-(\mathrm{OH})$ content is 0.10 $0.30 \mathrm{pfu}$. Dolomanova et al. (1962) reported zavaritskite with c. $0.20 \mathrm{pfu}(\mathrm{OH})$ from the Sherlovaya Gora location. The empirical formula for zavaritskite from Krásno is $\mathrm{Bi}_{1.00} \mathrm{O}_{1.00}\left[\mathrm{~F}_{0.82}(\mathrm{OH})_{0.18}\right]_{\Sigma 2.00}$.

\section{Apendix - Phyllosilicates identified in the association of supergene minerals}

Phyllosilicates or so-called "clay minerals" belong to the most common supergene minerals in the whole ore district and they accompany majority of other supergene minerals. Early mineralogical descriptions report the presence of "clay minerals" (dickite, kaolinite, nacrite, smectite) usually without any X-ray powder diffraction and chemical identification. "Clay minerals" usually represent mixtures and cannot be identified by megascopic observation. The present study resulted in reliable identification of several phyllosilicates, characterized in the following text.

\section{Kaolinite $\mathrm{Al}_{2} \mathrm{Si}_{2} \mathrm{O}_{5}(\mathrm{OH})_{4}$}

The sample studied has been collected in the Huber open pit. Kaolinite forms soft beige white pseudomorphs after partly altered carpholite, in $1 \mathrm{~cm}$ thick veinlet and violet fluorite. The mineral probably formed in very late stages of hydrothermal activity. No other clay minerals

Ta b le 50 Unit-cell parameters of kaolinite (for triclinic space group C1)

\begin{tabular}{|l|cc|}
\hline & $\begin{array}{c}\text { Huber open pit } \\
\text { this paper }\end{array}$ & $\begin{array}{c}- \\
\text { Neder } \text { et al. }(1999)\end{array}$ \\
\hline $\mathrm{a}[\AA]$ & $5.154(1)$ & $5.154(9)$ \\
$\mathrm{b}[\AA]$ & $8.926(2)$ & $8.942(4)$ \\
$\mathrm{c}[\AA]$ & $7.400(1)$ & $7.40(1)$ \\
$\alpha\left[^{\circ}\right]$ & $92.63(3)$ & $91.69(9)$ \\
$B\left[^{\circ}\right]$ & $104.58(2)$ & $104.61(5)$ \\
$\gamma\left[^{\circ}\right]$ & $88.54(2)$ & $89.82(4)$ \\
$\mathrm{V}\left[\AA^{\circ}\right]$ & 329.1 & 329.91 \\
\hline
\end{tabular}

accompany kaolinite. Kaolinite was identified by X-ray powder diffraction. Refined unit-cell parameters (Table 50) are in good agreement with the published data.

\section{Dickite $\mathrm{Al}_{2} \mathrm{Si}_{2} \mathrm{O}_{5}(\mathrm{OH})_{4}$}

Dickite identified in specimens from the Huber stock forms whitish crystalline aggregates, up to several $\mathrm{cm}^{2}$ in size, consisting of tabular crystals up to $0.1 \mathrm{~mm}$, in cavities of quartz gangue (Fig. 71). It is associated with minerals of the crandallite group and supergene $\mathrm{Cu}$ minerals. At the $4^{\text {th }}$ level of the Huber shaft it forms accumulations several $\mathrm{cm}$ across with probably primary libethenite and fluorite. The aggregates of intensive yellow green colour (Fig. 72) are distinctly crystalline with imperfect tabular crystals to $0.2 \mathrm{~mm}$. The striking colour of dickite is probably caused by finely dispersed libethenite. Dickite was identified by X-ray powder diffraction.

\section{Cookeite $\mathrm{LiAl}_{4} \mathrm{Si}_{3} \mathrm{AlO}_{10}(\mathrm{OH})_{8}$}

Cookeite sample was collected at the $4^{\text {th }}$ level of the Huber shaft, in a central part of the Huber stock (Košatka 1988). It forms grey compact aggregates occurring in a cassiterite nest, where it fills space between grains of topaz and cassiterite. It has been identified by X-ray powder diffraction in a sample representing a mixture with dickite. The qualitative spectral analysis is given in Table 51.

Table 51 Spectral analysis of cookeite, Huber stock, Krásno (in wt. \%)

\begin{tabular}{|cccc|}
\hline$>1 \%$ & $1-0.1 \%$ & $0.1-0.01 \%$ & $<0.01 \%$ \\
\hline $\mathrm{Al}, \mathrm{Si}, \mathrm{Ca}, \mathrm{Li}$ & $\mathrm{Mn}, \mathrm{Mg}, \mathrm{Fe}$, & $\mathrm{K}, \mathrm{B}, \mathrm{Ti}, \mathrm{P}$, & $\mathrm{Be}, \mathrm{As}, \mathrm{Ga}, \mathrm{Sr}$, \\
& $\mathrm{Na}, \mathrm{Sn}$ & $\mathrm{Zn}, \mathrm{Cu}$ & $\mathrm{Zr}, \mathrm{Cr}, \mathrm{Ni}$ \\
\hline
\end{tabular}




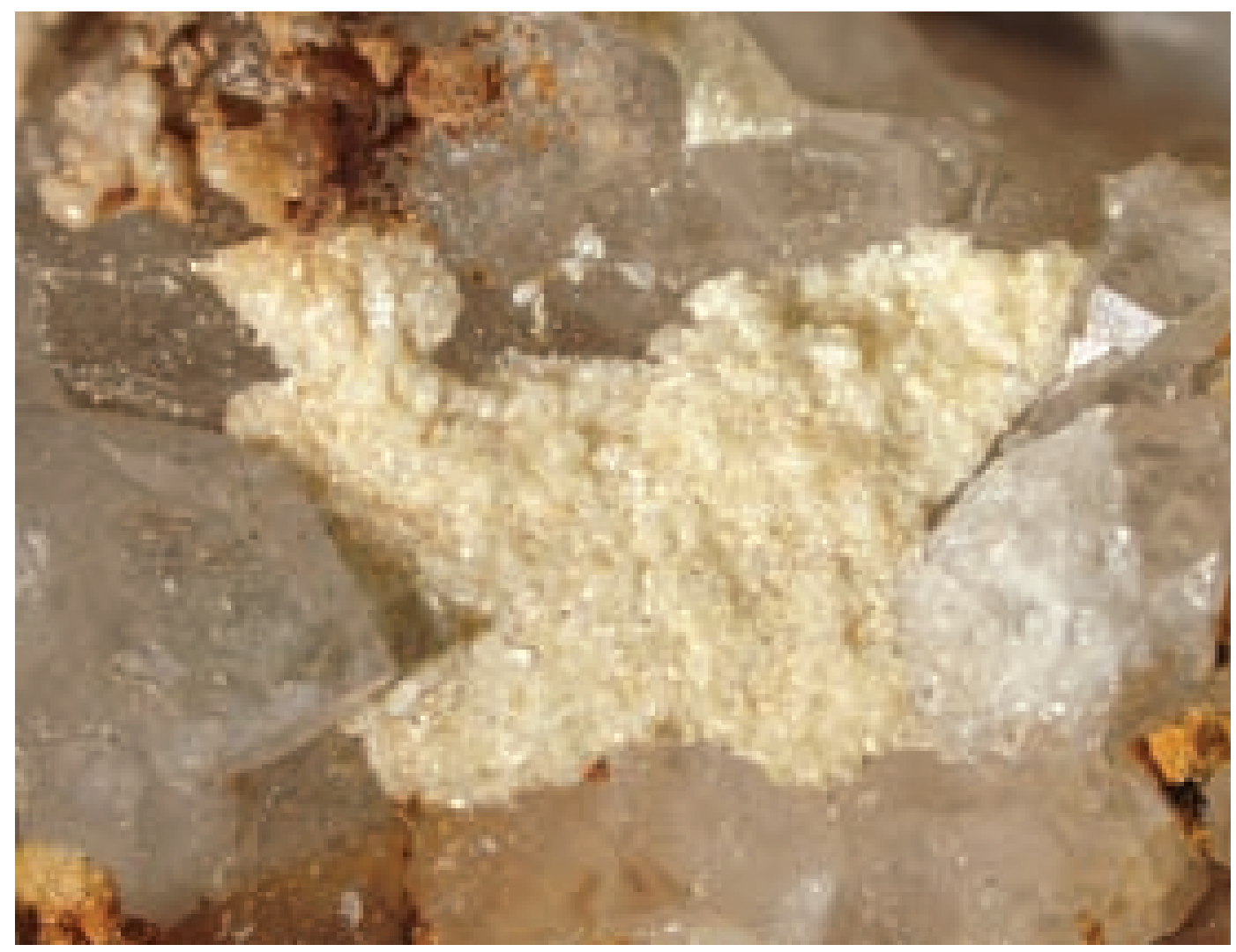

Fig. 71 Crystalline dickite aggregates in cavities of quartz gangue. Huber open pit, Krásno. Width of photo $9 \mathrm{~mm}$. Nicon SMZ1500 microphotography (J. \& E. Sejkora).

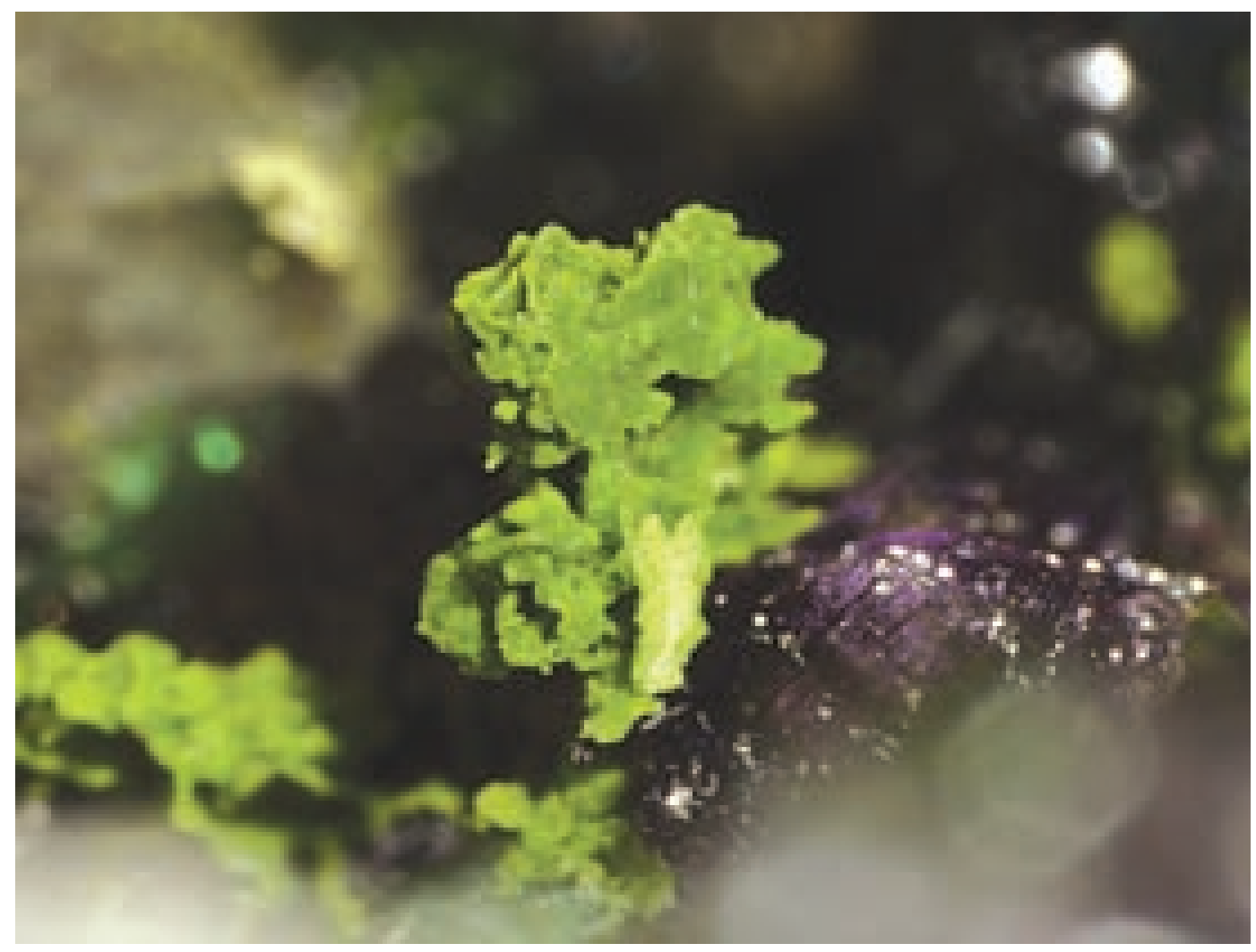

Fig. 72 Bright yellow green dickite aggregates associated with libethenite, $4^{\text {th }}$ level of the Huber mine, Krásno. Width of photo $3 \mathrm{~mm}$. Nicon SMZ1500 microphotography (J. \& E. Sejkora). 


\section{Evolution of the supergene mineral associations in the Huber and Schnöd stocks}

The processes of formation of supergene mineralization in the Sn-W ore district Krásno can be divided into three main stages. The stages are not strictly separated in space and time:

1. Late hydrothermal activity

2. Supergene processes

3. Recent and sub-recent processes

Late hydrothermal activity produced aggregates of zavaritskite, bismite, bismutite, presingerite, petitjeanite etc., derived by alteration of native bismuth. This type of hydrothermal alteration is known from number of other localities (Sejkora 1992, Ondruš et al. 1994). The libethenite - fluorite - dickite accumulations found at the Huber stock and of some scorodite types there probably formed in the process of late hydrothermal alteration, as well as kaolinite replacing carpholite.

Large accumulations of the primary phosphates, i.e., triplite and apatite, were a dominant source for formation of supergene minerals in the supergene processes. Consenquently, a large part of the supergene minerals are phosphates (see also Sejkora et al. 2006b). The sulpharsenides and sulphides (arsenopyrite, chalcopyrite, chalcocite etc.) are the second important source, producing mainly arsenates and sulphates. The rarity of supergene carbonates closely correlates with rarity of primary carbonates in the whole deposit, $\mathrm{CO}_{2}$ in minor supergene carbonates is obviously of atmospheric origin.

Various mechanisms participated on the decomposition of the primary sulpharsenides and sulphides during supergene processes. They included, in addition to natural supergene processes, alterations triggered by mining activity, which was taking place for several centuries. It induced weathering on a large scale, resulting in formation of sub-recent or recent arsenates and sulphates in general and iron arsenates in particular. The latest alterations resulted in a sequence scorodite - pharmacosiderite - arseniosiderite, terminated by a final formation of $l i$ monite. A wide range of the supergene copper minerals, from the early sulphates through arsenates and phosphates to the latest carbonates and silicates suggests relatively widespread presence of small amounts of chalcopyrite and other primary $\mathrm{Cu}$-bearing minerals and continous elevated activity of $\mathrm{Cu}$. Native silver formed by the process of cementation from products of decomposition of the primary sulphides, which contain minor amounts of silver. Because macroscopic primary silver minerals at Krásno are unknown, silver was present either as minor inclusions of primary silver-bearing minerals in other sulphides, or as an isomorphose admixture in copper minerals (djurleite, stannoidite and chalcopyrite). The latter alternative is considered more probable. Similar cementation processes resulted in the formation of native cooper and covellite.

Conditions of formation of secondary cassiterite (varlamoffite - remobilized microcrystalline variety of cassiterite) are interesting. Cassiterite was obviously the source of Sn. Unlike primary cassiterite, varlamoffite was never observed in proximity of $\mathrm{Sn}$ sulphides in various stages of weathering. This indicates that the mechanism of dissolution and crystallization of $\mathrm{SnO}_{2}$ is not dependent on the presence of sulphides and on $\mathrm{pH}$ gradient. It seems that varlamoffite has been formed by local dissolution of cassiterite by solutions rich in F- ion. Dissolved $\mathrm{SnO}_{2}$, after transport for a distance of several mm, was precipitated from solutions containing relatively mobile ions $\left[\mathrm{Sn}(\mathrm{F}, \mathrm{OH})_{4}\right]^{-}$.

Decomposition of arsenopyrite and other sulphides resulted in formation of abundant recent and sub-recent arsenates and sulphates of copper and iron. Younger generations of pharmacosiderite and scorodite, formed by recent spontaneous precipitation, are characteristic by striking colour variation of their crusts and coatings. Arseniosiderite represents the very late stage of decomposition of arsenates, being succeeded only by formation of limonite. Chalcanthite, brochantite or native copper, precipitated in old adits, belong to typical examples of sub-recently formed minerals. The occurrences of subrecent chalcanthite indicate relatively high local concentrations of copper and a high acidity of solutions, resulting from a strong alteration of the primary ore minerals.

Acknowledgements. The authors gratefully acknowledge cooperation of Jiř́i Litochleb (National Museum, Prague), Stanislav Vrána (Czech Geological Survey, Prague), Milan Rieder (Technical University, Ostrava) and numerous colleagues who kindly provided samples for this study Anna Sabová (Květná), Ctibor Süsser (Sokolov), Jaromír Tvrdý (Karlovy Vary), Pavel Černý (Př́ibram), Pavel Němec (Havírov) and others. This work was supported by Grants from the Ministery of Culture of the Czech Republic (Project MK00002327201) and the Granting Agency of the Czech Republic (Grant No. 205/03/D004).

Submitted August 24, 2006

\section{References}

Anthony, J. W. - Bideaux, R. A. - Bladh, K. W. - Nichols, M. C. (2000): Handbook of mineralogy. Volume IV. Arsenates, phosphates, Vanadates. - 680 pp., Mineral Data Publishing. Tucson, USA.

Artl, T. - Armbruster, T. (1999): Single-rystal X-ray structure refinement of cornwallite, $\mathrm{Cu}_{5}\left(\mathrm{AsO}_{4}\right)_{2}(\mathrm{OH})_{4}$ : A comparison with its polymorph cornubite and the $\mathrm{PO}_{4}$-analogue pseudomalachite. $-\mathrm{N}$. Jb. Miner. Mh.; $10,468-480$

Aurivillius, B. (1964): The crystal structure of bismuth oxide fluoride. II. A refinement of the previously published structure. - Acta Chem. Scand.; 18, 1823-1830.

Beran, P. (1999): Nerosty cíno-wolframových ložisek Slavkovského lesa (Minerals of tin-tungsten deposits from Slavkovský les area). - Regional museum and library in Sokolov. Sokolov, 287 pp. (in Czech).

Beran, P. - Sejkora, J. (2006): The Krásno Sn-W ore district near Horní Slavkov: mining history, topographical, geological and mineralogical characteristics. - Journ. Czech Geol. Soc., 51: 3-42

Braithwaite, R. S. W. (1983): Infrared spectroscopic analysis of the olivenite-adamite series, and a phosphate substitution in olivenite. Mineral. Mag.; 47, 51-57. 
Breithaupt, A. (1849): Die Paragenesis der Mineralien. - Verlag von J. G. Engelhardt, Freiberg.

Buerger, M. J. - Dollase, W. A. - Garaycochea-Wittke, I. (1967): The structure and composition of the mineral pharmacosiderite. - Zeit. Krist.; 125, 92-108.

Burnham, Ch. W. (1962): Lattice constant refinement. - Carnegie Inst. Washington Year Book 61: 132-135.

Burns, P. C. - Hawthorne, F. C. (1995): Rietveld refinement of the crystal structure of olivenite: a twinned monoclinic structure. - Can. Mineral.; 33, 885-888.

Burns, P. C. - Smith, J. V. - Steele, I. M. (2000): Arizona porphyry copper/hydrothermal deposits I. The structure of chenevixite nad luetheite. - Mineral. Mag.; 64, 4, 25-30.

Čech, F. - Jansa, J. - Novák, F. (1976): Kaňkite, $\mathrm{FeAsO}_{4} \cdot 3.5 \mathrm{H}_{2} \mathrm{O}$, a new mineral. - N. Jb. Miner. Mh.; 426-436.

Dolomanova. Y. I. - Sendorova, V. M. - Yanchenko, M. T. (1962): Zavaritskite (BiOF), a new oxifluoride mineral. - Doklady Acad. Nauk SSSR, Ser. geol.; 146, 680-682. (in Russian).

Drozen, J. (1967): Geologické poměry ložiska Hubský peň, Výroční zpráva za rok 1966. - (Annual report for 1966, project "Geology of the Huber stock deposit"). - Nepublik. zpr., Rudné doly n.p. Příbram, Geofond Praha P22656. (in Czech).

Fjellvag, H. - Gronvold, F. -Stolen, S. -Andresen, A. F. -Mueller-Kaefer, R. - Simon, A (1988): Low-temperature structural distortion in CuS. Zeit. Krist.; 184, 111-121.

Glückseling, A. M. (1862): Das Vorkommen der Mineralien im Egere Kreise Böhmens. - Versammlung deutscher Ntfr. und Ärzte, Karlsbad.

Golic, L. - Graunar, M. - Lazarini, F. (1982): Catena-di-mue-hydroxomue3-oxo-dibismuth(III) sulfate. - Acta Cryst.; B38, 2881-2883

Grice, J. D. (2002): A solution to the crystal structures of bismutite and beyerite. - Can. Mineral.; 40, 693-698.

Hawthorne, F. C. (1976): Hydrogen positions in scorodite. - Acta Cryst.; B32, 2891-2892.

Hawthorne, F. C. - Groat, L. E. - Eby, R. K. (1989): Antlerite, $\mathrm{Cu}_{3} \mathrm{SO}_{4}(\mathrm{OH})_{4}$, a heteropolyhedral wallpaper structure. - Can. Miner., 27: 205-209.

Hodge, L. C. (1970): Russellite: a second occurrence.-Miner. Mag., 37 : 705-707.

Hoffmann, J. (1903): Historisch - mineralogische Skizze von Schlaggenwald. - Programm der k. u k. Staatsrealschule in Elbogen 1903, Loket.

Klvaňa, J. (1886): Nerosty království Českého. - (Minerals of the Kingdom of Bohemia). - Uherské Hradiště. (in Czech).

Kniep, R. - Mootz, D. - Vegas, A. (1977): Variscite. - Acta Cryst.; B33, 263-265.

Knight, K. S. (1992): The crystal structure of russelite; a re-determination using neutron powder diffraction of synthetic $\mathrm{Bi}_{2} \mathrm{WO}_{6}$. - Miner. Mag.; 56, 399-409.

Kolitsch, U. - Slade, P. G. - Tiekink, E. R. T. - Pring, A. (1999): The structure of antimonian dussertite and the role of antimony in oxysalt minerals. - Miner. Mag.; 63, 17-26.

Korbel, P. (1991): Supergene minerals from Horní Slavkov. - Sbor. Nár. Muz. (Praha); B 47, 1-4, 1-24.

Košatka, M. (1988): Geologická situace centrální části Huberova pně na ložisku Krásno (Geological situation of central part of Hubs' stock in Krásno deposit). - Msc. these, Faculty of Science, Charles University, Prague. (in Czech).

Kratochvíl, J. (1957-1964): Topografická mineralogie Čech VI (S-T). [Topographic mineralogy of Bohemia VI (part S-T)]. - Nakladatelství ČSAV Praha. (in Czech).

Krejčí, J. (1855): O prahorách českých. - (On ancient rock formations in Bohemia). - Živa, 3, Praha. (in Czech).

Locock, A. J. - Burns, P. C. (2003): Crystal structures and synthesis of the copper-dominant members of the autunite and meta-autunite groups: torbernite, zeunerite, metatorbernite and metazeunerite. - Can. Mineral., 41: 489-502.

Losos, Z. - Beran, A. (2004): OH defects in cassiterite. - Mineral. Petrol., 81: 219-234.
Mach, Z. (1979): Chalkosiderit a Barium-farmakosiderit z Krásna u Horního Slavkova. (Chalcosiderite and Barium-pharmacosiderite from Krásno near Horní Slavkov). - Čas. Mineral. Geol., 79: 90-91 (in Czech).

Mach, Z. - Korbel, P. (1990): Sekundární minerály z Huberova pně u Krásna u Horního Slavkova. - (Secondary minerals from the Huber stock at Krásno near Horní Slavkov). - Příroda Karlovarska I., Karlovarské muzeum v Karlových Varech. (in Czech).

Mellini, M. - Merlino, S. (1979): Posnjakite, $\left(\mathrm{Cu}_{4}(\mathrm{OH})_{6}\left(\mathrm{H}_{2} \mathrm{O}\right) \mathrm{O}\right)$ octahedral sheets in its structure. - Zeit. Krist.; 149, 249-257.

Menchetti, S. - Sabelli, C. (1976): Crystal chemistry of the alunite series: crystal structure refinement of alunite and synthetic jarosite. $-\mathrm{N}$. Jb. Miner. Mh.; 406-417.

Mereiter, K. - Preisinger, A. (1986): Kristallstrukturdaten der Wismutminerale Atelestit, Mixit und Pucherit. - Öster. Akad, Wissen., Math.-Naturwissen. Klasse, Sitzungsberichte, 123: 79-81.

Merlino, S. - Perchiazzi, N. - Franco, D. (2003): Brochantite, $\mathrm{Cu}_{4} \mathrm{SO}_{4}(\mathrm{OH})_{6}$ : OD character, polytypism and crystal structures. - Eur. J. Miner.; 15, 267-275.

Moore, P. B. - Ito, J. (1974): I. Jahnsite, segelerite, and robertsite, three new transition metal phosphate species. II. Redefiniton of overite, an isotype of segelerite. III. Isotypy of robertsite, mitridatite and arseniosiderite. - Amer. Mineral.; 59, 48-59.

Mrázek, Z. (1981): Crandallit a mixit z Horního Slavkova. (Crandallite and mixite from Horní Slavkov). - Sbor. Vys. šk. chem. techn., G20, 43-47. (in Czech).

Mutter, G. - Eysel, W. - Greis, O. - Schmetzer, K. (1984): Crystal chemistry of natural and ion-exchanged pharmacosiderites. $-\mathrm{N}$. Jb. Miner. Mh., 4, 183-192.

Natta, G. - Baccaredda, M. (1933): Tetrossido di antimonio e antimoniati. - Zeit. Krist., 85:, 271-296.

Neder, R. B. - Burghammer, M. - Grasl, T. - Schulz, H. - Bram, A. Fiedler, $S$. (1999): Refinement of the kaolinite structure from singlecrystal synchrotron data. - Clays and Clay Minerals; 47, 487-494.

Ondruš, P. (1993): ZDS - A computer program for analysis of X-ray powder diffraction patterns. - Materials Science Forum, 133-136: 297300, EPDIC-2. Enchede.

Ondruš, P. - Jansa, J. - Novák, F. - Vavř́n, I. (1994): Origin and relationships of bismuth secondary minerals at the Moldava deposit in the Krušné hory Mts. - Věst. Čes. geol. Úst., 69: 79-86.

Ondruš, P. - Skála, R. (1997): New quasi-emirical channel Search/Match algorithm for ICDD PDF2 Database: A tool for qualitative phase analysis integrated in the ZDS-System software package for X-ray powder diffraction analysis - Fifth European Powder Diffraction Conference EPDIC-5, 193. Parma.

Pavlio, D. (1984): Djurleite and stanoidite from the tin-tungsten deposit at Krásno nad Teplou (Czechoslovakia). - Věst. Ústř. Úst. geol., 59: 351-354.

Peacor, D. R. - Dunn, P. J. (1985): Sodium-pharmacosiderite a new ana$\log$ of pharmacosiderite from Australia and new occurrences of Barium-pharmacosiderite. - Min. Record, 16: 121-124.

Philibert, J. A. (1963): A metod for calculation of the absorption correction in electron probe microanalysis. - In: H. R. Petee - V. E. Colser - A. Engstrom (edit.): X-ray Optics and X-ray Microanal. Academic Prew., New York, London.

Pouchou, J. L. - Pichoir, F. (1985): "PAP" procedure for improved quantitative microanalysis. - Microbeam Analysis, 20: 104-105.

Povondra, P. - Ǩidkošil, T. (1980): Brochantit z Piesků a Lubietové u Banské Bystrice (Brochantite from Piesky and Lubietová near Banská Bystrica). - Acta Univ. Carol. - Geol., 1-2, 1-8. Praha (in Czech).

Rae, A. D. - Thompson, J. G. - Withers, R. L. (1991): Structure refinement of commensurately modulated bismuth tungstate $\mathrm{Bi}_{2} \mathrm{WO}_{6}$ - Acta Cryst.; B47, 870-881.

Restori, R. - Schwarzenbach, D. (1986): Charge density in Cuprite, $\mathrm{Cu}_{2} \mathrm{O}$. - Acta Cryst.; B42, 201-208.

Rezek, K. (1987): Varlamoffite from the locality Bajan Obo in Mongolia (Varlamoffit z lokality Bajan Obo v Mongolsku). - Věst. Ústř. Úst. geol, 62: 291-295. (in Czech).

Rodríguez-Carvajal, J. (2005): Computer Program FullProf, ver. December 2005. - Laboratoire Leon Bril-louin (CEA-CNRS), France. 
Rosický, V. (1916): Topaz ze Slavkova v Čechách. - (Topaz from Slavkov in Bohemia). - Rozpr. Čes. Akad., Vědy Sloves. Umění, Tř. II., 25: 7, Praha. (in Czech).

Sabelli, C. (1980): The crystal structure of chalcophyllite. - Zeit. Krist.; 151, 129-140.

Schmetzer, K. - Horn, W. - Bank, H. (1981): Alumopharmakosiderit, $\mathrm{KAl}_{4}\left[(\mathrm{OH})_{4}\left(\mathrm{AsO}_{4}\right)_{3}\right]$. 6,5 $\mathrm{H}_{2} \mathrm{O}$, ein neues Mineral. - N. Jb. Miner. Mh., 3, 97-102.

Sejkora, J. (1992): Mineralogie oxidických fází s bismutem (Mineralogy of oxygen-containing bismuth phases). - Msc. these, 154 pp., Faculty of Science, Charles University, Prague. (in Czech).

Sejkora, J. - Škoda, R. - Ondruš, P. (2006d): New naturally occurring mineral phases from the area Krásno - Horní Slavkov, western Bohemia, Czech Republic. - Journ. Czech Geol. Soc., 51: 159-188

Sejkora, J. - Škoda, R. - Ondruš, P. - Beran, P. - Süsser, C. (2006c): Mineralogy of phosphate accumulations in the Huber stock, Krásno ore district, Slavkovský les area, Czech Republic. - Journ. Czech Geol. Soc., 51: 103-147

Sidorenko, G. A. - Korovushkin, V. V. - Gorshkov, A. I. - Rudnizkaya, E. S. - Dikov, J. P. - Kauchova, L. V. - Sivzov, A. V. (1993): On the mineral nature of varlamoffite. - Miner. Zhurn., 15: 94-101 (in Russian).

Sieber, N. H. W. - Tillmanns, E. - Hofmeister, W. (1987a): Structure of hentschelite, $\mathrm{CuFe}_{2}\left(\mathrm{PO}_{4}\right)_{2}(\mathrm{OH})_{2}$, a new member of the lazulite group. - Acta Cryst.; C43, 1855-1857.

Sieber, N. H. W. - Tillmanns, E. - Medenbach, O. (1987b): Hentschelite, $\mathrm{CuFe}_{2}\left(\mathrm{PO}_{4}\right)_{2}(\mathrm{OH})_{2}$, a new member of the lazulite group, and reichenbachite $\mathrm{Cu}_{5}\left(\mathrm{PO}_{4}\right)_{2}\left(\mathrm{OH}_{4}\right)$, a polymorph of pseudomalachite, two new copper phosphate minerals from Reichenbach, Germany. - Amer. Mineral.; 72, 404-408.

Sharko, E. D. (1970): On the mineral nature and properties of "varlamoffite" (product of stannite oxidation). - Zap. Vsesojuz. miner. Obsch., 99: 232-246.

Shoemaker, G. L. - Anderson, J. B. - Kostiner, E. (1977): Refinement of the crystal structure of pseudomalachite. - Amer. Mineral.; 62, 1042-1048.
Slaviček, P. (1984): Chalkantit z Krásna nad Teplou a z Telnice v Krušných horách. - (Chalcanthite from Krásno nad Teplou and from Telnice in the Krušné hory Mts). - Čas. Mineral. Geol., 84: 316. (in Czech).

Slavik, F. (1903): Nové nálezy minerálů u Slavkova. - (New mineral finds near Slavkov). - Rozpr. Čes. Akad., Vědy Sloves. Umění, Tř. II., 12: 35, Praha. (in Czech).

Stanley, C. J. - Roberts, A. C. - Harris, D. C. - Criddle, A. J. - Szymanski J. T. (1992): Cannonite, $\mathrm{Bi}_{2} \mathrm{O}(\mathrm{OH})_{2} \mathrm{SO}_{4}$, a new mineral from Marysvale, Utah, USA. - Mineral. Mag.; 56, 605-609.

Tacl, A. - Blüml, A. (1974): Mineralogický výzkum sekundárních nerostů ložiska Krásno. - (Mineralogical research of secondary minerals from the Krásno deposit). - Nepublik. zpr., archiv Rudných dolů s.p. Př́ibram. (in Czech).

Taylor, R. G. - Morgan, W. R. - Phillips, D. N. (1970): On the occurrence of varlamoffite at the Sardine tin mine, North Queensland, Australia. - Miner. Mag., 37: 624-628.

Vilminot, S. - Richard-Plouet, M. - Andre, G. - Swierczynski, D. Guillot, M. - Bouree-Vigneron, F. - Drillon, M. (2003): Magnetic structure and properties of $\mathrm{Cu}_{3}(\mathrm{OH})_{4} \mathrm{SO}_{4}$ made of triple chains of spins $\mathrm{s}=1 / 2$. - Journal Solid State Chem.; 170, 255-264.

Yakubovich, O. V. - Mel'nikov, O. K. (1993): Libethenite, $\mathrm{Cu}_{2}\left(\mathrm{PO}_{4}\right)(\mathrm{OH})$ : synthesis, crystal structure refinement, comparative crystal chemistry. - Kristallografiya; 38, 1, 63-70. (in Russian).

Yeh, C. - Lu, Z. W. - Froyen, S. - Zunger, A . (1992): Zinc-blende-Wurtzite polytypism in semiconductors. - Phys. Review, Serie 3.B - Conden. Matter; 46, 10086-10097.

Zepharovich, V. (1857): Mineralogisches Lexikon für das Kaiserthum Österreich, Wien.

Zigan, F.-Joswig, W. - Schuster, H. U.-Mason, S. A. (1977): Verfeinerung der Struktur von Malachit, $\mathrm{Cu}_{2}(\mathrm{OH})_{2} \mathrm{CO}_{3}$, durch Neutronenbeugung. - Zeit. Krist.; 145, 412-426.

Zigan, F. -Schuster, H. D. (1972): Verfeinerung der Struktur von Azurit, $\mathrm{Cu}_{3}(\mathrm{OH})_{2}\left(\mathrm{CO}_{3}\right)_{2}$, durch Neutronenbeugung. - Zeit. Krist.; 135, 416436 .

\section{Supergení minerály ložisek Huberova a Schnödova pně, rudní revír Krásno, Slavkovský les, Česká republika}

V práci jsou shrnuty výsledky studia supergenních minerálů z oblasti Huberova a Schnödova pně v Sn-W rudním revíru Krásno u Horního Slavkova (Slavkovský les, Česká republika). Mineralogický výzkum byl založen na využití optické a elektronové mikroskopie, rentgenové práškové difrakci a elektronové mikroanalýze. Jednotlivé zjištěné minerální druhy jsou včetně zjištěných dat encyklopedicky prezentovány. Diskutována je i role pozdně hydrotermálních, supergenních, sub-recentních a recentních procesů při vzniku jednotlivých minerálů i jejich asociací. 